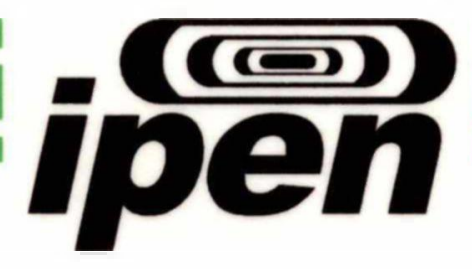

AUTARQUIA ASSOCIADA À UNIVERSIDADE DE SÃO PAULO

\title{
DETERMINAÇÃO DE RESÍDUOS DE HEXACLOROCICLOHEXANO "HCH" NO SORO SANGÜÍNEO DE TRABALHADORES EXPOSTOS NO ARQUIVO HISTÓRICO DE JOINVILLE NA DÉCADA DE 80
}

\section{ELAINE CRISTINA DAMASCENO LOIOLA}

Dissertação apresentada como parte dos requisitos para obtenção do Grau de Mestre em Ciências na Área de Tecnologia Nuclear - Materiais.

Orientador:

Dr. José Oscar Willian Vega Bustillos

São Paulo

2007 


\section{$\frac{((-))}{p e n}$}

INSTITUTO DE PESQUISAS ENERGÉTICAS E NUCLEARES

AUTARQUIA ASSOCIADA À UNIVERSIDADE DE SÃO PAULO

Determinação de resíduos de Hexaclorociclohexano "HCH" no soro sangüíneo de trabalhadores expostos no Arquivo

Histórico de Joinville na década de 80.

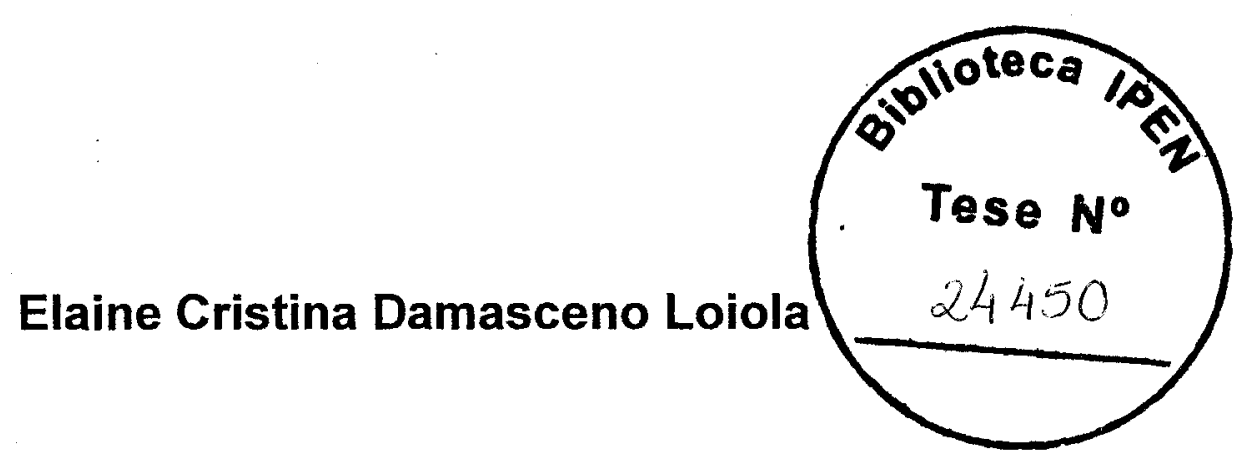

Dissertação apresentada como parte dos requisitos para obtenção do Grau de Mestre em Ciências na Área de Tecnologia Nuclear - Materiais.

Orientador:

Dr. José Oscar William Vega Bustillos 


\section{ipen}

INSTITUTO DE PESQUISAS ENERGÉTICAS E NUCLEARES

AUTARQUIA ASSOCIADA À UNIVERSIDADE DE SÃO PAULO

Determinação de resíduos de Hexaclorociclohexano "HCH" no soro sangüíneo de trabalhadores expostos no Arquivo

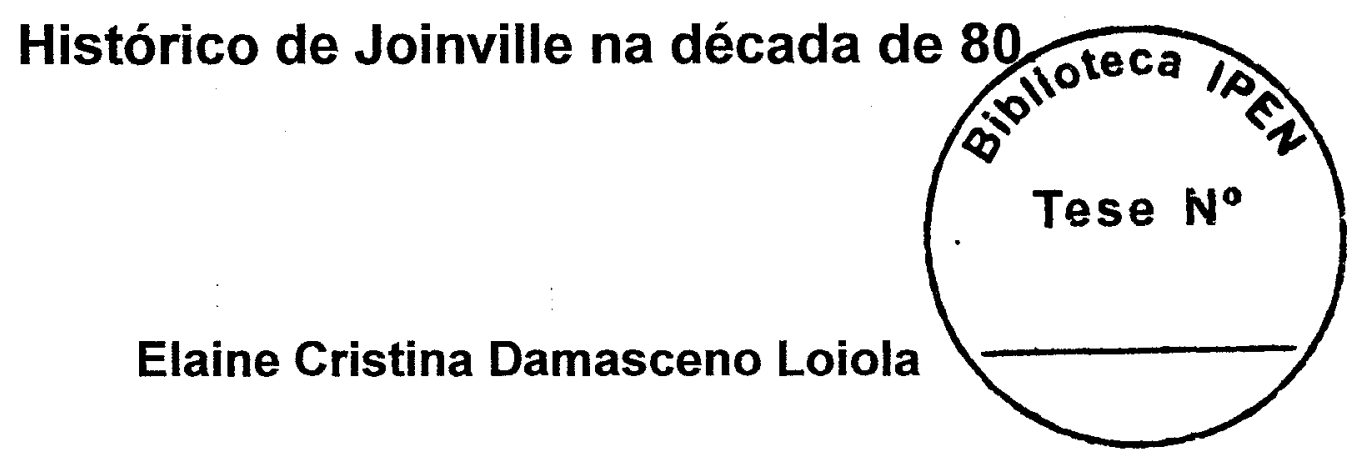

Dissertação apresentada como parte dos requisitos para obtenção do Grau de Mestre em Ciências na Área de Tecnologia Nuclear - Materiais.

Orientador:

Dr. José Oscar William Vega Bustillos 
Dedico esse trabalho a DEUS e a todos os meus Anjos da Guarda, em especial João Damasceno Loiola, meu Pai, que tanto me apoia e a Lucia Joana Loiola, minha mãe, que tanto se dedicou à minha vitória, aos meus irmãos Leni, João Nilson e Cristiano que sempre estiveram ao meu lado, às minhas crianças que são fonte da minha alegria Lucas, Felipe, Tamires, Tiago, Natalia e Ana Carolina. 


\section{AGRADECIMENTOS}

Ao meu orientador Dr. Oscar Vega Bustillos pela amizade, dedicação e aprendizagem.

À Heloisa H. B. Toledo pelo aprendizado, companheirismo, paciência e amizade.

Ao Instituto Adolfo Lutz de São Paulo onde realizei meu estagio e permaneci durante 4 anos e à todos os profissionais da Seção de Pesticida Residual em especial ao Reinaldo Amauri Jr. Pela amizade sincera e pela contribuição nas extrações das amostras.

Ao Instituto de Pesquisas Energéticas e Nucleares - IPEN.

Ao Instituto Oceanográfico - USP.

Ao meu Pai João Damasceno Loiola que batalhou para que os meus estudos nunca fossem interrompidos.

À minha Mãe Lucia Joana Loiola que com tanto amor se tornou a Melhor Mãe do Mundo.

À minha família Leni, Nilton, Lucas, Felipe, Tiago, João Nilson, Juci, Tamires, Natalia, Cristiano, Renata e Ana Carolina que sempre ficaram ao meu lado.

À SFDK pelo incentivo na reta final e disponibilidade de tempo.

À PhD. Maria Luiza Passanezi Araujo Gomez, pela dedicação de revisar todo o meu trabalho e pela amizade.

À todos que convivi no decorrer da minha aprendizagem. 
"Somos tudo aquilo que acreditamos ser"

(Autor Desconhecido) 


\section{Determinação de resíduos de Hexaclorociclohexano " $\mathrm{HCH}$ " no soro sangüíneo de trabalhadores expostos no Arquivo Histórico de Joinville na década de 80.}

\section{Elaine Cristina Damasceno Loiola}

\section{RESUMO}

O Hexaclorociclohexano $(\mathrm{HCH})$ é um inseticida do grupo dos organoclorados, composto por uma mistura de isômeros formados durante a sintese química, através de sucessivas adições de cloro ao benzeno. Estes isômeros podem contaminar não só o meio ambiente como também a população que tenha contato direto ou indireto com os resíduos. Nas décadas de 70 e 80 , foi utilizado um produto comercial composto pelo ativo $\mathrm{HCH}$ comercializado como "Hexabel@" no controle de insetos xilófagos no Acervo Histórico de Joinville em Santa Catarina. A aplicação do inseticida foi realizada pelos próprios funcionários do Arquivo Histórico, e houve intensa manipulação dos documentos tratados durante uma mudança do prédio o presente trabalho teve como objetivo validar uma metodologia de determinação de resíduos do $\mathrm{HCH}$ e seus isômeros em soro sangüíneo, e analisar o grau de exposição dos funcionários e ex-funcionários do Arquivo Histórico de Joinville ao produto.

Foram realizados exames sorológicos em todos os funcionários e ex funcionários do local e também na população que sabidamente nunca tiveram contato com o ativo, denominada população controle. As análises foram realizadas após a validação do método multiresíduos que obtem todos os ativos em uma única extração e tem detecção por Cromatografia a gás com detector de captura (GCECD) de elétrons. Os resultados comprovaram comprovaram a eficiência do método, através de dados em conformidade com os critérios do ensaio. Os resultados obtidos no estudo da população mostraram que a quantidade de $\mathrm{HCH}$ no soro sangüíneo de funcionários, ex-funcionários e da população controle estão abaixo do limite de quantificação de $0,04 \mu \mathrm{gl}^{-1}$ para Alfa $\mathrm{HCH}$ e Gama $\mathrm{HCH}$ "Lindana" e 0,08 $\mu \mathrm{g} \mathrm{dL}^{-1}$ para Beta e Delta $\mathrm{HCH}$. 


\title{
Determination of hexachlorcyclohexane residues on blood plasma of exposed employees of the Historical Archieve of Joinville on 80 's decade. \\ Elaine Cristina Damasceno Loiola
}

\begin{abstract}
Hexachlorcyclohexane $(\mathrm{HCH})$ is an organochloride insecticide formed by a mixture of chemical isomers produced during its chemical synthesis, obtained after successive inserts of chlorine atoms on benzene molecule. These isomers may contaminate both the environment and the people who had direct or indirect contact with the $\mathrm{HCH}$ residues. On 70's and 80 's, its was used a commercial product which contained $\mathrm{HCH}$ on its formula and was commercialized as $\mathrm{Hexabel}^{\circledR}$. The product was used to control the xylophage insect population on the Historical Archieve of Joinville, at Santa Catarina, Brazil. The own employees did the insecticide application and there was an intensive manipulation of the treated material during a building change.

The objective of this work was to validate a methodology to quantify the $\mathrm{HCH}$ residues and its isomers on blood plasma and analyze the employee's exposure extent to the chemical.

It was done serological investigation on employees, former-employees and on non-exposed people, which was classified as the control population. The analyses were done after the methodology validation. The method was capable to obtain all isomers on a unique extraction and the detection and quantification were done by gas chromatography with electron-capture detector (GC-ECD). The results obtained showed that the proposed method is accurate, and that the amount of $\mathrm{HCH}$ residues on blood plasma of all individuals analyzed was lower than the quantification limits established to the method, which were $0,04 \mu \mathrm{g} \mathrm{dL}^{-1}$ for the alpha- and gamma- $\mathrm{HCH}$ (lindana) and 0,08 $\mu \mathrm{gL}^{-1}$ for the beta- and delta- $\mathrm{HCH}$.
\end{abstract}




\section{SUMÁRIO}

1. INTRODUÇÃO 14

1.1 Arquivo Histórico de Joinville/Santa Catarina 15

$\begin{array}{ll}1.2 \text { Xilófagos } & 16\end{array}$

$\begin{array}{ll}1.3 \text { Hexaclorociclohexano } & 17\end{array}$

2. OBJETIVO 18

2.1 Objetivo Geral 18

2.2 Objetivo Especifico 18

3. REVISÃO DA LITERATURA 19

3.1 Efeitos sobre a saúde humana em exposições ocupacionais ao $\mathrm{HCH} \quad 19$

3.2 Efeitos sobre a saúde humana na exposição ambiental 21

3.3 Agrotóxicos 23

3.3.1 Definição 23

3.3.2 Registro e avaliação ambiental de agrotóxicos 26

3.3.3 Utilização 27

3.3.4 Grupos Quimicos $\quad 27$

3.3.5 Toxicidade 31

3.4 Analise Cromatográfica $\quad 34$

4. MATERIAIS E MÉTODOS 38

4.1 Matriz estudada 38

4.2 Ativo estudado 38

4.3 Principio do método analítico 44

4.4 Equipamentos, materiais e solventes utilizados $\quad 44$

4.4.1 Equipamentos $\quad 44$

4.4.2 Materiais, Vidrarias e outros 44

4.4.3 Solventes e Reagentes 44

4.5 Preparação das Soluções $\quad 45$

4.5.1 Preparação das soluções de estoque "solução mãe". 45

4.5.2 Preparação das Curvas de Calibrações 45

4.6 Preparação das Amostras $\quad 55$

4.7 Extração dos ativos na amostra $\quad 57$ 
4.8 Fortificações dos ativos na amostra

4.9 Analise Instrumental $\quad 62$

4.10 Validação das adaptações ao método 63

4.11 Critérios de ensaio de conformidade 63

4.11.1 Curva de Calibração 64

4.11.2 Especificidade/Seletividade 64

4.11.3 Precisão de Medição 64

4.11.4 Exatidão/Recuperação 64

4.11.5 Limite de Detecção (LOD) e Limite de Quantificação (LOQ) 64

4.11.6 Repetibilidade 65

4.11.7 Incerteza de medição 65

5 RESULTADOS $\quad 66$

5.1 Dados de Validação $\quad 66$

5.1.1Curva de Calibração - Linearidade 66

5.1.2 Especificidade/Seletividade $\quad 73$

5.1.3 Precisão de Medição/ Exatidão/ Recuperação 73

5.2 Resultados nas amostras Grupo 1 e Grupo 2

6 DISCUSSÃO DOS RESULTADOS

7 CONCLUSÃO

8 BIBLIOGRAFIA 90 


\section{Lista de Tabela}

Tabela 1 Efeitos da exposição aos agrotóxicos.

Tabela 2 Toxicidade e persistência ambiental de alguns agrotóxicos (em escala de 1 a 5 ). .

Tabela 3 Comparação das características entre fonte radioativas de

Hidrogênio $\left({ }^{3} \mathrm{H}\right)$ e Niquel $\left({ }^{63} \mathrm{Ni}\right)$.

Tabela 4 Limite de Detecção (LOD)

Tabela 5 Limite de Quantificação (LOQ)

Tabela 6 Faixa de trabalho, equação da curva e coeficiente de correlação

Tabela 7 Eficiência da recuperação Alfa HCH

Tabela 8 Dados Globais Alfa $\mathrm{HCH}$

Tabela 9 Eficiência da recuperação Beta $\mathrm{HCH}$

Tabela 10 Dados Globais Beta HCH

Tabela 11 Eficiência da recuperação Delta HCH

Tabela 12 Dados Globais Delta $\mathrm{HCH}$

Tabela 13 Eficiência da recuperação Gama HCH 76

Tabela 14 Dados Globais Gama HCH 76

Tabela 15 Resultados - Grupo 1 "Grupo Exposto" 79

Tabela 16 Resultados - Grupo 2 "Grupo não Exposto" 80 


\section{Lista de Figura}

Figura 1 Formula estrutural do Alfa $\mathrm{HCH}$

Figura 2 Cromatograma do Alfa $\mathrm{HCH}$

Figura 3 Formula estrútural do Beta $\mathrm{HCH}$

Figura 4 Cromatograma do Beta $\mathrm{HCH}$

Figura 5 Formula estrutural do Delta $\mathrm{HCH}$

Figura 6 Cromatograma do Delta $\mathrm{HCH}$

Figura 7 Formula estrutural do Gama $\mathrm{HCH}$ - Lindana

Figura 8 Cromatograma do Gama HCH - Linadana

Figura 9 Cromatograma da Curva 1- Solução "B" Alfa $\mathrm{HCH}+$ Beta $\mathrm{HCH}$

Concentração $10 \rho g \mathrm{~L}^{-1}$ Alfa HCH e $20 \rho g \mathrm{~L}^{-1}$ Beta $\mathrm{HCH}$

Figura 10 Cromatograma da Curva 1- Solução "B" Alfa HCH + Beta HCH

Concentração $50 \rho g \mu \mathrm{L}^{-1}$ Alfa $\mathrm{HCH}$ e $100 \rho g \mathrm{~L}^{-1}$ Beta $\mathrm{HCH}$

Figura 11 Cromatograma da Curva 1- Solução "B" Alfa $\mathrm{HCH}+$ Beta $\mathrm{HCH}$

Concentração $100 \rho g \mathrm{~L}^{-1}$ Alfa $\mathrm{HCH}$ e $200 \rho g \mathrm{~L}^{-1}$ Beta $\mathrm{HCH}$

Figura 12 Cromatograma da Curva 2- Solução "A" Delta HCH + Gama HCH

Concentração $10 \rho g \mathrm{~L}^{-1} \mathrm{Gama} \mathrm{HCH}$ Lindana e $20 \rho g \mathrm{~L}^{-1}$ Delta $\mathrm{HCH}$

Figura 13 Cromatograma da Curva 2- Solução "A" Delta $\mathrm{HCH}+$ Gama HCH

Concentração 50pg $\mu \mathrm{L}^{-1}$ Gama HCH Lindana e $100 \rho g \mu \mathrm{L}^{-1}$ Delta HCH 52

Figura 14: Cromatograma da Curva 2- Solução "A" Delta HCH + Gama HCH

Concentração $100 \rho g \mathrm{~L}^{-1}$ Gama HCH Lindana e $200 \rho g \mu \mathrm{L}^{-1}$ Delta HCH 53

Figura 15: Fluxograma para analise de resíduos de $\mathrm{HCH}$ e seus isômeros em soro sangüíneo 
Figura 16 Cromatograma da Recuperação Alfa HCH + Beta HCH - 1LOQ 57

Figura 17 Cromatograma da Recuperação Alfa HCH + Beta HCH - 10LOQ 58

Figura 18 Cromatograma da Recuperação Gama HCH + Delta HCH - 1LOQ 59

Figura 19 Cromatograma da Recuperação Gama HCH + Delta HCH - 10LOQ 60

Figura 20 Curva de Calibração - Linearidade Alfa HCH 66

Figura 21 Curva de Calibração - Linearidade Beta HCH 66

Figura 22 Curva de Calibração - Linearidade Delta HCH 66

Figura 23 Curva de Calibração - Linearidade Gama HCH 67

Figura 24 Cromatograma Alfa $0,1 \rho g \mathrm{~L}^{-1}$ e Beta $0,2 \rho g \mu \mathrm{L}^{-1}$. 67

Figura 25 Cromatograma Alfa $0,2 \mathrm{pg} \mu \mathrm{L}^{-1}$ e Beta $0,4 \rho g \mu \mathrm{L}^{-1}$. 67

Figura 26 Cromatograma Alfa 1,0pg $\mu \mathrm{L}^{-1}$ e Beta $2,0 \rho g \mu \mathrm{L}^{-1}$. 68

Figura 27 Cromatograma Alfa 2,0pg $\mu \mathrm{L}^{-1}$ e Beta 4,0pg $\mu \mathrm{L}^{-1}$. 68

Figura 28 Cromatograma Alfa 10,0pg $\mu \mathrm{L}^{-1}$ e Beta $20,0 \rho g \mu \mathrm{L}^{-1}$. 68

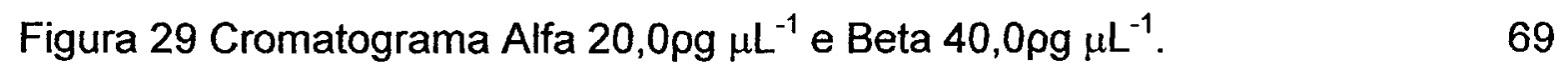

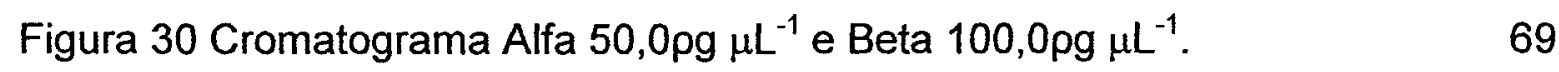

Figura 31 Cromatograma Alfa 100,0pg $\mu \mathrm{L}^{-1}$ e Beta $200,0 \rho g \mu \mathrm{L}^{-1}$. 69

Figura 32 Cromatograma Lindana $0,1 \rho g \mathrm{~L}^{-1}$ e Delta $0,2 \rho g \mu \mathrm{L}^{-1}$. 70

Figura 33 Cromatograma Lindana $0,2 \rho g \mathrm{~L}^{-1}$ e Delta $0,4 \rho g \mathrm{~L}^{-1}$. $\quad 70$

Figura 34 Cromatograma Lindana $1 p g \mu \mathrm{L}^{-1}$ e Delta $2 \rho g \mu \mathrm{L}^{-1}$. $\quad 70$

Figura 35 Cromatograma Lindana $2 \rho g \mathrm{~L}^{-1}$ e Delta $4 \rho g \mu \mathrm{L}^{-1}$. 71

Figura 36 Cromatograma Lindana $10 \rho g \mu \mathrm{L}^{-1}$ e Delta $20 \rho g \mu \mathrm{L}^{-1}$. 71

Figura 37 Cromatograma Lindana $20 \rho g \mathrm{~L}^{-1}$ e Delta $40 \rho g \mathrm{~L}^{-1}$. 71

Figura 38 Cromatograma Lindana 50pg $\mu \mathrm{L}^{-1}$ e Delta $100 \rho g \mathrm{~L}^{-1}$. 72

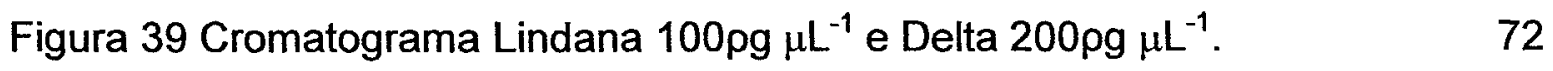




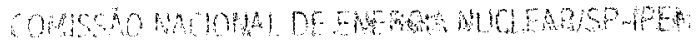




\section{INTRODUÇÃO}

O primeiro passo para desenvolver esse estudo foi traduzir na aparentemente prosaica definição semântica do que se pretende avaliar: os expostos, os intoxicados ou ambos.

Por definição: Expostos são todos aqueles que têm ou tiveram contato com determinado substância. Considerando que os agrotóxicos foram as substâncias antropogênicas mais utilizadas na história da humanidade, sendo possivel hoje encontrá - las em regiões tão inusitadas como a do Ártico e Antártica, toda a população do planeta estaria nessa condição. Intoxicados, são aqueles que tiveram contato com determinada substância e deste contato desenvolveram algum tipo de manifestação clínica. (Peres, F. 2003).

A partir destas definições pode-se iniciar as análises de soro sangüineos dos trabalhadores e ex - trabalhadores do Arquivo Histórico de Joinville expostos ao Hexaclorociclohexano, utilizado em documentos e livros para controle de insetos xilófagos.

No homem, esses compostos podem ser identificados no sangue, no plasma, no soro, no tecido adiposo e no leite. No Brasil, o uso geral desse pesticida foi proibido em 1985, ficando o mesmo restrito apenas a campanhas de saúde pública (Portaria do Ministério da Agricultura n 329 de 2.9.1985).

A toxicidade seletiva dos pesticidas contra o organismo a que se pretende combater é a situação ideal desejável para sua utilização; entretanto, essas substâncias podem provocar alguma toxicidade em seres humanos. Portanto, não se deve considerar um pesticida completamente seguro. Essas substâncias necessitam ser utilizadas de forma adequada, de maneira que não venha causar maiores riscos para a saúde humana. (Nunes, F. P. 2002). 


\subsection{ARQUIVO HISTÓRICO DE JOINVILLE/ SANTA CATARINA}

O Arquivo Histórico de Joinville, como é conhecido por seus freqüentadores, foi criado pela Lei Municipal n. 1.182 de 20 de março de 1972 e "é uma unidade subordinada à Fundação Cultural de Joinville, que tem por finalidade recolher, guardar, conservar, restaurar e preservar a documentação produzida por instituições governamentais de âmbito municipal, bem como, os documentos privados de interesse público, sob sua guarda, garantindo acesso público às informações neles contidas, com o objetivo de apoiar as instâncias dos poderes públicos municipais nas suas decisões político-administrativas, o cidadão na defesa de seus direitos e de incentivar a pesquisa relacionada com o desenvolvimento regional".

De 1972 até 1986 o Arquivo funcionou em uma das salas da Biblioteca Pública Municipal "Rolf Colin", localizada na Praça Lauro Müller. A inauguração do atual prédio, fruto de um convênio firmado entre a Prefeitura Municipal de Joinville e o Governo da Alemanha, realizou-se em 18/07/1986. Nestes 30 anos passou por diferentes momentos, estando sempre presente no auxílio aos pesquisadores que se dedicam a construir histórias sobre Joinville e região. Hoje, através da experiência acumulada durante o transcorrer dos anos, mantém a responsabilidade de recuperar e divulgar informações, tornando-se uma instituição dinâmica no desenvolvimento de seu potencial científico, educativo e cultural junto à sociedade.

Nas décadas de 1970 e 1980 o "Hexabel®" - hexaclorociclohexano, um inseticida do grupo dos organoclorados, foi utilizado no Acervo Histórico de Joinville no combate a insetos xilófagos. Neste período o acervo localizava-se no prédio antigo e a aplicação foi efetuada por um funcionário do próprio Arquivo Histórico, diretamente nos livros e nos lotes dos documentos avulsos. Em 1986 ocorreu a mudança para o prédio atual e todo o material foi manipulado exaustivamente para realizar uma nova listagem da documentação, sendo que a manipulação provocou uma possível migração do inseticida para o ambiente, o que foi comprovado por análises realizadas em livros. Com essa evidência, surgiu a suspeita de que uma possível intoxicação nos funcionários poderia ter ocorrido. Este episódio foi o 
primeiro alerta para a periculosidade do produto, mas nenhuma medida de segurança foi realizada e os funcionários continuaram expondo-se ao longo de muitos anos, sem qualquer controle da exposição ocupacional (Barotto, A. M 2003).

Em 2003, por iniciativa do Centro de Informações Toxicológicas de Santa Catarina - SIT/SC e o Departamento de Saúde Pública - SPB/UFSC foram iniciados estudos para verificar o grau de exposição dos funcionários e ex - funcionários ao produto, sendo o soro sanguíneo encaminhado ao Laboratório de Análise de Resíduos de Pesticidas do Instituto Adolfo Lutz para deteç̧ão do pesticida.

\subsection{Xilófagos}

A madeira está sujeita à degradação por organismos que dela se alimentam. No lenho estão presentes muitas substâncias nutritivas, como açúcares, carboidratos, gomas, resinas e amidos, que constituem a base alimentar de uma infinidade de organismos, dentre os quais, fungos, bactérias, insetos, moluscos e crustáceos. Estes organismos que degradam a madeira são conhecidos por xilófagos (do grego xylon, madeira e fagus, comer).

Os fungos atacam em geral a madeira que apresenta um teor de umidade favorável ao seu desenvolvimento. O tipo de ataque é classificado de acordo com o fungo que se instala na madeira.

Dos insetos que atacam a madeira serrada, os besouros e os cupins estão dentre os que causam piores danos. Traças, vespas, mariposas e outros em menor escala de importância também depositam seus ovos em peças de madeira ou utilizam-na como fonte de alimento.

Em relação aos besouros (ordem Coleoptera), existe uma grande variedade que ataca a madeira e causa prejuízos relevantes (cerambycidae, scolytidae, platypodidae, bostrychideae, lyctidae e anobidae, entre outras). Os ovos podem ser depositados no lenho das árvores ou na madeira já cortada. Apesar de alguns serem muito pequenos (os escolitídeos e os platipodídeos não ultrapassam $1 \mathrm{~mm}$ de comprimento) promovem ataques devastadores na madeira: estão associados naturalmente a fungos, dos quais, em alguns casos, se alimentam. Os cupins que atacam a madeira alimentam-se fundamentalmente de celulose. São classificados 
dentro da ordem Isoptera. Estão, em geral, associados a microrganismos simbióticos que promovem a degradação enzimática da celulose presente no xilema. A estrutura social destes insetos é altamente organizada e complexa, com a colônia dividindo-se em várias castas hierárquicas.

\subsection{Hexaclorociclohexano}

1,2,3,4,5,6-hexaclorociclohexano $(\mathrm{HCH})$ de fórmula química $\mathrm{C}_{6} \mathrm{H}_{6} \mathrm{Cl}_{6}$ é uma substância química produzida industrialmente, conhecida com o nome de $\mathrm{BHC}$ (hexacloreto de benzeno). De acordo com as regras da IUPAC, a designação "hexacloreto de benzeno" é incorreta. Apesar disso, a denominação BHC é ainda largamente utilizada, principalmente no âmbito da agricultura, adotado, inclusive, pela Organização de Agricultura e Alimentação (FAO), enquanto a organização Mundial da Saúde (OMS), utiliza corretamente a denominação $\mathrm{HCH}$. O HCH existe em oito formas quimicas chamadas isômeros. Uma das formas, o isômero gama ( $\delta)$, também conhecido como lindano e lindana, é uma substância cristalina branca, que pode evaporar-se no ar como um vapor incolor, sem odor ou com um leve odor próprio (acredita-se que o odor se deva a impurezas, principalmente o heptaclorociclohexano). No seu grau técnico, o $\mathrm{HCH}$ constituía-se, de uma mistura de isômeros e outras impurezas, com destaque para os isômeros $\alpha$ (65-70\%), $\beta$ (7$10 \%), \delta(14-15 \%)$ e outros (5\%), considerados como subprodutos ou "impurezas" do lindano ou isômero gama. Atualmente, em função das exigências de qualidade, o lindano deve ter pelo menos $99 \%$ de HCH (World Health Organization, 1991).

$\mathrm{O} \mathrm{HCH}$ foi sintetizado pela primeira vez por Michael Faraday em 1825 e quatro de seus estéreoisômeros foram demonstrados por Van der Linden em 1912.

Em 1825, o HCH foi utilizado na primeira Guerra Mundial como arma química na forma de gás tóxico para fins bélicos (entre muitos outros gases de guerra). As propriedades inseticidas foram descobertas em 1942, e a partir de 1949, о HCH passou a ser largamente produzido e utilizado com finalidades econômicas, na agricultura, como inseticida de largo espectro em culturas de frutas e vegetais; em silos, tendo sido também utilizado para fins não-agrícolas, quer como droga para tratamentos tópicos contra ectoparasitos do ser humano e de animais (na forma 
líquida, em loções, cremes, xampu, pós, etc.), quer em campanhas de Saúde Pública, no combate ao vetor da malária e, entre nós, também dos triatomídeos vetores da doença de Chagas (Van Ert \& Sullivan Jr., 1992).

O lindano foi produzido e comercializado em várias formas de apresentação e formulações. A mais importante tem sido na forma de pós molháveis (até $90 \%$ de $\mathrm{HCH}$ ); concentrações emulsificáveis (até $20 \%$ de $\mathrm{HCH}$ ); soluções em água ou em solventes orgânicos (até $50 \%$ de $\mathrm{HCH}$ ); grânulos $(3-4 \%$ de $\mathrm{HCH}$ ); iscas; aerossóis e formulações especiais para uso tópico, em medicina humana e veterinária. Outrossim, muito se utilizou na forma de preparações para fumigação em ambientes fechados, em concentrações de $\mathrm{HCH}$ praticamente puras (World Health Organization, 1991).

$\mathrm{Na}$ maioria dos países, o $\mathrm{HCH}$ deixou de ser produzido a partir do final da década de 70, tendo deixado de ser utilizado nesses países a partir de 1983 a 1985 (Van Ert \& Sullivan Jr., 1992; Agency For Toxic Substances And Disease Registry, 1989; 1990).

No Brasil, os praguicidas organoclorados de alta persistência foram proibidos para uso agrícola, em 1985, permanecendo seu uso para fins de combate a vetores transmissores de doenças infecciosas (Brasil, 1985).

O Hexaclorociclohexano era sintetizado por meio de adições sucessivas de cloro ao benzeno, gerando os isômeros $\alpha, \beta, \sigma$, e $\gamma \mathrm{HCH}$ em diferentes percentuais estequiométricos. $\mathrm{O}$ isômero $\gamma-\mathrm{HCH}$, de maior ação inseticida, era sintetizado com um percentual de 14 a $15 \%$ da mistura técnica.

Os isômeros do $\mathrm{HCH}$ podem contaminar não só o meio ambiente como também a população que tenha contato direto ou indireto com os resíduos. Os $\mathrm{HCHs}$ são apolares, têm baixa solubilidade em água e alta estabilidade no meio ambiente, o que dificulta a degradação dos mesmos. De acordo com a Secretaria Nacional de Vigilância Sanitária, o HCH é classificado como Classe I, extremamente tóxico. Segundo o Centro Internacional de Investigação sobre Câncer, o $\mathrm{HCH}$ é "possivelmente carcinogênico a humanos" (International Agency for Research um Cancer, 1987). A contaminação humana pode ocorrer de forma aguda ou crônica, por meio das vias dérmica, respiratória e alimentar. Os isômeros do $\mathrm{HCH}$ são altamente lipofílicos e persistentes, sendo armazenados nos tecidos gordurosos. 
Assim, mesmo sendo absorvidos em pequenas quantidades, se a exposição é prolongada (crônica), efeitos adversos à saúde podem ser observados, como por exemplo, danos ao sistema nervoso central (World Health Organization, 1991, 1992). 


\section{OBJETIVO}

\subsection{Objetivo Geral}

O objetivo deste trabalho foi de analisar o soro sangüineo dos funcionários ex - funcionários do Arquivo Histórico de Joinville Santa Catarina e um grupo controle de pessoas sabidamente não expostas ao produto estudado. Validar as adaptações da metodologia analítica USEPA N.C. 27711 utilizadas na Seção de Resíduos de Pesticidas do Instituto Adolfo Lutz.

\subsection{Objetivos Especificos}

1) Identificar a melhor técnica de analise do hexaclorociclohexano e seus isômeros.

2) Utilizar um método multiresíduos onde uma única extração é feita para todos os ativos estudados sem que haja perda de nenhum deles.

3) Verificar o comportamento de cada isômeros no momento de armazenamento, extração e injeção no equipamento, assim como as melhores condições cromatográficas.

4) Otimizar a rampa cromatográfica da melhor maneira para que todos os ativos eluam totalmente distintos e na mesma corrida, da coluna cromatográfica.

5) Realizar a validação da metodologia analítica.

6) Analisar os soros sangüíneo dos funcionários e ex-funcionários do Arquivo Histórico de Joinville e também da população controle, não exposta ao $\mathrm{HCH}$. 


\section{REVISÃO DA LITERATURA}

\subsection{Efeitos sobre a saúde humana em exposições ocupacionais ao $\mathrm{HCH}$}

Nas situações de exposição direta a vapores de $\mathrm{HCH}$, como em ambientes de trabalho fechados, ou após aplicações de $\mathrm{HCH}$ em paredes, plantas, animais, livros e outros tanto o gama $\mathrm{HCH}$ também conhecido como 'lindana' ou 'lindano' bem como os isômeros do $\mathrm{HCH}$, alfa, beta e delta, podem causar irritação das vias respiratórias altas (nariz e garganta); irritação pulmonar; alterações cardiacas; alterações sangüineas (anemia); efeitos sobre a pele (irritação e prurido) e convulsões (Agency For Toxic Substances And Disease Registry, 1989; 1990).

A observação desses efeitos tem sido feita em trabalhadores que inalaram grandes quantidades, na fabricação ou em aplicações, de $\mathrm{HCH}$ na agricultura e em domicílios, como também em circunstâncias acidentais. Nessas circunstâncias, relativamente raras, pode ocorrer a morte. Alguns estudos de toxicidade aguda e de curta duração na espécie humana indicam que uma dose aproximada de 1,0 $\mathrm{mg} / \mathrm{kg}$ de peso corporal não produz intoxicação. No entanto, com uma dose de 15$17 \mathrm{mg} / \mathrm{kg}$ de peso corporal, observam-se sintomas de intoxicação grave (Agency For Toxic Substances And Disease Registry, 1989; 1990; World Health Organization, 1991a; 1991b; 1991c;1991d).

Sobre os efeitos da exposição ocupacional ao lindano, o documento do Programa Internacional de Segurança das Substâncias Químicas (IPCS) conclui em suas 208 páginas da revisão feita em 1991, nos seguintes termos:

"apesar do uso generalizado do $\mathrm{HCH}$, durante mais de 40 anos, há notificação de apenas poucos casos de intoxicação de natureza ocupacional. Nos trabalhadores expostos durante longos períodos, na fabricação ou na aplicação de lindano, o único sintoma observado foi uma maior atividade das enzimas hepáticas metabolizadoras de fármacos. Não há provas de relação, sugeridas em outras publicações, entre a exposição ao lindano e o aparecimento de anomalias hematológicas" (World Health Organization, 1991d).

Por sua vez, sobre os efeitos da exposição ocupacional ao alfa- e beta- 
hexaclorociclohexanos o documento do IPCS, produzido em 1991, conclui suas 170 páginas com um resumo de três linhas, onde se utilizam as seguintes palavras:

"Se observam as precauções recomendadas para reduzir ao mínimo a exposição das pessoas que trabalham na fabricação do Lindano, o alfa- e beta-HCH não significarão risco para a saúde dos trabalhadores" (World Health Organization, 1991c).

Estudos realizados no Brasil, com grupos ocupacionalmente expostos ao $\mathrm{HCH}$, mostraram que nas exposições ocupacionais de médio e longo prazo, em concentrações insuficientes para causar quadros agudos de irritação respiratória, dérmica ou gástrica, podem, de fato, ocorrer alterações da função hepática, avaliadas pela elevação das transaminases (TGP e TGO), pela fosfatase alcalina e pela albumina, com elevações mais acentuadas nos indivíduos com mais elevada exposição, demonstrando assim uma relação dose-resposta importante para esse tipo de dano (Carvalho, et al, 1989).

Nos trabalhadores com exposição mais elevada, (Carvalho, et al, 1989) constataram, também, alterações hematológicas, destacando-se uma leucocitose com neutrofilia e linfocitopenia.

O estudo realizado com trabalhadores da Superintendência de Controle das Endemias (SUCEN), em São Paulo, "cronicamente expostos" ao HCH e DDT, levou o médico Francisco Gonçalves a concluir, em sua Dissertação de Mestrado, que:

"há desinformação dos riscos de exposição ocupacional aos inseticidas e falta de fornecimento e uso de equipamento de proteção no trabalho. Em relação à exposição aos inseticidas, não foi encontrado um quadro clínico específico de intoxicação, o mesmo observado no exame neurológico e eletroencefalográfico. Também não foram observadas diferenças significativas nos exames hematológicos e bioquímicos de sangue. Os teores de DDT e BHC foram maiores no grupo exposto em relação ao controle. O exame citogenético revelou aumento da freqüência de certos tipos de aberrações cromossômicas estruturais, no grupo exposto em relação ao controle. Concluímos ser necessária a implantação de um Programa de Saúde do Trabalhador, com longo tempo de seguimento clínico e laboratorial, para os trabalhadores expostos ocupacionalmente a inseticidas" (Gonçalves, 1991).

Nas exposições ocupacionais (inalatórias), tanto a Agência de Administração 
da Saúde e Segurança Ocupacional (OSHA), como o Instituto Nacional de Saúde e Segurança Ocupacional (NIOSH), e a Conferência Americana dos Higienistas Industriais Governamentais (ACGIH), dos Estados Unidos, fixaram em 0,5 $\mathrm{mg} / \mathrm{m}^{3}$ de ar, respectivamente o Limite de Exposição Permitido (PEL), o Limite de Exposição Recomendado por Razões de Saúde (REL) e o Limite de Tolerância (TLV) do hexaclorociclohexano, sempre para oito horas de exposição diária, 40 horas semanais.

\subsection{Efeitos sobre a saúde humana na exposição ambiental}

A literatura científica traz algumas centenas de trabalhos científicos experimentais, realizados in vivo e in vitro, alguns escassos informes de casos clínicos de intoxicações agudas, e ainda mais escassos estudos epidemiológicos capazes de construir um relativo consenso sobre os efeitos, de médio e longo prazos, da exposição "ambiental" ao hexaclorociclohexano. Quando o faz, aborda exposições acumuladas no correr do tempo, principalmente de "fontes de base" (background contamination), geralmente representadas pela ingestão de resíduos clorados em alimentos de origem animal.

No caso particular de interesse deste documento, isto é, de exposições ambientais em fontes fixas, por poluição do solo, água e, eventualmente, alimentos de origem vegetal ou animal oriundos de área poluída - especificamente as condições descritas no "caso Cidade dos Meninos" (Oliveira, 1994; Oliveira, Brilhante, Moreira \& Miranda, 1995; Bastos, 1999) - não se encontra similar na literatura cientifica internacional e nacional.

No Brasil, as condições mais parecidas, embora com outra molécula clorada - o hexaclorobenzeno (HCB) - ocorridas na Baixada Santista, ainda não permitiram formar um consenso mais sólido sobre os eventuais efeitos adversos sobre a saúde humana em expostos ambientalmente, isto é, não ocupacionalmente, constituindose os trabalhos de Santos Filho e colaboradores (1993) e de Silva, Barretto, Lemes \& Kussumi (1997), nos únicos informes publicados, mas inteiramente voltados à avaliação biológica da exposição, e não à pesquisa de efeitos adversos sobre a 
saúde. O trabalho de Augusto e Freitas (1995) constitui exceção, mas aborda tãosomente efeitos da exposição ocupacional em trabalhadores da indústria química responsável pela poluição ambiental, localizada em Cubatão - SP, poluição que se estendeu a outras áreas da Baixada Santista, graças à deposição indevida de resíduos clorados, em múltiplos sites, atualmente próximos a moradias de pessoas.

Com esta breve introdução e visão panorâmica do estado atual do conhecimento em matéria de efeitos adversos sobre a saúde humana, decorrentes da exposição de médio e longo prazos ao $\mathrm{HCH}$ (e provavelmente também ao DDT e outros resíduos clorados), tentaremos resumir, a seguir, os principais ângulos em que esta matéria tem sido abordada na literatura científica, e que, portanto, mereceriam ser mais aprofundados e seguidos no espírito do "princípio da precaução" (Augusto \& Freitas, 1998) e com estratégias da "vigilância da saúde".

$\mathrm{Na}$ Tabela 1, apresenta-se um sumário dos principais efeitos agudos e crônicos causados pela exposição aos principais agrotóxicos disponíveis, de acordo com a praga que controlam e o grupo químico ao qual pertencem. 
Tabela 1: Efeitos da exposição aos agrotóxicos. Classificação quanto à praga que controla, Classificação quanto ao grupo químico, Sintomas de intoxicação aguda e Sintomas de intoxicação crônica

\begin{tabular}{|c|c|c|c|}
\hline $\begin{array}{l}\text { Classificação } \\
\text { quanto à } \\
\text { praga que } \\
\text { controla }\end{array}$ & $\begin{array}{l}\text { Classificação } \\
\text { quanto ao grupo } \\
\text { qüímico }\end{array}$ & $\begin{array}{l}\text { Sintomas de } \\
\text { intoxicação aguda }\end{array}$ & $\begin{array}{l}\text { Sintomas de } \\
\text { intoxicação } \\
\text { crônica }\end{array}$ \\
\hline Inseticidas & $\begin{array}{l}\text { Organofosforados } \\
\text { e Carbamatos }\end{array}$ & $\begin{array}{l}\text { - Fraqueza; } \\
\text { - Cólicas; } \\
\text { abdominais; } \\
\text { - Vômitos; } \\
\text { - Espasmos } \\
\text { musculares; } \\
\text { - Convulsões. }\end{array}$ & $\begin{array}{l}\text { - Efeitos } \\
\text { neurotóxicos } \\
\text { retardados; } \\
\text { - Alterações } \\
\text { cromossomiais; } \\
\text { - Dermatites de } \\
\text { contato. }\end{array}$ \\
\hline Inseticidas & Organoclorados & $\begin{array}{l}\text { - Náuseas; } \\
\text { - Vômitos; } \\
\text { - Contrações } \\
\text { musculares } \\
\text { involuntários. }\end{array}$ & $\begin{array}{l}\text { - Lesões hepáticas; } \\
\text { - Arritmias } \\
\text { cardíacas; } \\
\text { - Lesões renais; } \\
\text { - Neuropatias } \\
\text { periféricas. }\end{array}$ \\
\hline Inseticidas & $\begin{array}{l}\text { Piretróides } \\
\text { sintéticos }\end{array}$ & $\begin{array}{l}\text { - Irritação das } \\
\text { conjuntivas; } \\
\text { - Espirros; } \\
\text { - Excitação; } \\
\text { - Convulsões. }\end{array}$ & $\begin{array}{l}\text { - Alergias; } \\
\text { - Asma brônquica; } \\
\text { - Irritações nas } \\
\text { mucosas; } \\
\text { - Hipersensilidade. }\end{array}$ \\
\hline Fungicidas & Ditiocarbamatos & $\begin{array}{l}\text { - Tonteiras; } \\
\text { - Vômitos; } \\
\text { - Tremores } \\
\text { musculares; } \\
\text { - Dor de cabeça. }\end{array}$ & $\begin{array}{l}\text { - Alergias } \\
\text { respiratórias; } \\
\text { - Dermatites; } \\
\text { - Doenças de } \\
\text { Parkinson; } \\
\text { - Cânceres. }\end{array}$ \\
\hline Herbicidas & $\begin{array}{l}\text { Dinitrofenóis e } \\
\text { Pentaclorofenol }\end{array}$ & $\begin{array}{l}\text { - Dificuldade } \\
\text { respiratória; } \\
\text { - Hipertermia; } \\
\text { - Convulsões. }\end{array}$ & $\begin{array}{l}\text { - Cânceres (PCP- } \\
\text { formação de } \\
\text { dioxinas); } \\
\text { - Cloroacnes. }\end{array}$ \\
\hline Herbicidas & Dipiridilos & $\begin{array}{l}\text { - Sangramento } \\
\text { nasal; } \\
\text { - Fraqueza; } \\
\text { - Desmaios; } \\
\text { - Conjuntivite. }\end{array}$ & $\begin{array}{l}\text { - Lesões hepáticas; } \\
\text { - Dermatites de } \\
\text { contato; } \\
\text { - Fibrose pulmonar. }\end{array}$ \\
\hline
\end{tabular}

Fonte: WHO, 1990. 


\subsection{Agrotóxicos}

\subsubsection{Definição}

Agrotóxico, defensivos agrícolas, pesticidas, praguicidas, remédios de planta, veneno, essas são algumas das inúmeras denominações relacionadas a um grupo de substâncias químicas utilizadas no controle de pragas (animais e vegetais) e doenças de plantas (Fundacentro, 1998). São utilizados nas florestas nativas e plantações, nos ambientes hídricos, urbanos e industriais e, em larga escala, na agricultura e nas pastagens para a pecuária, sendo também empregados nas campanhas sanitárias para o combate a vetores de doenças. Tão extensa quanto a lista de efeitos nocivos dos agrotóxicos à saúde humana é a discussão sobre a nomenclatura correta dessa gama de produtos, a qual, de acordo com os interesses de grupos envolvidos, pode dar-lhes conotações muitas vezes opostas ao sentido real (Peres, F. et al. 2003).

Segundo a Norma Regulamentar Rural $n^{\circ} 5$ (NRR 5) acompanhada da Lei Federal $\mathrm{n} 7.802$, de 11 de julho de 1989, atualmente regulamentada pelo Decreto 4.074, de 4 de janeiro de 2002.: Entende-se por agrotóxicos as substâncias, ou misturas de substâncias, de natureza química quando destinadas a prevenir, destruir ou repelir, direta ou indiretamente, qualquer forma de agentes patogênicos ou de vida animal ou vegetal, que seja nociva às plantas e animais úteis, seus produtos e subprodutos e ao homem.

Segundo o grupo de pós - graduação em Agroecologia da Universidade Federal Rural do Rio de Janeiro, em reportagem publicada no jornal informativo do Conselho Regional de Química, da Terceira Região: O termo defensivo agrícola carrega uma conotação errônea de que as plantas são completamente vulneráveis a pragas e doenças, e esconde os efeitos negativos à saúde humana e ao meio ambiente. O termo agrotóxico é mais ético, honesto e esclarecedor, tanto para os agricultores como para os consumidores. (Informativo CRQ III, 1997).

$\mathrm{Na}$ literatura internacional, o grupo de substâncias/ produtos químicos aqui 
definidos como agrotóxico recebe a denominação de pesticidas (pesticide). $\mathrm{O}$ termo "agroquímico" - o mais próximo de agrotóxico encontrado em literatura de língua inglesa (agrochemicals) e, em menor escala, também na língua portuguesa engloba um número maior de produtos, como fertilizantes e adubos inorgânicos. Portanto, não representa o real sentido do termo agrotóxico, que indica não apenas a sua finalidade de uso, mas também o caráter prejudicial destas substâncias, visualizado no radical "tóxico" (Peres, F. et al. 2003).

No campo, esses insumos são amplamente conhecidos por "veneno"ou "remédio" pelos trabalhadores rurais. Remédio tem origem no discurso de vendedores e técnicos ligados à indústrias, que tratavam os agrotóxicos por "remédios de plantas", quando da implantação deles no mercado brasileiro, por volta da década de 60 . Já o termo "Veneno" deriva da experiência concreta do trabalhador rural, que, desde o início da utilização dos agrotóxicos no meio rural vem observando, além de seus efeitos previstos - matar pragas - , também seus efeitos nocivos a saúde humana e animal por exemplo, morte de peixes, roedores, animais domésticos, intoxicação dos trabalhadores e pessoas expostas (Peres, F. et al. 2003).

Segundo a Food and Agriculture Organization (FAO), Programa da Organização das Nações Unidas (ONU) responsável pelas áreas de agricultura e alimentação, os agrotóxicos são definidos como: qualquer substâncias, ou misturas de substâncias, usadas para prevenir, destruir ou controlar qualquer praga incluindo vetores de doenças humanas e animais, espécies indesejadas de plantas ou animais, causadoras de danos durante (ou interferindo) a produção, processamento, estocagem, transporte ou distribuição de alimentos, produtos agrícolas, madeiras e derivados, ou que deva ser administrada para o controle de insetos, aracnídeos e outras pestes que acometem os corpos de animais de criação. (FAO, 2003).

De acordo com a Lei Federal $n^{\circ} 7.802$, em seu Artigo 2, Inciso 1, que trata sobre esse grupo de substâncias/ agentes no país: Agrotóxicos e afins são os produtos e os componentes de processos físicos, químicos ou biológicos destinados ao uso no setor de produção, armazenamento e beneficiamento de produtos agrícolas, nas pastagens, na proteção de florestas nativas ou implantadas e de 
outros ecossistemas e também em ambientes urbanos, hídricos e industriais, cuja finalidade seja alterar a composição da flora e da fauna, a fim de preservá-la da ação danosa de seres vivos considerados nocivos, bem como substâncias e produtos empregados como desfolhantes, dessecantes, estimuladores e inibidores do crescimento. 


\subsubsection{Registro e avaliação ambiental de agrotóxico}

A aprovação do registro de um agrotóxico significa o reconhecimento e a garantia de que o produto, quando utilizado da maneira recomendada, esteja dentro dos limites de segurança aceitos para a saúde e o ambiente.

Para a obtenção do registro no Brasil, até 1989, os agrotóxicos eram submetidos apenas às avaliações toxicológicas e de eficácia agronômica. Após a regulamentação da Lei $n^{\circ} 7.802$, de 11 de julho de 1989 , pelo Decreto $n^{\circ} 98.816$, de 11 de janeiro de 1990, passaram a ser exigidas também a avaliação e a classificação do potencial de periculosidade ambiental.

A legislação atual, compete ao Ministério da Agricultura e Abastecimento realizar a avaliação da eficácia agronômica, ao Ministério da Saúde executar a avaliação e classificação toxicológica e ao Ministério do Meio Ambiente, por meio do Instituto Brasileiro do Meio Ambiente e dos Recursos Naturais Renováveis (Ibama), avaliar e classificar o potencial de periculosidade ambiental. Os órgãos estaduais e do Distrito Federal, dentro de sua área de competência, devem realizar o controle e a fiscalização da comercialização e uso desses produtos na sua jurisdição.

A legislação brasileira prevê a proibição de registro de agrotóxicos e, conforme o estabelecido no Artigo $n^{\circ} 3$, Inciso $6^{\circ}$, essa proibição pode ocorrer nas seguintes situações:

a) para os quais o Brasil não disponha de métodos para a desativação de seus componentes;

b) para os quais não haja antídoto ou tratamento eficaz no país;

c) que revelem características teratogênicas, carcinogênicas ou mutagênicas;

d) que provoquem distúrbios hormonais e danos ao aparelho reprodutor;

e) que se revelem mais perigosos para o homem do que os testes de laboratório, com animais, tenham podido demostrar; e

f) cujas características causem danos ao meio ambiente.

Outra atividade importante no controle dos agrotóxicos desenvolvidas pelo Ibama é a verificação dos teores de impurezas tóxicas (dioxinas, nitrossaminas, 
DDT e seus isômeros e outros) e da composição quali-quantitativa dos produtos. A verificação dos teores de impurezas tóxicas é realizada por meio da avaliação das análises do teor de impurezas, das informações sobre produção/ importação prestadas pelas empresas registrantes e de ações de fiscalização (Peres, F. et al. 2003).

\subsubsection{Utilização}

Desde a década de 50 , quando se iniciou a chamada "revolução verde", foram observadas profundas mudanças no processo tradicional do trabalho agricola, bem como em seus impactos sobre o ambiente e a saúde humana. Novas tecnologias, muitas delas baseadas no uso extensivo de agentes químicos, foram disponibilizadas para o controle de doenças, aumento da produtividade e proteção contra insetos e outras pragas (Peres, F. et al. 2003).

$\mathrm{Na}$ década de 70 a comercialização dos pesticidas organoclorados foi proibida na maioria dos países devido a sua longa persistência no ambiente e no Brasil, seu uso foi limitado pela Portaria 329 de 02/09/85 Ministério da Agricultura, permitindo sua utilização somente no controle a formigas (Aldrin) e em campanhas de saúde pública (DDT e $\mathrm{HCH}$ ). As formas de exposição da população aos agrotóxicos podem ser acidental, ocupacional, pelo contato com utensílios domésticos utilizados para pulverização e com embalagens de descarte de produtos químicos e, pela água, alimentos e o ar contaminados.

\subsubsection{Grupos Químicos}

Os agrotóxicos pertencem a diferentes grupos químicos sendo que entre eles os mais estudados foram os:

- Organofosforados;

- Carbamatos;

- Piretróides; e

- Organoclorados (OPAS, 2000) 


\section{ORGANOFOSFORADOS}

São compostos orgânicos derivados do ácido fosfórico, do ácido tiosfórico ou do ácido ditiofosfórico são eles: paration, malation, diazinon, etion, forato, monocrotofós, metamidofós e outros. De acordo com a sua estrutura química, esses agrotóxicos podem ser classificados em: fosforados, tiofosforados, flúor e cianofosforados (Nunes 2002).

São inibidores das colinesterases e são absorvidos pela pele, por ingestão ou por inalação. Sua ação se dá pela inibição de enzimas colinesterases, especialmente a acetilcolinesterase, levando a um acúmulo de acetilcolina nas sinapses nervosas, desencadeando uma série de efeitos parassimpaticomiméticos.

Estes produtos não são acumulativos no organismo humano, sendo facilmente degradados e excretados. A eliminação ocorre principalmente pela urina.

\section{CARBAMATOS}

São compostos derivados do ácido carbâmico sendo os mais comuns: aldicarb, carbaril e carbofuran.

Os carbamatos, especialmente quando em formulações sólidas, são pouco absorvidos pelo organismo humano. A absorção dérmica do carbaril não é considerada importante no aparecimento dos efeitos tóxicos em indivíduos empregados na produção industrial, entretanto a presença de produto biotransformado na urina indica a absorção do composto em trabalhadores expostos.

Diferentemente dos organofosforados, os carbamatos são inibidores reversiveis das colinesterases, porém as intoxicações podem ser igualmente graves.

\section{PIRETRÓIDES}

Inseticidas Piretróides são compostos sintéticos que apresentam estruturas semelhantes à piretrina, substância existente nas flores do Chrysanthemum (Pyrethrum) cinerariaefolium. Alguns desses compostos são: aletrina, resmetrina, 
decametrina, cipermetrina e fenpropanato. A alta atividade inseticida dos piretróides possibilita seu emprego em pequenas dosagens, que associada à sua seletividade, tem permitido o aparecimento de novos produtos de origem sintética, inclusive mais estáveis à luz e menos voláteis que os de origem natural, propiciando sua grande difusão como domissanitários ou para uso na agropecuária. São facilmente absorvidos pelo trato digestivo, pela via respiratória e pela via cutânea. Sendo pouco tóxicos do ponto de vista agudo, são entretanto, irritantes para os olhos e mucosas, e principalmente hipersensibilizantes, causando tanto alergias de pele como asma brônquica. Seu uso abusivo nos ambientes domésticos vem causando incremento dos casos de alergia, tanto em crianças como em adultos. Em doses muito altas podem determinar neuropatias, por agir na bainha de mielina, desorganizando-a, além de promover ruptura de axônios.

Descobertos a partir de estudos de síntese que procuravam modificar a estrutura química das piretrinas naturais. Seu interesse de estudo se baseou na maior capacidade letal para os insetos, propriedades físicas e químicas muitos superiores, maior estabilidade à luz e calor e menor volatilidade.

Foram introduzidos no mercado em 1976, e ainda que sejam mais caros por unidade de peso em relação aos outros pesticidas, os piretróides têm sido bastante empregados na área da Saúde e na Agricultura. Isto ocorre devido à alta eficiência, sendo necessárias menores quantidades de ingrediente ativo nas formulações, resultando em menor contaminação nas aplicações. Com isso, vêm tomando rapidamente o lugar dos organofosforados. Outra vantagem é que eles admitem a sinergia, ou seja, a potencialização pela adição de um sinergista, dando lugar a um aumento da eficácia. Geralmente seguros para mamíferos, algumas substâncias tem alto "knockdown", com alta mortalidade.

Os piretróides sintéticos têm boa estabilidade a irradiação luz e temperatura ambiente. Degradam-se por hidrólise e oxidação, sendo caracterizados também pela rápida degradação por microrganismos do ambiente, não se registrando acumulação de resíduos ou esta alcança níveis não detectáveis. São os compostos de mais rápida ação na interferência da transmissão de impulsos nervosos. Podem possuir efeito repelente, espantando os insetos ao invés de eliminá-los. Atuam no sistema nervoso central e periférico, interagindo com os canais de sódio, tanto nos 
continuaram sendo usadas nos países em desenvolvimento embora tivesse sido altamente eficaz no controle de doenças transmitidas por vetores. 


\subsubsection{Toxicidade}

O Hexaclorociclohexano foi produzido no mundo para uso como inseticida para controlar gafanhotos, pestes do algodão e do arroz, larvas de elaterídeo e outras pestes do solo. O lindano tem sido usado para a proteção de sementes, para o tratamento de aves e animais de granja e para o controle de insetos domésticos. Também é usado na escabiose e como pediculicida, geralmente em loções, cremes exampus.

$\mathrm{O} \mathrm{HCH}$ - alfa, beta e gama são isômeros mais importantes em termo de impacto ambiental. A estabilidade e lipofília relativamente alta do $\mathrm{HCH}$ e o seu padrão de uso global resultaram em contaminação ambiental significativa por esse hidrocarboneto clorado. Uma vez introduzido no meio ambiente, o $\mathrm{HCH}$ pode persistir por muitos anos. $\mathrm{O}$ isômero beta é mais persistente do que os outros (ATSDR 1990). O gama-HCH é a forma mais conhecida mundialmente, e foi isolada das demais em 1912, com 99\% de pureza sendo a mais usada, por apresentar as seguintes vantagens:

- Não tem odor desagradável possibilitando o uso como domos sanitário

- Não altera o gosto e o odor das plantas e frutos quando neles pulverizados

- Tem ação fitotóxica mais baixa

- Possuí menos efeito acumulativo no solo

- É menos prejudicial as bactérias e outros microorganismos

$\mathrm{O} \mathrm{HCH}$ é bem absorvido pelo trato gastrointestinal, pulmões e pele. $\dot{E}$ transportado quase que totalmente ligado a proteínas plasmáticas e todos os isômeros são preferencialmente estocados no tecido adiposo, mas também em outros órgãos como fígado e glândulas adrenais. O seu metabolismo é hepático e sua excreção se dá pela urina, fezes e leite.

Os diferentes isômeros de $\mathrm{HCH}$ acarretam ações farmacológicas opostas.

O isômero gama é estimulante do Sistema Nervoso Central (SNC), causando violentas convulsões epileptiformes, enquanto os isômeros - alfa, beta e delta são principalmente depressores do SNC, podendo levar a flacidez muscular, prostração e dificuldade de marcha. 
A toxicidade aguda dos isômeros do $\mathrm{HCH}$ verificada em ratos foi em ordem decrescente: gama > alfa > delta > beta, e na toxicidade crônica, obedeceu a ordem: beta > alfa > gama > delta (Smith, A.G., 1991).

A ingestão humana de compostos de $\mathrm{HCH}$ ocorre principalmente através do consumo de alimentos ou exposição ocupacional. A natureza geralmente menos difundida dos isômeros alfa e gama em comparação ao beta é devido à eliminação mais rápida desses isômeros do corpo. Assim como muitos organoclorados persistentes, os niveis de $\mathrm{HCH}$ no corpo tendem a aumentar com a idade (ASTDR, 1990) devido ao seu acumulo.

Os isômeros de hexaclorociclohexano já foram detectados no ar, nas águas de superfícies e subterrânea, em solo e sedimentos, em plantas, em pássaros, peixes e mamiferos. Em humanos, o lindano se concentra principalmente no tecido adiposo. Foi relatado que o lindano e outros compostos organoclorados podem ser transferidos pela rota solo - minhoca - pássaro/ mamífero, causando assim, intoxicação secundária. (Smith 1991)

O lindano, isômero - gama do hexaclorociclohexano, é tóxico para animais, humanos e espécies aquáticas. A intoxicação animal aguda lindano causa aumento da freqüência respiratória, inquietação com um aumento na freqüência urinária, espasmos musculares intermitentes do corpo inteiro, salivação, ranger de dentes e - conseqüente sangramento na boca, movimentos para trás com a perda do equilíbrio e giro do corpo, retração da cabeça, convulsões, respiração ofegante, dentes cerrados, e colapso e morte normalmente no prazo de um dia (Smith 1991).

Efeitos crônicos na saúde podem ocorrer momentos após a exposição ao lindano e podem durar meses ou anos. O lindano causa câncer de fígado, pulmão, glândulas endócrinas e outros tipos em animais (Smith 1991). A superexposição pode causar dano hepático. Os efeitos tóxico crônicos podem também incluir expectativa de vida reduzida, problemas reprodutivos, redução da fertilidade, e mudanças na aparência ou no comportamento .

As ações diferenciadas dos isômeros do hexaclorociclohexano podem produzir efeitos variados em diferentes regiões dos sistemas nervosos e em diferentes espécies de animais.

O hexaclorociclohexano pode ser introduzido no meio ambiente a partir de 
descargas industriais, aplicações de inseticidas ou derramamentos, e pode causar danos significativos. Os efeitos tóxico agudos podem incluir a morte de animais, pássaros, ou peixes, e a morte ou diminuição da taxa de crescimento de plantas (Smith 1991). A carga de inseticida em água de superfície geralmente não atinge concentrações agudamente tóxicas à fauna aquática. No entanto tem alta toxicidade crônica para a vida aquática. Os efeitos das baixas concentrações de inseticidas com freqüência aparecem apenas após períodos de exposição relativamente longos. A exposição crônica a inseticidas, como o lindano, podem apresentar riscos para macroinvertebrados de água doce, mesmo em concentração muito baixas. Os efeitos da baixa concentração podem depender da espécie e da substância e, portanto, não é possivel prevê - los a partir de dados de toxicidade de concentração mais elevadas. (Toledo,H.B., 2002).

$\mathrm{Na}$ Tabela 2 apresenta o grau de toxicidade e de persistência (variando em uma escala de 1 a 5) nos principais grupos de animais atingidos pela contaminação ambiental por agrotóxicos, exceto a espécie humana 
Tabela 2: Toxicidade e persistência ambiental de alguns agrotóxicos (em escala de 1 a 5$)$

\begin{tabular}{lccccc} 
Agrotóxico & Mamíferos & Peixes & Aves & Insetos & $\begin{array}{c}\text { Persistência } \\
\text { no Ambiente }\end{array}$ \\
\hline $\begin{array}{l}\text { Permetrina } \\
\text { Piretróides }\end{array}$ & 2 & 4 & 2 & 5 & 2 \\
\hline DDT & 3 & 4 & 2 & 2 & 5
\end{tabular}

(Organoclo

rados)

$\begin{array}{llllll}\text { Lindana } & 3 & 3 & 2 & 4 & 4\end{array}$

(organoclo

rados)

\begin{tabular}{llllll}
\hline Etil- & 5 & 2 & 5 & 5 & 2
\end{tabular}

paration

(Organofos

forados)

Malation

2

21

4

1

(Organofos

forados)

Carbaril

2

1

1

4

1

(Carbama

tos)

Metoprene

1

1

2

2

(Regulador

crescimen

to)

Bacilus

1

1

1

1

1

thuringenis

(Microbial)

Fonte: WHO, 1990. 


\subsection{Analise Cromatográfica}

Dentre os modernos métodos de análise química, a cromatografia ocupa, sem dúvida, um lugar de merecido destaque no que concerne à separação, identificação e quantificação de espécies químicas.

Cromatografia é um método físico-químico de separação, no qual os componentes a serem separados são distribuídos entre duas fases: uma fase fixa de grande área superficial denominada fase estacionária, e a outra um fluido que percola através dela sendo, por isto, denominada fase móvel. (Ciola,1985).

\subsubsection{CLASSIFICAÇÃO DOS MÉTODOS CROMATOGRÁFICOS}

Os critérios para a classificação dos diferentes métodos cromatográficos variam de acordo com o enfoque de cada autor, sendo os mais comuns: quanto ao mecanismo da separação, quanto à técnica empregada e em relação ao tipo de fase utilizada.

\subsubsection{PARÂMETROS}

Teoria básica da cromatografia gasosa, com ênfase em parâmetros como: Área do Pico, Tempo de Retenção e Posição do Pico. Os quais podem ser considerados, do ponto de vista prático, os fatores que governam o sucesso da separação cromatográfica.

\subsubsection{GÁS DE ARRASTE}

A função do gás de arraste é levar as moléculas da amostra a ser separada do ponto de injeção até o detector, passando pela coluna onde a separação irá ocorrer. Idealmente, deve apresentar as seguintes caracteristicas:

a) não interagir com a fase estacionária nem com a amostra;

b) ter baixo custo;

c) ser adequado ao detector em uso. 


\subsubsection{INJETOR}

A escolha apropriada das condições de injeção, tais como o volume da amostra, temperatura do injetor e tipo de injeção dependem, em larga escala, do estado físico da amostra.

\subsubsection{COLUNA}

A coluna é considerada como o "o coração do sistema cromatográfico", uma vez que nela que a separação irá ocorrer. A escolha da coluna apropriada para uma dada separação é de suma importância e, muitas vezes, difícil.

\subsubsection{DETECTOR}

A função do detector em um sistema cromatográfico é acusar a presença e medir a quantidade de componentes no efluente da coluna.

Dentre as diversas características desejáveis para um bom detector, as principais são: sensibilidade elevada, baixo nível de ruído, resposta, ampla faixa de linearidade e quantidade mínima detectada.

\subsubsection{DETECÇÃO POR CAPTURA DE ELÉTRONS - ECD}

$O$ detector por captura eletrônica tem seu funcionamento baseado na captura de elétrons pela amostra, elétrons estes gerados pela ionização do gás de arraste por uma fonte radioativa.

Á medida em que o gás de arraste (geralmente nitrogênio) fluí através do detector, uma lâmina contendo a fonte radioativa $(\mathrm{H}$ ou $\mathrm{Ni}$ ) ioniza as moléculas do gás e forma elétrons lentos. Os elétrons são atraídos para o anodo, o qual encontrase com +90 volts em relação ao cátodo. Como conseqüência, este fluxo de elétrons irá gerar uma corrente constante também conhecida como corrente padrão. Uma molécula contendo grupos que apresentam afinidade por elétrons sendo eluída da coluna junto com o gás de arraste, ao passar pelo detector irá capturar os elétrons livres produzidos na ionização do gás de arraste. Como conseqüência, isto irá diminuir a corrente e ocasionar o aparecimento de um pico negativo (na prática observa-se picos positivos regulares, uma vez que a polaridade do registrador é invertida). 
Através de uma calibração apropriada pode-se determinar a concentração da amostra presente, com base na queda da corrente.

A fonte radioativa utilizada na ionização deve ser escolhida adequadamente. Apesar de existir uma larga gama de radioisótopos passíveis de uso, apenas o trítio (mais antigo) ou Ni são utilizados em aparelhos comerciais. Como o Ni pode ser aquecido até cerca de $350^{\circ} \mathrm{C}$, a possibilidade de descontaminação do detector (das sujeiras não radioativas) é maior.

Por outro lado, a energia da partícula beta emitida pelo ${ }^{63} \mathrm{Ni}$ é quase quatro vezes mais energética, e sua meia vida é 10 vezes superior, o que aumenta o risco do operador em caso de contaminação do sistema com o material radioativo (geralmente utiliza-se $8 \mathrm{~m} \mathrm{Ci} \mathrm{de}{ }^{63} \mathrm{Ni}$, uma atividade considerável).

Algumas características importantes dos dois isótopos, as quais devem ser ponderadas pelo usuário no momento da escolha do detector, estão apresentadas na Tabela 1. 
Tabela 3: Comparação das características entre fonte radioativas de Hidrogênio $\left({ }^{3} \mathrm{H}\right)$ e Niquel $\left({ }^{63} \mathrm{Ni}\right)$.

\begin{tabular}{lll}
\multicolumn{1}{c}{ Caracteristica } & ${ }^{3} \mathrm{H}$ & ${ }^{63} \mathrm{Ni}$ \\
\hline Meia-Vida & 12,5 anos & 125 anos \\
\hline Tipo de decaimento & $\beta^{-}$ & $\beta$ \\
\hline Energia de pärícula & $18 \mathrm{kev}$ & $67 \mathrm{kev}$ \\
\hline Atividade especifica & $9.800 \mathrm{Ci} / \mathrm{g}$ & $5 \mathrm{Ci} / \mathrm{g}$ \\
\hline Estado físico (CNTP) & gás & Sólido \\
\hline Limite de tempertura para uso & $220^{\circ} \mathrm{C}$ & $350^{\circ} \mathrm{C}$ \\
no ECD & & \\
\hline Radiotoxidez & Alta & Moderada \\
\hline
\end{tabular}

\section{DESCRICÃO DO DETECTOR}

Os elétrons coletados após a ionização do gás de arraste pela fonte radioativa, ao serem capturados pela amostra irão gerar um sinal elétrico. Este sinal é enviado a um eletrômetro que o amplifica e remete ao registrador para desenhar o cromatograma. 


\section{MATERIAIS E METODOS}

\subsection{Matriz Estudada}

No ser humano, os organoclorados podem ser identificados no sangue, no soro, no plasma, no tecido adiposo e no leite. No Brasil, o uso geral desse pesticida foi proibido em 1985, ficando o mesmo restrito apenas a campanhas de saúde pública (Portaria do Ministério da Agricultura $n^{\circ} 329$ de 2.9.1985).

Neste trabalho analisamos o soro sangüíneo de 56 funcionários e ex funcionários classificados como grupo 1 e outro grupo composto de 112 pessoas não exposto ao produto estudado classificado como grupo 2 em uma proporção de $1: 2$

O soro sangüíneo das amostras foram coletados no local e encaminhado imediatamente ao laboratório - Seção de aditivos e Pesticidas Residuais do Instituto Adolfo Lutz, São Paulo/SP para analise.

As amostras chegaram em tubos devidamente identificados e lacrados resfriadas e com gelo reciclado em uma caixa de isopor. 


\subsection{Ativo Estudado}

Nas figuras de 1 a 8 estão sendo apresentadas as formulas química, estrutural e seus respectivos cromatogramas em destaque o tempo de retenção

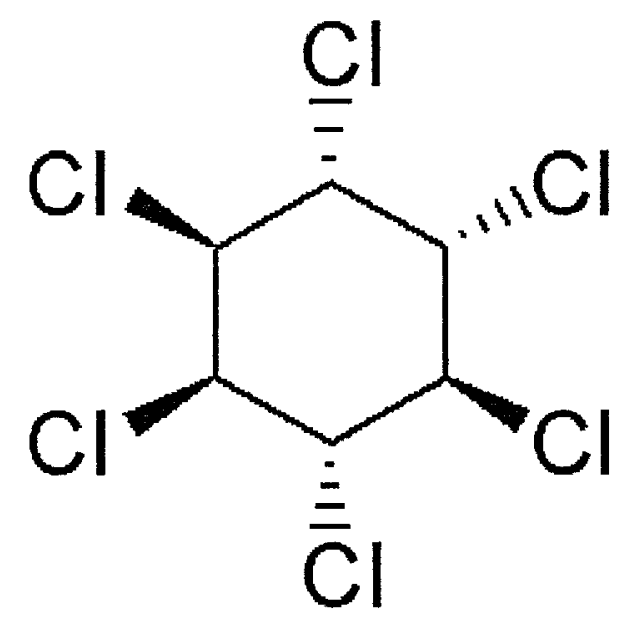

Figura 1: Formula Estrutural Alfa $\mathrm{HCH}$.

Fórmula Molecular $\mathrm{C}_{6} \mathrm{H}_{6} \mathrm{Cl}_{6}$ e peso molecular $290,80 \mathrm{~g} \mathrm{~mol}^{-1}$

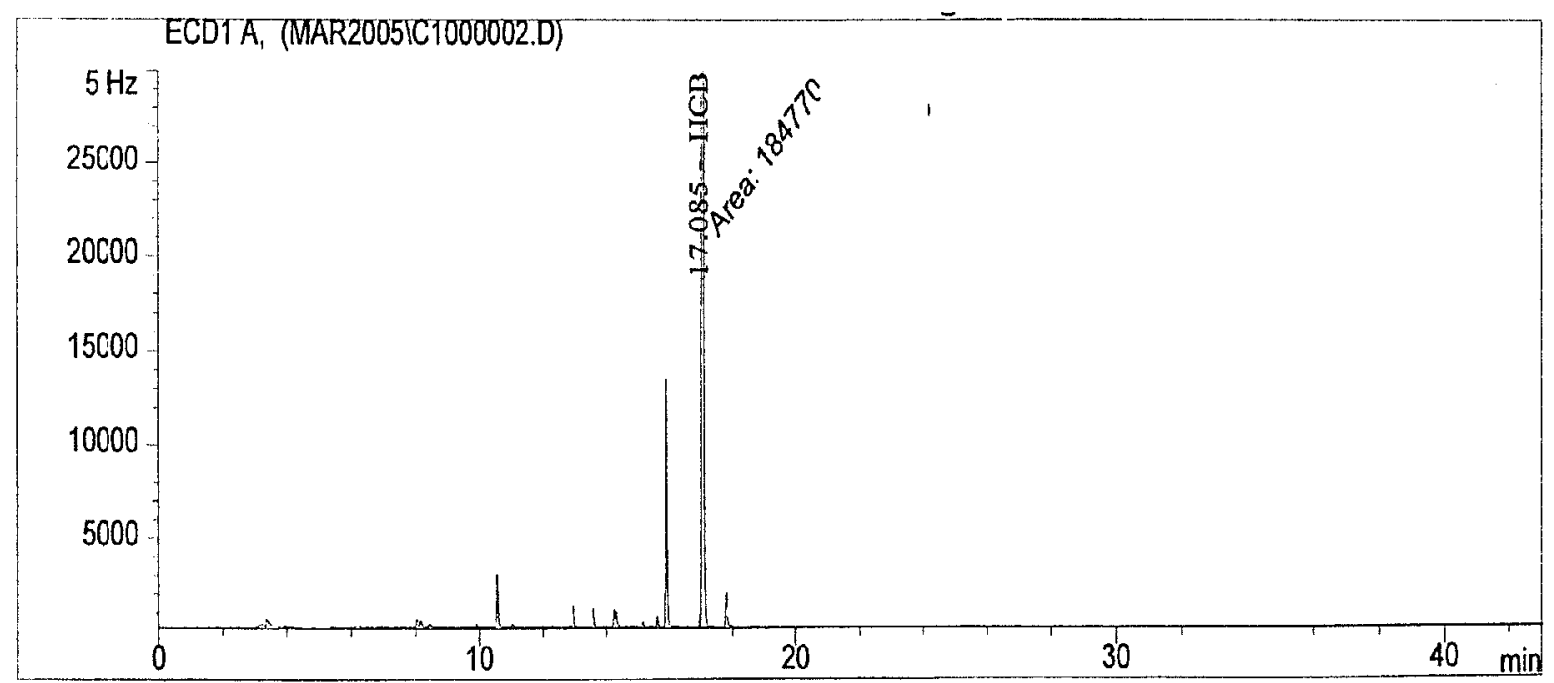

Figura 2: Cromatograma Alfa HCH, tempo de retenção 17.085 minutos. 


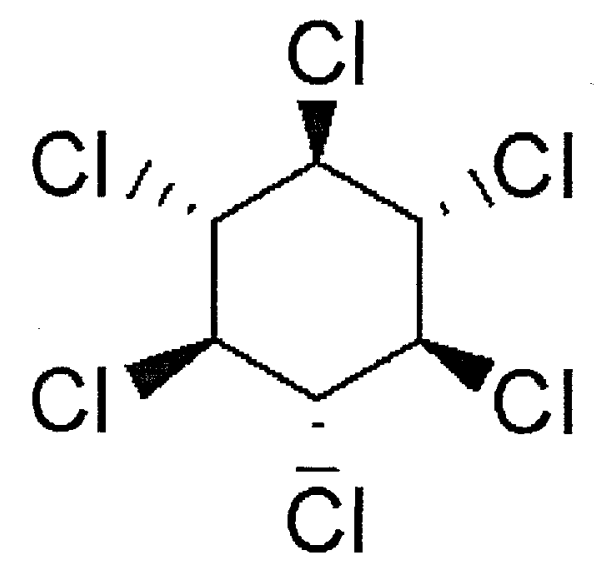

Figura 3: Formula Estrutural Beta $\mathrm{HCH}$.

Formula Molecular $\mathrm{C}_{6} \mathrm{H}_{6} \mathrm{Cl}_{6}$ e peso molecular $290,80 \mathrm{~g} \mathrm{~mol}^{-1}$

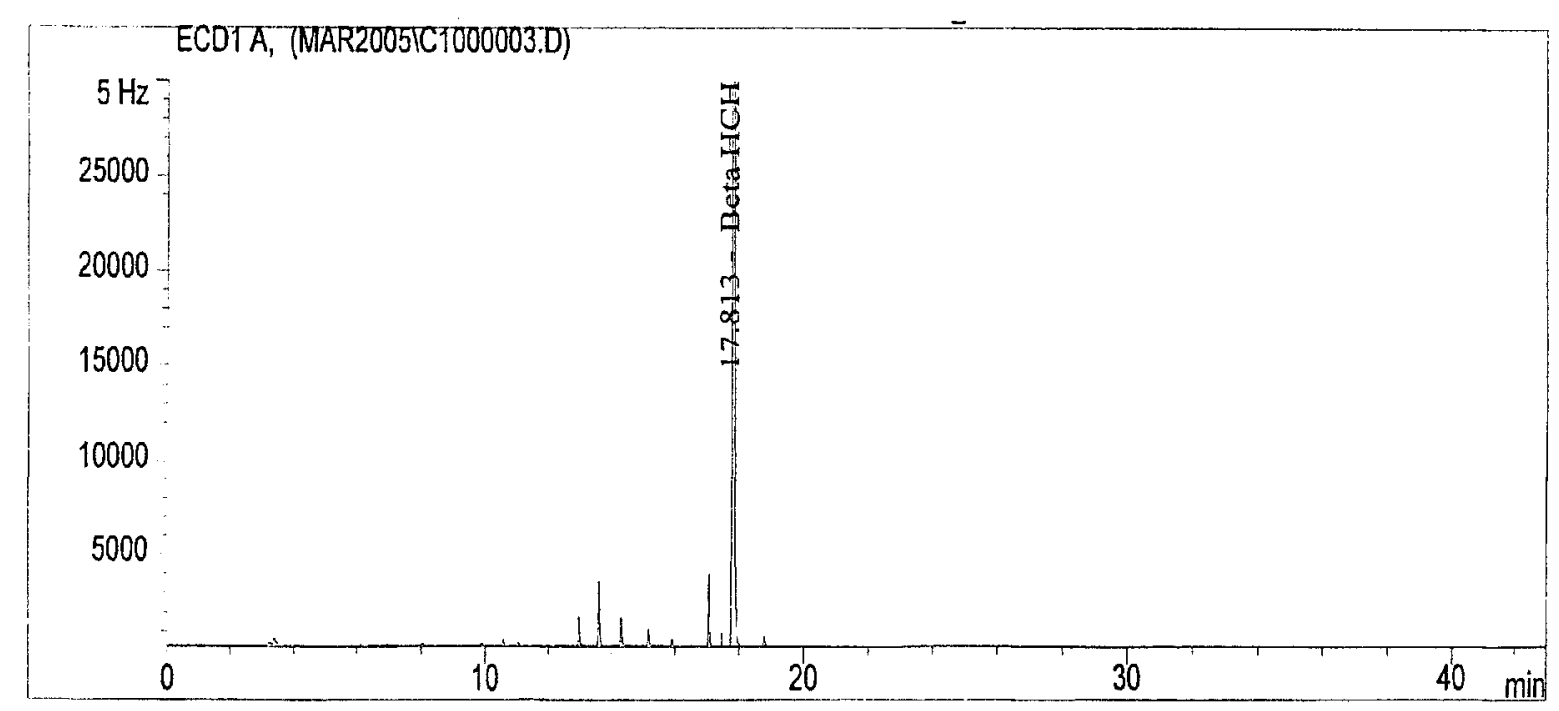

Figura 4: Cromatograma Beta $\mathrm{HCH}$ tempo de retenção 17.813 minutos. 


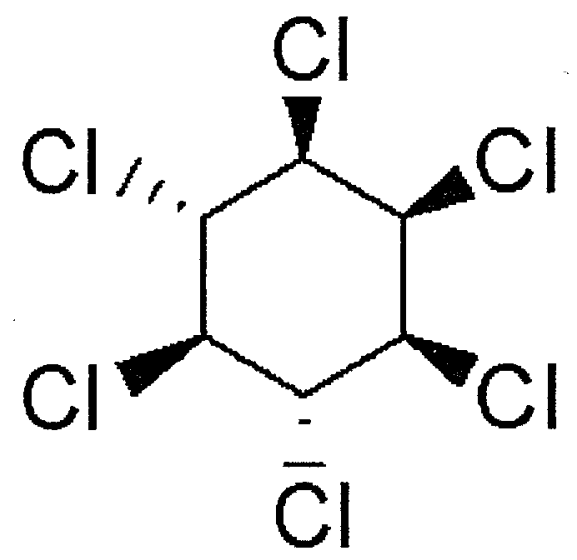

Figura 5: Formula Estrutural Delta $\mathrm{HCH}$.

Formula Molecular $\mathrm{C}_{6} \mathrm{H}_{6} \mathrm{Cl}_{6}$ e peso molecular $290,80 \mathrm{~g} \mathrm{~mol}^{-1}$

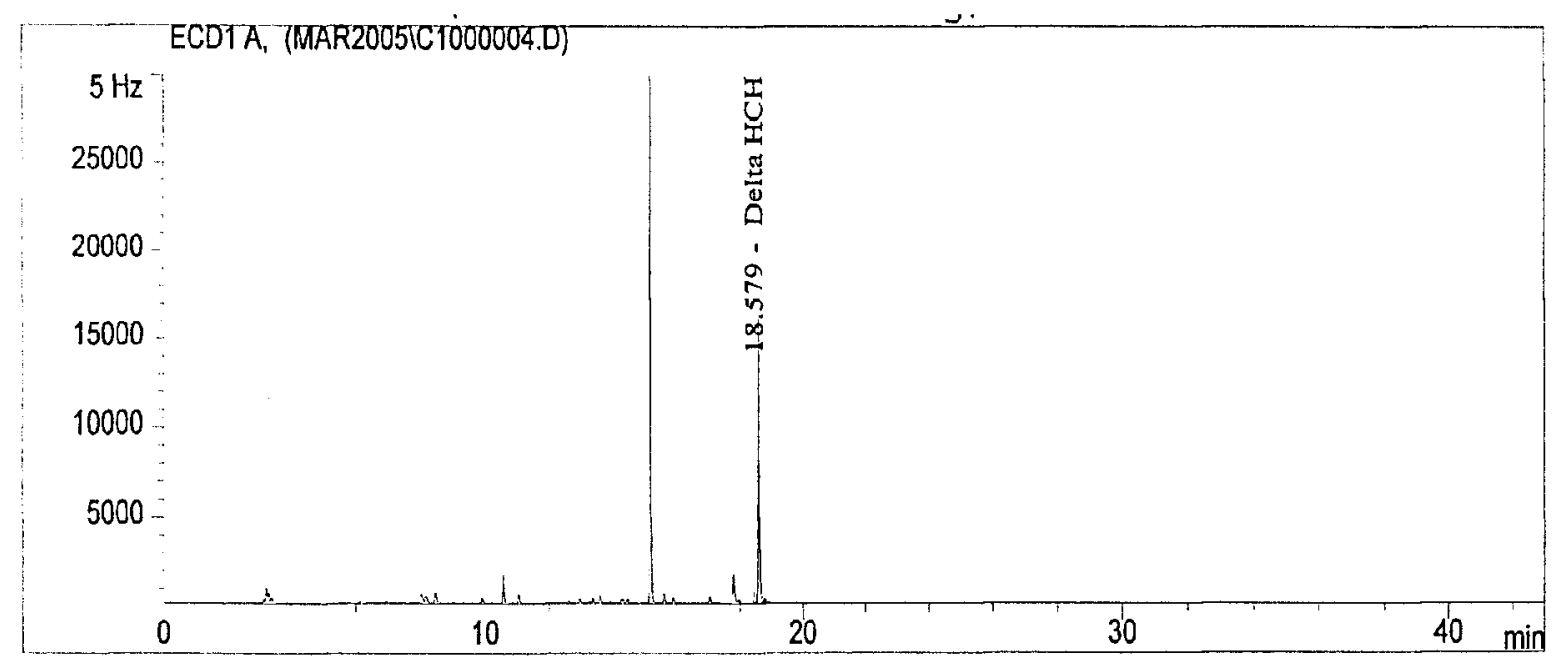

Figura 6: Cromatograma Delta $\mathrm{HCH}$ tempo de retenção 18.579 minutos. 


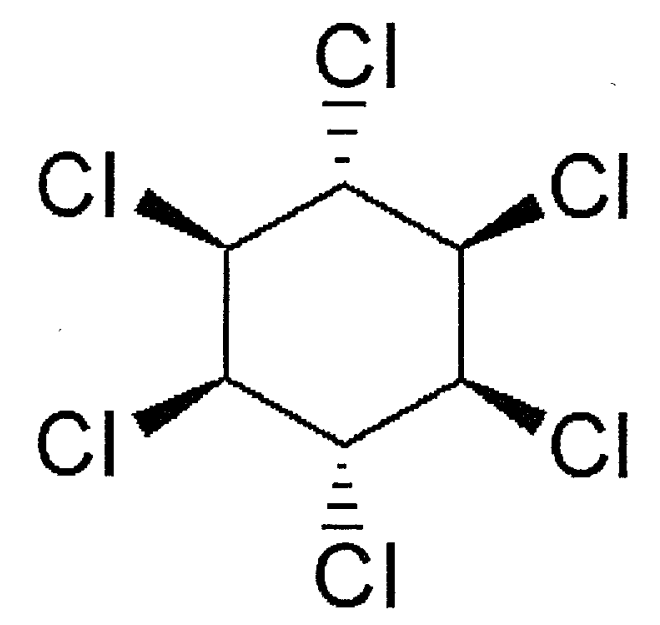

Figura 7: Formula Estrutural Gama $\mathrm{HCH}$ - Lindana.

Formula Molecular $\mathrm{C}_{6} \mathrm{H}_{6} \mathrm{Cl}_{6}$ e peso molecular $290,80 \mathrm{~g} \mathrm{~mol}^{-1}$

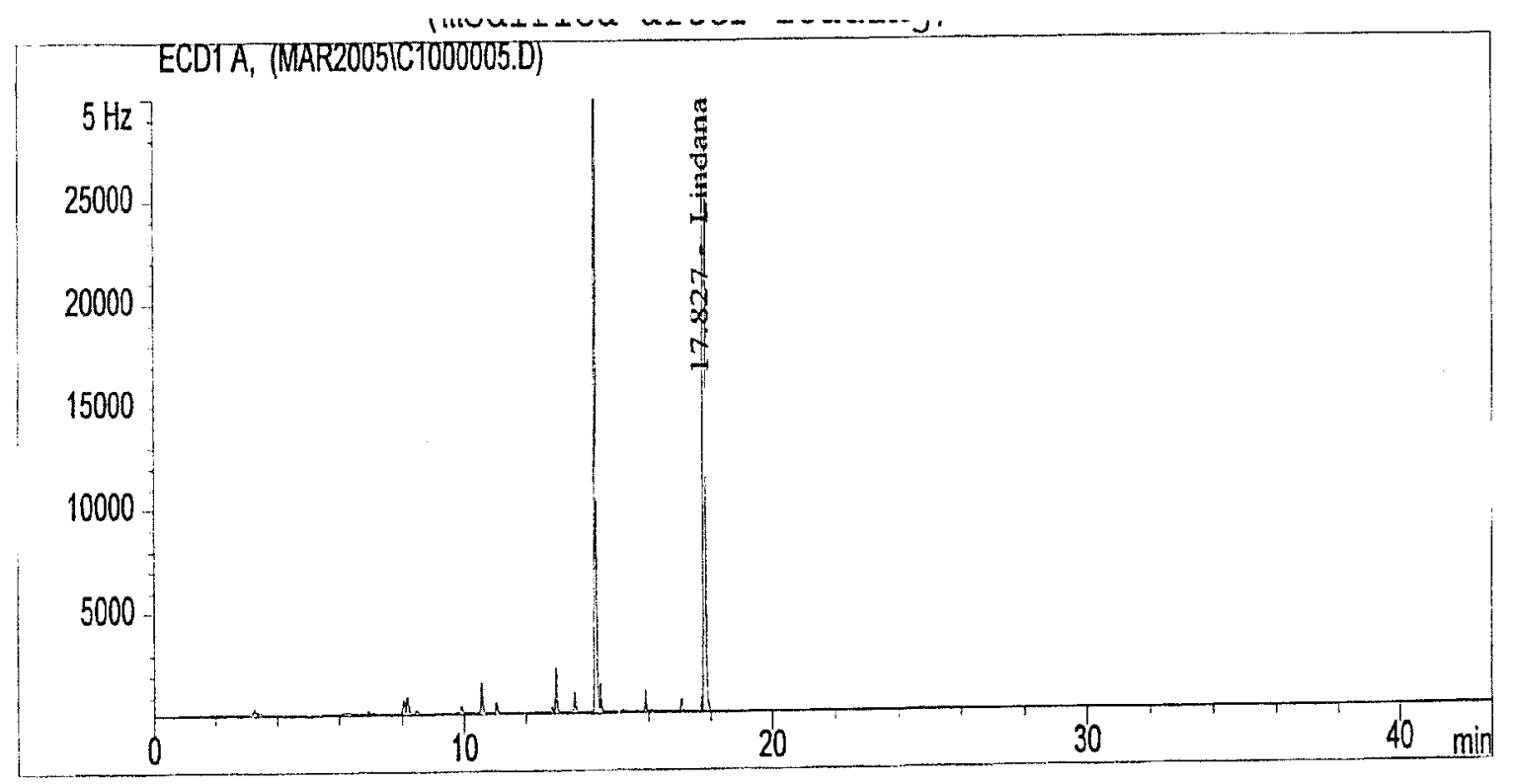

Figura 8: Cromatograma Gama HCH - Lindana tempo de retenção 17.827 minutos. 


\subsection{Principio do método analítico}

Resíduos de Hexaclorociclohexano (isômeros alfa, beta, delta e gama) são extraídos com hexano após a homogeneização do soro sangüíneo resfriado. Após concentração do extrato, é injetado no cromatógrafo á gás com detector de captura de elétrons GC-ECD.

\subsection{Equipamentos, materiais e solventes utilizados}

\subsubsection{Equipamentos}

a) Cromatógrafo á gás com Detector de Captura de Elétrons, marca Agilent modelo 6890

b) Injetor automático Agilent,

c) Software ChemStation,

d) Balança Analítica, marca Sartorius,

e) Balança Semi Analítica,

f) Agitador de tubos,

g) Lavadora ultrasônica,

h) Purificador de água com filtro Milli-Q, marca Millipore

i) Concentrador com fluxo de gás.

\subsubsection{Vidraria e outros materiais}

a) Tubos de vidro com tampa esmerilhada graduado de $15 \mathrm{~mL}$

b) Proveta graduada de $50 \mathrm{~mL}$,

c) Balão volumétrico de $10 \mathrm{~mL}$,

d) Pipetas volumétricas e graduadas de diversos volumes,

e) Frasco de vidro para injetor automático de $2 \mathrm{~mL}$, 


\subsubsection{Solventes e Reagentes}

a) Água purificada,

b) Acetona grau residuos ou similar,

c) Hexano grau resíduos,

d) Isooctano grau resíduos.

\subsection{Preparação das Soluções}

\subsubsection{Preparação das Soluções de Estoque "Solução Mãe".}

a) Solução ALFA: $100,0 \mu g \cdot \mathrm{mL}^{-1}$ de $\alpha \mathrm{HCH}$

Pesar 0,0100g de a HCH (Padrão Primário) e dissolver em isooctano.

Transferir para balão volumétrico de $100 \mathrm{~mL}$ completando o volume com isooctano.

b) Solução BETA: $100,0 \mu g \cdot \mathrm{mL}^{-1}$ de $\beta \mathrm{HCH}$

Pesar $0,0100 \mathrm{~g}$ de $\beta \mathrm{HCH}$ (Padrão Primário) e dissolver em isooctano.

Transferir para balão volumétrico de $100 \mathrm{~mL}$ completando o volume com isooctano.

c) Solução DELTA: $100,0 \mu g \cdot \mathrm{mL}^{-1}$ de $\sigma \mathrm{HCH}$

Pesar $0,0100 \mathrm{~g}$ de $\sigma \mathrm{HCH}$ (Padrão Primário) e dissolver em isooctano.

Transferir para balão volumétrico de $100 \mathrm{~mL}$ completando o volume com isooctano.

d) Solução GAMA "LINDANO": $100,0 \mu g \cdot \mathrm{mL}^{-1}$ de $\gamma \mathrm{HCH}$

Pesar 0,0100g de Lindano (Padrão Primário) e dissolver em isooctano.

Transferir para balão volumétrico de $100 \mathrm{~mL}$ completando o volume com isooctano.

\subsubsection{Preparação das Soluções Intermediaria "SI".}

e) Solução SI-A: $1000 \rho g . \mu \mathrm{L}^{-1}$ de ALFA

Transferir $100 \mu \mathrm{L}$ da solução ALFA para um balão volumétrico de $10,0 \mathrm{~mL}$. 
Completar o volume com hexano.

f) Solução SI-B: $1000 \rho g \cdot \mu L^{-1}$ de BETA

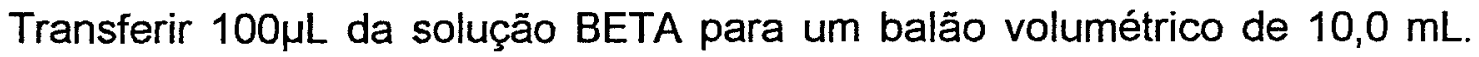
Completar o volume com hexano.

g) Solução SI-C: $1000 \rho g \cdot \mu \mathrm{L}^{-1}$ de DELTA

Transferir $100 \mu \mathrm{L}$ da solução DELTA para um balão volumétrico de $10,0 \mathrm{~mL}$. Completar o volume com hexano.

h) Solução SI-D: $1000 \rho g \cdot \mu L^{-1}$ de LINDANA

Transferir $100 \mu \mathrm{L}$ da solução GAMA "LINDANA" para um balão volumétrico de $10,0 \mathrm{~mL}$. Completar o volume com hexano.

\subsubsection{Preparação das soluções para obtenção das Curvas de Calibrações.}

Curva 1- Solução B) Alfa $\mathrm{HCH}+$ Beta $\mathrm{HCH}$

a) Solução (B): $100+200 \rho g \mu \mathrm{L}^{-1}$ de Alfa + Beta

Transferir $100 \mu \mathrm{L}$ da SI-A $+200 \mu \mathrm{L}$ da SI-B para um balão volumétrico e completar o volume para $10 \mathrm{~mL}$ com hexano.

b) Solução (B): $50+100 \rho g \mu \mathrm{L}^{-1}$ de Alfa + Beta

Transferir $5 \mathrm{~mL}$ da Solução (B): $100+200 \rho g \mu \mathrm{L}^{-1}$ de Alfa + Beta para um balão volumétrico e completar o volume para $10 \mathrm{~mL}$ com hexano.

c) Solução (B): $20+40 \rho g \mu \mathrm{L}^{-1}$ de Alfa + Beta

Transferir $20 \mu \mathrm{L}$ da SI-A $+20 \mu \mathrm{L}$ da SI-B para um balão volumétrico e completar o volume para $10 \mathrm{~mL}$ com hexano.

d) Solução (B): $10+20 \rho g \mu \mathrm{L}^{-1}$ de Alfa + Beta

Transferir $1 \mathrm{~mL}$ da Solução (B): $100+200 \rho g \mu \mathrm{L}^{-1}$ de Alfa + Beta para um balão volumétrico e completar o volume para $10 \mathrm{~mL}$ com hexano.

e) Solução (B): $2+4 \rho g \mu \mathrm{L}^{-1}$ de Alfa + Beta

Transferir $1 \mathrm{~mL}$ da Solução (B) $20+40 \rho g \mathrm{~L}^{-1}$ de Alfa + Beta para um balão 
volumétrico e completar o volume para $10 \mathrm{~mL}$ com hexano.

f) Solução (B): $1+2 \rho g \mu \mathrm{L}^{-1}$ de Alfa + Beta

Transferir $1 \mathrm{~mL}$ da Solução (B) $10+20 \rho g \mu \mathrm{L}^{-1}$ de Alfa + Beta para um balão volumétrico e completar o volume para $10 \mathrm{~mL}$ com hexano.

g) Solução (B): 0,2+0,4 pg $\mu \mathrm{L}^{-1}$ de Alfa + Beta

Transferir $1 \mathrm{~mL}$ da Solução (B) $2+4 \rho g \mu \mathrm{L}^{-1}$ de Alfa + Beta para um balão volumétrico e completar o volume para $10 \mathrm{~mL}$ com hexano.

h) Solução (B): 0,1+0,2 pg $\mu \mathrm{L}^{-1}$ de Alfa + Beta

Transferir $1 \mathrm{~mL}$ da Solução (B) $1+2 \rho g \mu \mathrm{L}^{-1}$ de Alfa + Beta para um balão volumétrico e completar o volume para $10 \mathrm{~mL}$ com hexano.

Curva 2- Solução (A) Lindana + Delta HCH

i) Solução (A): $100+200 \rho g \mathrm{~L}^{-1}$ de Lindana + Delta HCH

Transferir $100 \mu \mathrm{L}$ da SI-D + $200 \mu \mathrm{L}$ da SI-C para um balão volumétrico e completar o volume para $10 \mathrm{~mL}$ com hexano.

j)Solução (A): $50+100 \rho g \mathrm{~L}^{-1}$ de Lindana + Delta $\mathrm{HCH}$

Transferir $5 \mathrm{~mL}$ da Solução (A): $100+200 \rho g \mu \mathrm{L}^{-1}$ de Lindana + Delta HCH para um balão volumétrico e completar o volume para $10 \mathrm{~mL}$ com hexano.

k) Solução (A): $20+40 p g \mu \mathrm{L}^{-1}$ de Lindana + Delta $\mathrm{HCH}$

Transferir $20 \mu \mathrm{L}$ da SI-D $+20 \mu \mathrm{L}$ da SI-C para um balão volumétrico e completar o volume para $10 \mathrm{~mL}$ com hexano.

I) Solução (A): $10+20 \rho g \mathrm{~L}^{-1}$ de Lindana + Delta $\mathrm{HCH}$

Transferir $1 \mathrm{~mL}$ da Solução (A): $100+200 \rho g \mathrm{LL}^{-1}$ de Lindana + Delta HCH para um balão volumétrico e completar o volume para $10 \mathrm{~mL}$ com hexano.

m) Solução (A): $2+4 \rho g \mu \mathrm{L}^{-1}$ de Lindana + Delta $\mathrm{HCH}$

Transferir $1 \mathrm{~mL}$ da Solução (A) $20+40 \rho g \mathrm{~L}^{-1}$ de Lindana + Delta HCH para 
um balão volumétrico e completar o volume para $10 \mathrm{~mL}$ com hexano.

n) Solução (A): $1+2 \rho g \mathrm{~L}^{-1}$ de Lindana + Delta $\mathrm{HCH}$

Transferir $1 \mathrm{~mL}$ da Solução (A) $10+20 \rho g \mathrm{~L}^{-1}$ de Lindana + Delta $\mathrm{HCH}$ para um balão volumétrico e completar o volume para $10 \mathrm{~mL}$ com hexano.

o) Solução (A): $0,2+0,4 \rho g \mu L^{-1}$ de Lindana + Delta $\mathrm{HCH}$

Transferir $1 \mathrm{~mL}$ da Solução (A) $2+4 \rho g \mu \mathrm{L}^{-1}$ de Lindana + Delta HCH para um balão volumétrico e completar o volume para $10 \mathrm{~mL}$ com hexano.

p) Solução (A): 0,1+0,2 pg $\mu \mathrm{L}^{-1}$ de Lindana + Delta $\mathrm{HCH}$

Transferir $1 \mathrm{~mL}$ da Solução (A) $1+2 \rho g \mu \mathrm{L}^{-1}$ de Lindana + Delta HCH para um balão volumétrico e completar o volume para $10 \mathrm{~mL}$ com hexano.

Nas figuras 9 ate 14 são apresentados alguns dos cromatogramas das curvas de calibração. 
Alfa $\mathrm{HCH}=10 \mathrm{pg} / \mathrm{uL}$

Beta $\mathrm{HCH}, \mathrm{Aldrin}$, Dieldrin $=20 \mathrm{pg} / \mathrm{uL}$

Endrin, op'DDE $=40 \mathrm{pg} / \mathrm{uL}$

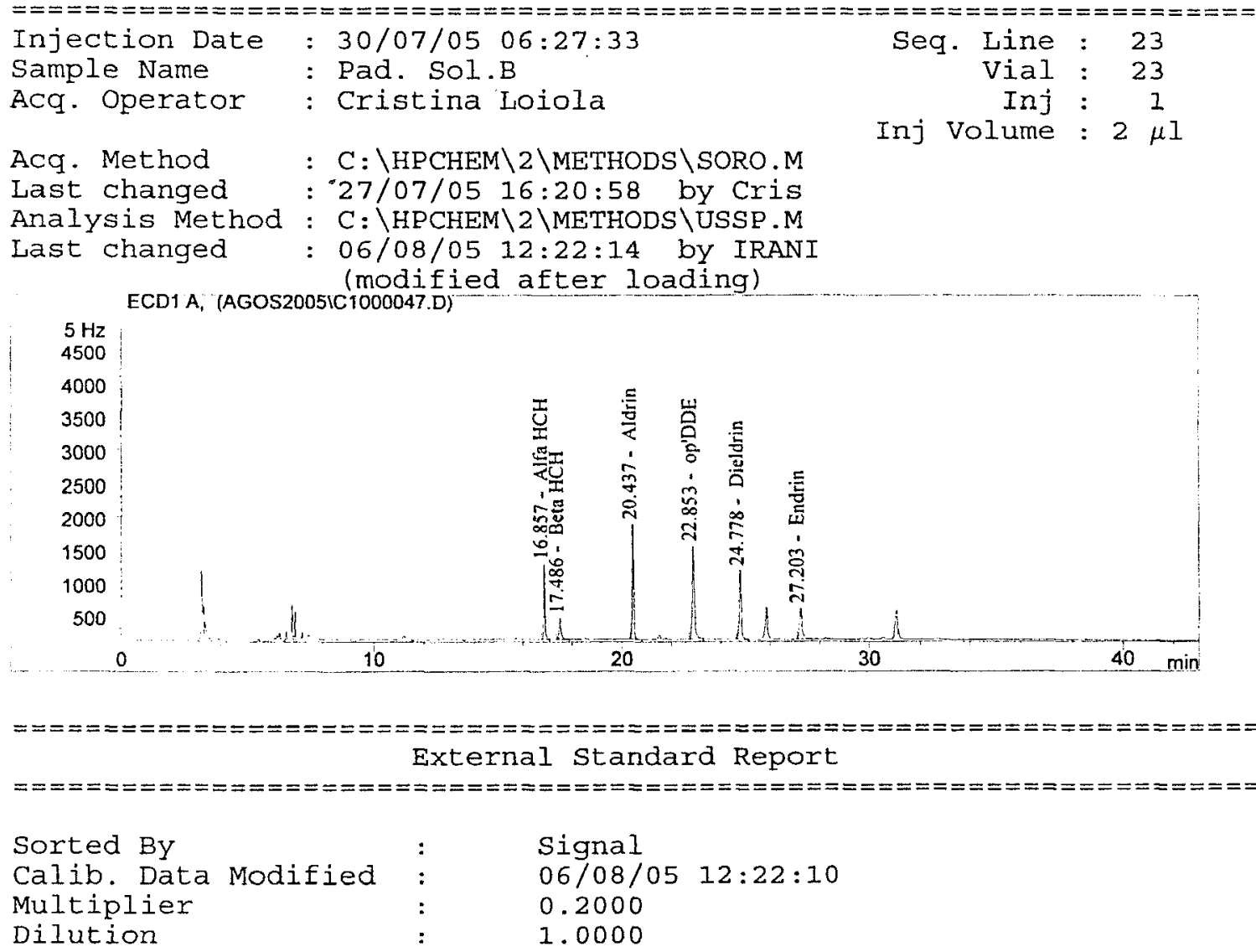

Signal 1: $\operatorname{ECD1} A$,

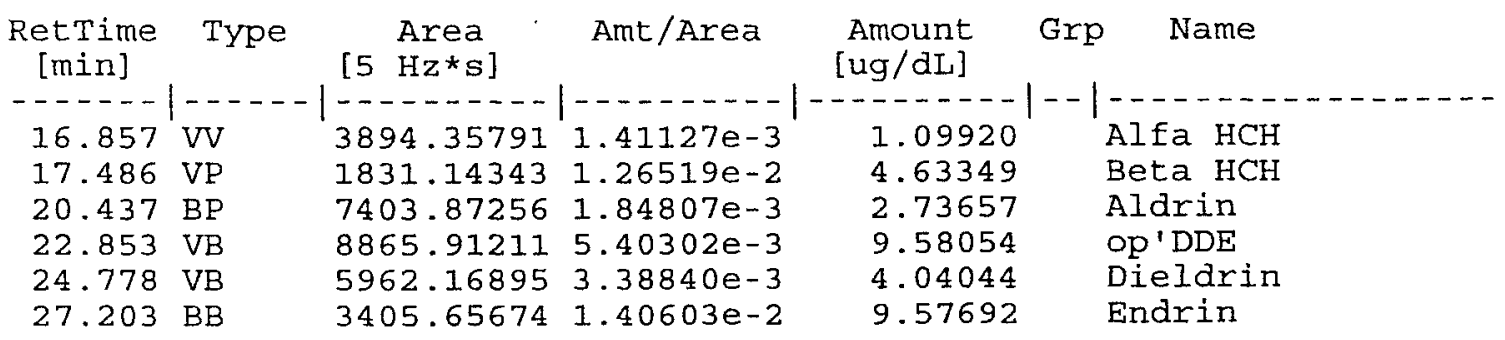

Totals :

31.66716

Results obtained with enhanced integrator!

*** End of Report

Figura 9: Cromatograma da Curva 1- Solução "B" Alfa HCH + Beta $\mathrm{HCH}$ Concentração $10 \rho g \mathrm{~L}^{-1}$ Alfa $\mathrm{HCH}$ e $20 \mathrm{pg} \mu \mathrm{L}^{-1}$ Beta $\mathrm{HCH}$ 
Alfa $\mathrm{HCH}=50 \mathrm{pg} / \mathrm{uL}$

Beta $\mathrm{HCH}, \mathrm{Aldrin}$, Dieldrin $=100 \mathrm{pg} / \mathrm{uL}$

Endrin, op'DDE $=200 \mathrm{pg} / \mathrm{uL}$

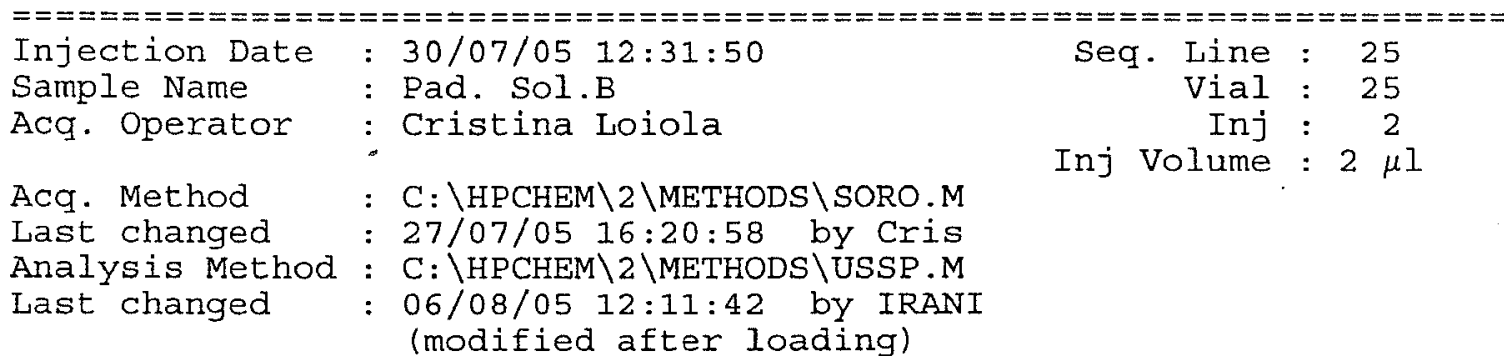
ECD1 A, (AGOS2005IC1000054.D)

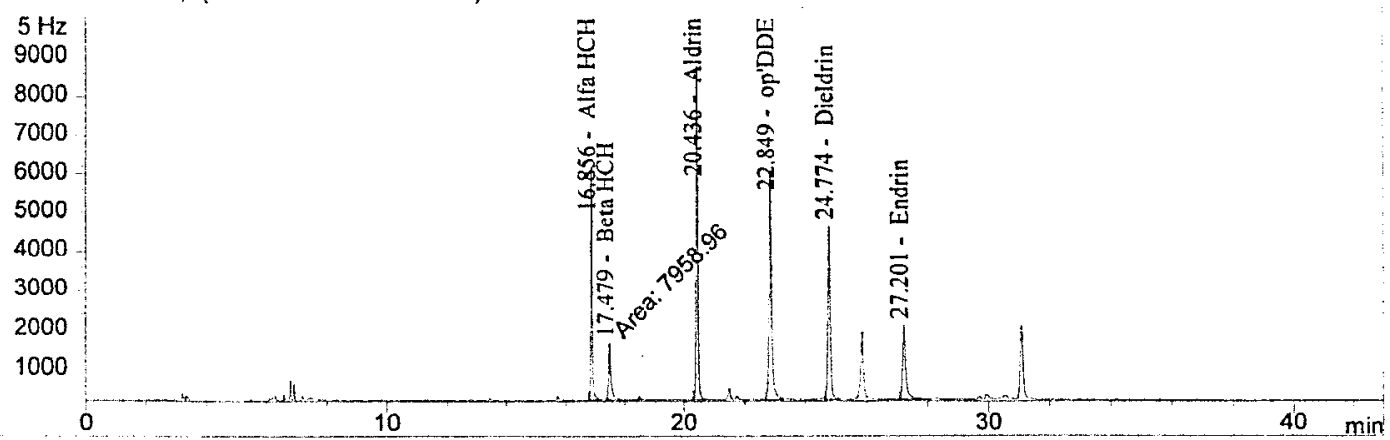

External standard Report

Sorted BY

Calib. Data Modified

Multiplier

Dilution
Signal

06/08/05 12:11:00

0.2000

1.0000

Signal 1: $\operatorname{ECD} 1 \mathrm{~A}$,

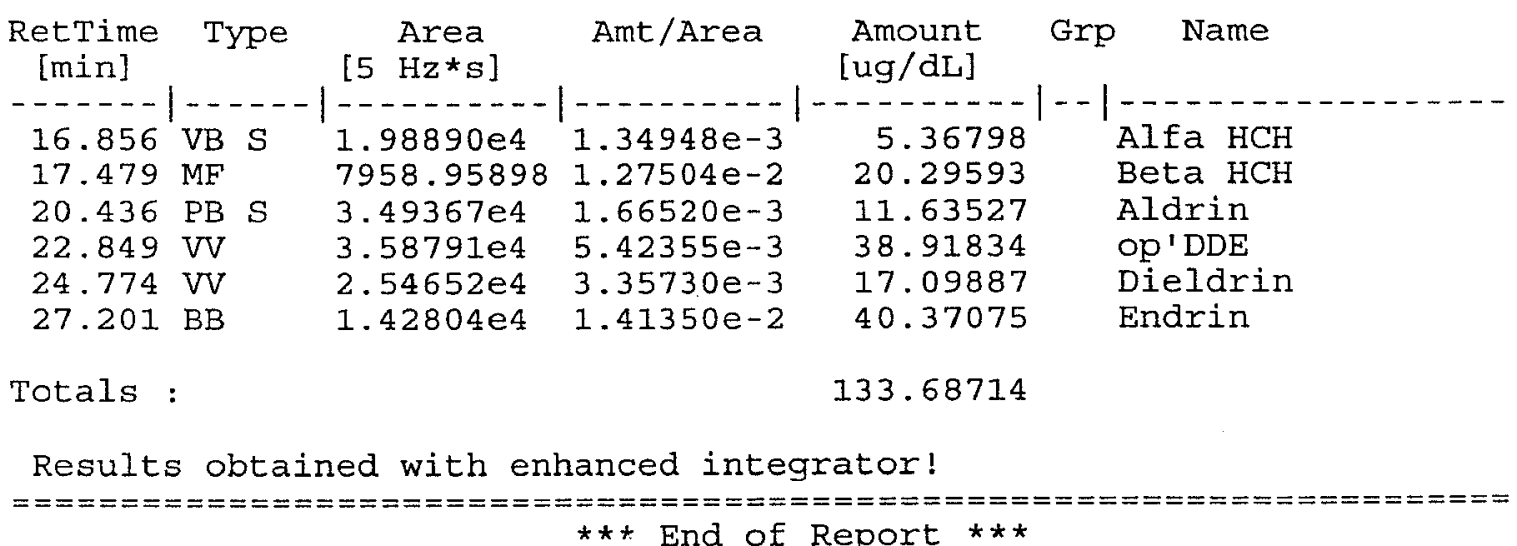

Figura 10: Cromatograma da Curva 1- Solução "B" Alfa $\mathrm{HCH}+$ Beta $\mathrm{HCH}$ Concentração $50 p g \mathrm{~L}^{-1}$ Alfa $\mathrm{HCH}$ e $100 \rho g \mu \mathrm{L}^{-1}$ Beta $\mathrm{HCH}$ 
Alfa $\mathrm{HCH}=100 \mathrm{pg} / \mathrm{uL}$

Beta $\mathrm{HCH}$, Aldrin, Dieldrin $=200 \mathrm{pg} / \mathrm{uL}$

Endrin, op'DDE $=400 \mathrm{pg} / \mathrm{uL}$

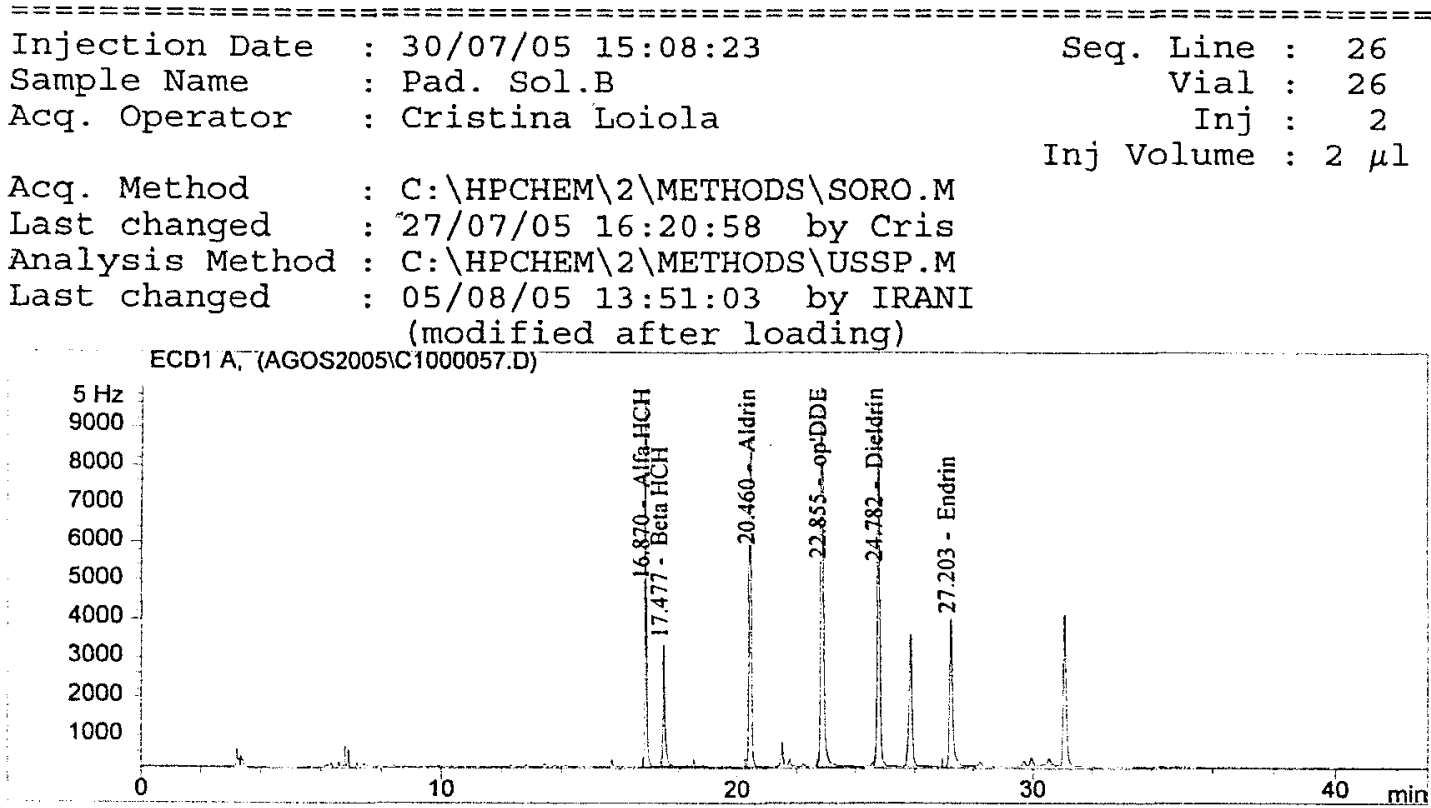

External Standard Report

Sorted By

Calib. Data Modified

Multiplier

Dilution

Signal 1: ECD1 A,
Signal

Friday, 5 5e August 5e 2005 13:50:58

0.2000

1.0000

\begin{tabular}{|c|c|c|c|c|c|}
\hline $\begin{array}{l}\text { RetTime } \\
\text { [min] }\end{array}$ & Type & {$\left[\begin{array}{ll}\text { Area } \\
{[5} & \mathrm{Hz} * \mathrm{~S}\end{array}\right]$} & Amt / Area & $\begin{array}{l}\text { Amount } \\
\text { [ug/dL] }\end{array}$ & Name \\
\hline---- & ---- & $\ldots \ldots$ & --------1 & -8 & $1-\cdots$ \\
\hline $\begin{array}{l}16.870 \\
17.477\end{array}$ & $\begin{array}{ll}\text { VB } & S \\
V V & T\end{array}$ & $\begin{array}{l}8.36646 \mathrm{e} 4 \\
1.54086 \mathrm{e} 4\end{array}$ & $\begin{array}{l}1.27630 \mathrm{e}-3 \\
1.29886 \mathrm{e}-2\end{array}$ & $\begin{array}{l}21.35630 \\
40.02738\end{array}$ & $\begin{array}{ll}\text { Alfa } & \mathrm{HCH} \\
\text { Beta } & \mathrm{HCH}\end{array}$ \\
\hline 20.460 & $\mathrm{~PB} S$ & $1.18671 \mathrm{e} 5$ & $1.70951 \mathrm{e}-3$ & 40.57372 & Aldrin \\
\hline 22.855 & VB $S$ & $7.47481 e 4$ & $5.41685 e-3$ & 80.97984 & $O P^{\prime} D D E$ \\
\hline 24.782 & VB $S$ & $7.76671 \mathrm{e} 4$ & $3.07248 e-3$ & 47.72616 & Dieldrin \\
\hline 27.203 & VV & $2.83772 e 4$ & $1.43226 \mathrm{e}-2$ & 81.28696 & Endrin \\
\hline
\end{tabular}

Totals :

311.95037

Results obtained with enhanced integrator!

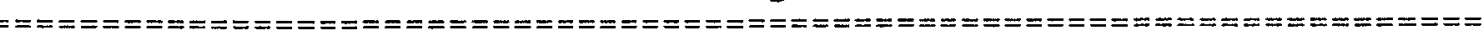
** End of Report ***

Figura 11: Cromatograma da Curva 1- Solução "B" Alfa $\mathrm{HCH}+$ Beta $\mathrm{HCH}$ Concentração $100 \rho g \mathrm{~L}^{-1}$ Alfa $\mathrm{HCH}$ e $200 \rho g \mu \mathrm{L}^{-1}$ Beta $\mathrm{HCH}$ 
$\mathrm{HCB}$, Lindana $=10 \mathrm{pg} / \mathrm{uL}$

Delta HCH, pp'DDE $=20 \mathrm{pg} / \mathrm{uL}$

$\mathrm{pP}^{\prime} \mathrm{DDT}, \mathrm{op} \mathrm{pDT}^{\prime}=40 \mathrm{pg} / \mathrm{uL}$

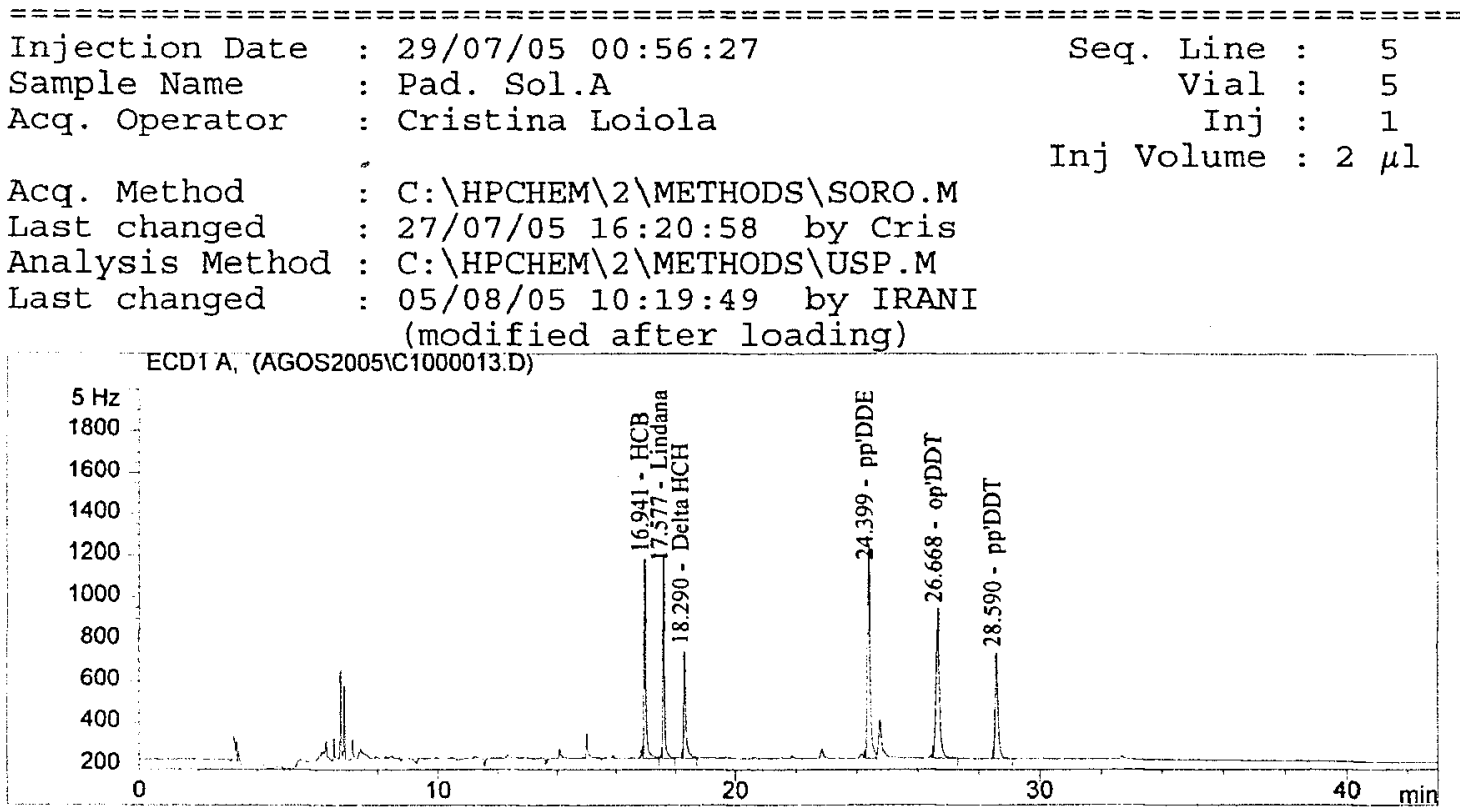

External Standard Report

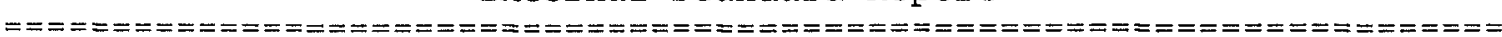

Sorted By

Calib. Data Modified :

Multiplier

Dilution

Signal 1: ECD1 A,

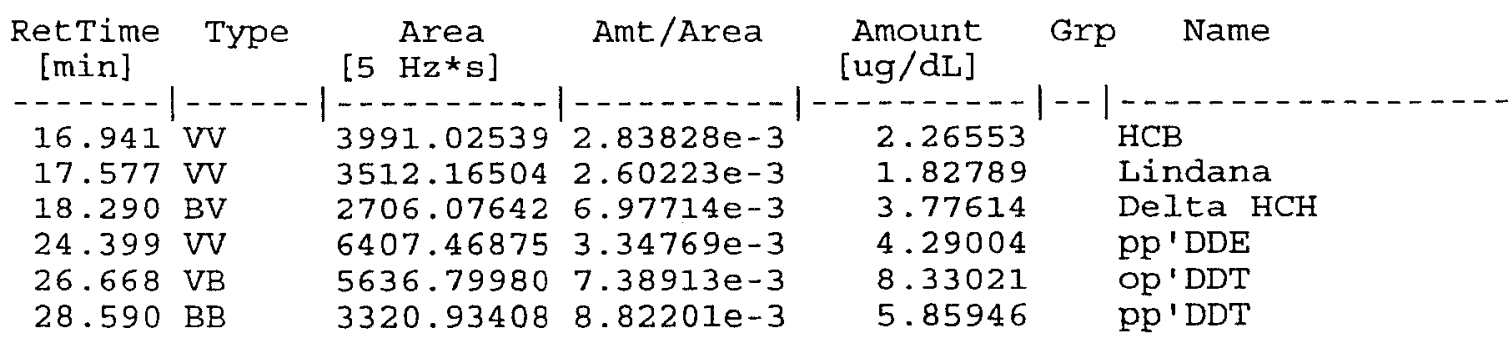

Totals :
Signal

Friday, 5 5e August 5e 2005 10:19:44

0.2000

1.0000

Results obtained with enhanced integrator!

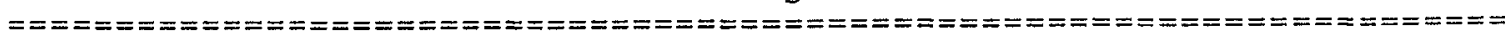

$\star \star \star$ End of Report $* \star \star$

Figura 12: Cromatograma da Curva 2- Solução " $A$ " Delta $\mathrm{HCH}+\mathrm{Gama} \mathrm{HCH}$ Concentração 10pg $\mu \mathrm{L}^{-1}$ Gama HCH Lindana e $20 \rho g \mathrm{LL}^{-1}$ Delta $\mathrm{HCH}$ 
$\mathrm{HCB}$, Lindana $=50 \mathrm{pg} / \mathrm{uL}$

Delta HCH, pP'DDE $=100 \mathrm{pg} / \mathrm{uL}$

$\mathrm{pp}^{\prime} \mathrm{DDT}, \mathrm{op} \mathrm{DDT}^{\prime}=200 \mathrm{pg} / \mathrm{uL}$

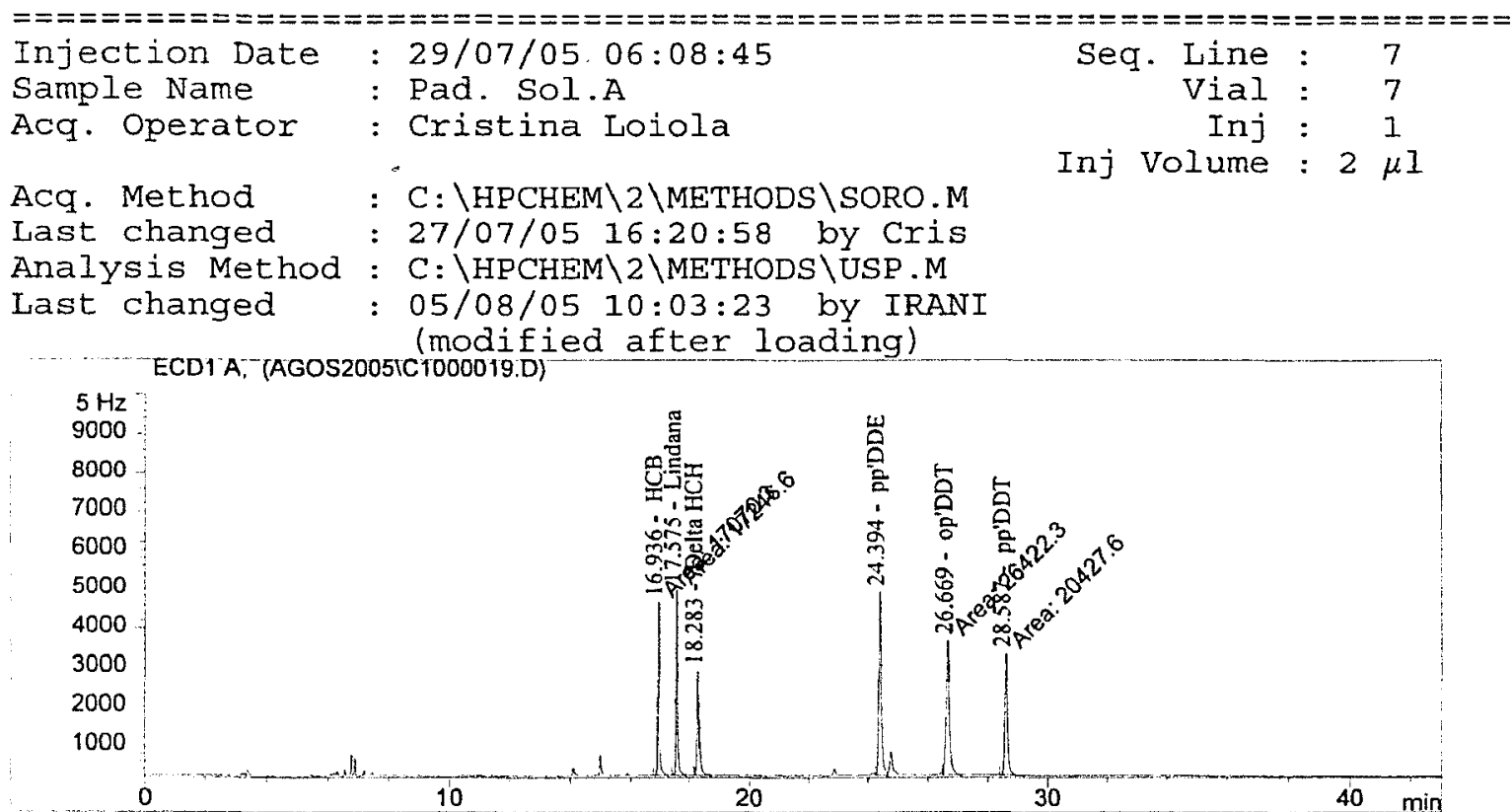

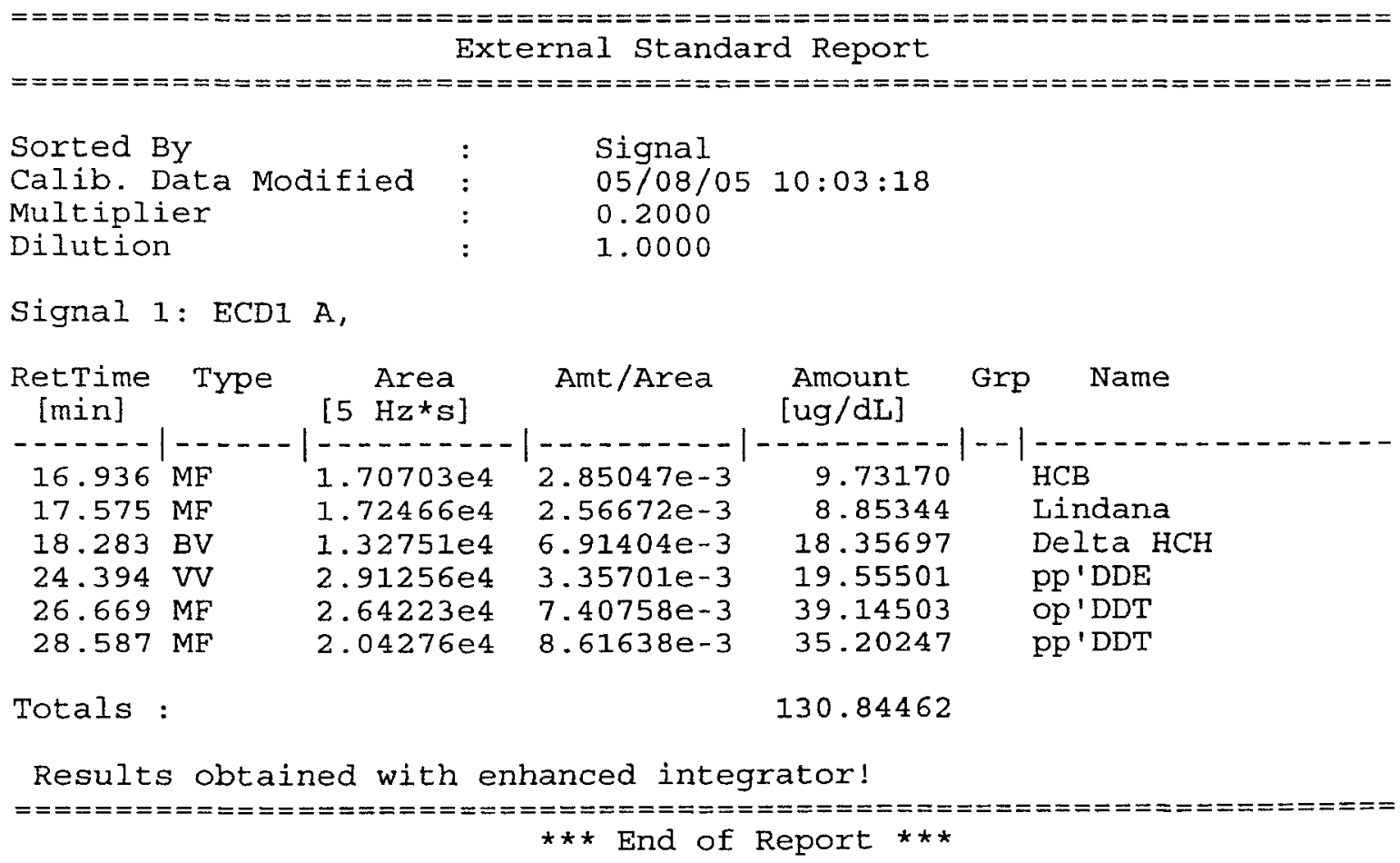

Figura 13: Cromatograma da Curva 2- Solução " $\mathrm{A}$ " Delta $\mathrm{HCH}+\mathrm{Gama} \mathrm{HCH}$ Concentração $50 \mathrm{pg} \mu^{-1}$ Gama HCH Lindana e $100 \rho g \mathrm{LL}^{-1}$ Delta $\mathrm{HCH}$ 
$\mathrm{HCB}$, Lindana $=100 \mathrm{pg} / \mathrm{uL}$

Delta HCH, pp'DDE $=200 \mathrm{pg} / \mathrm{uL}$

$\mathrm{pp}^{\prime} \mathrm{DDT}, \mathrm{op} \mathrm{PDT}^{\prime}=400 \mathrm{pg} / \mathrm{uL}$

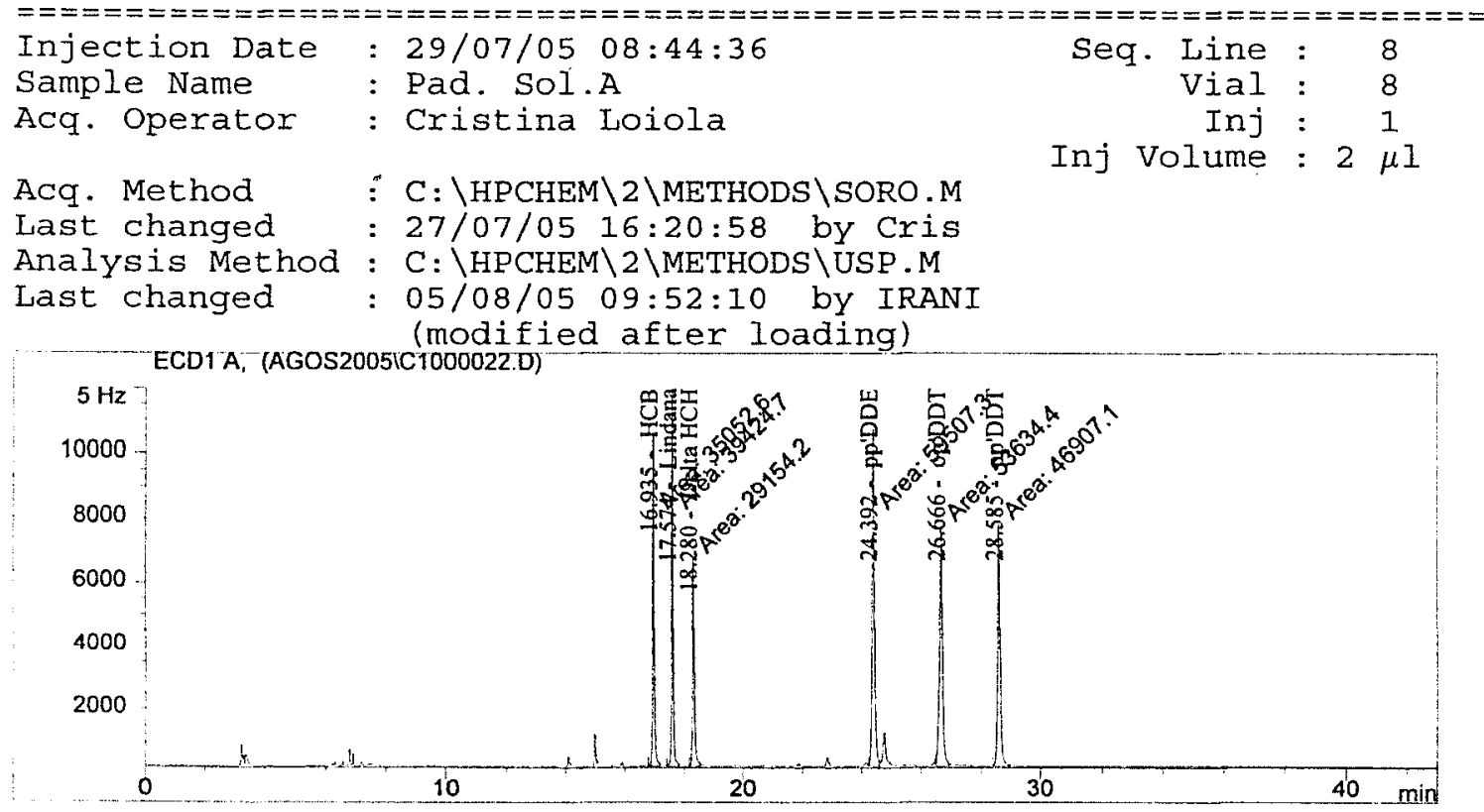

External Standard Report

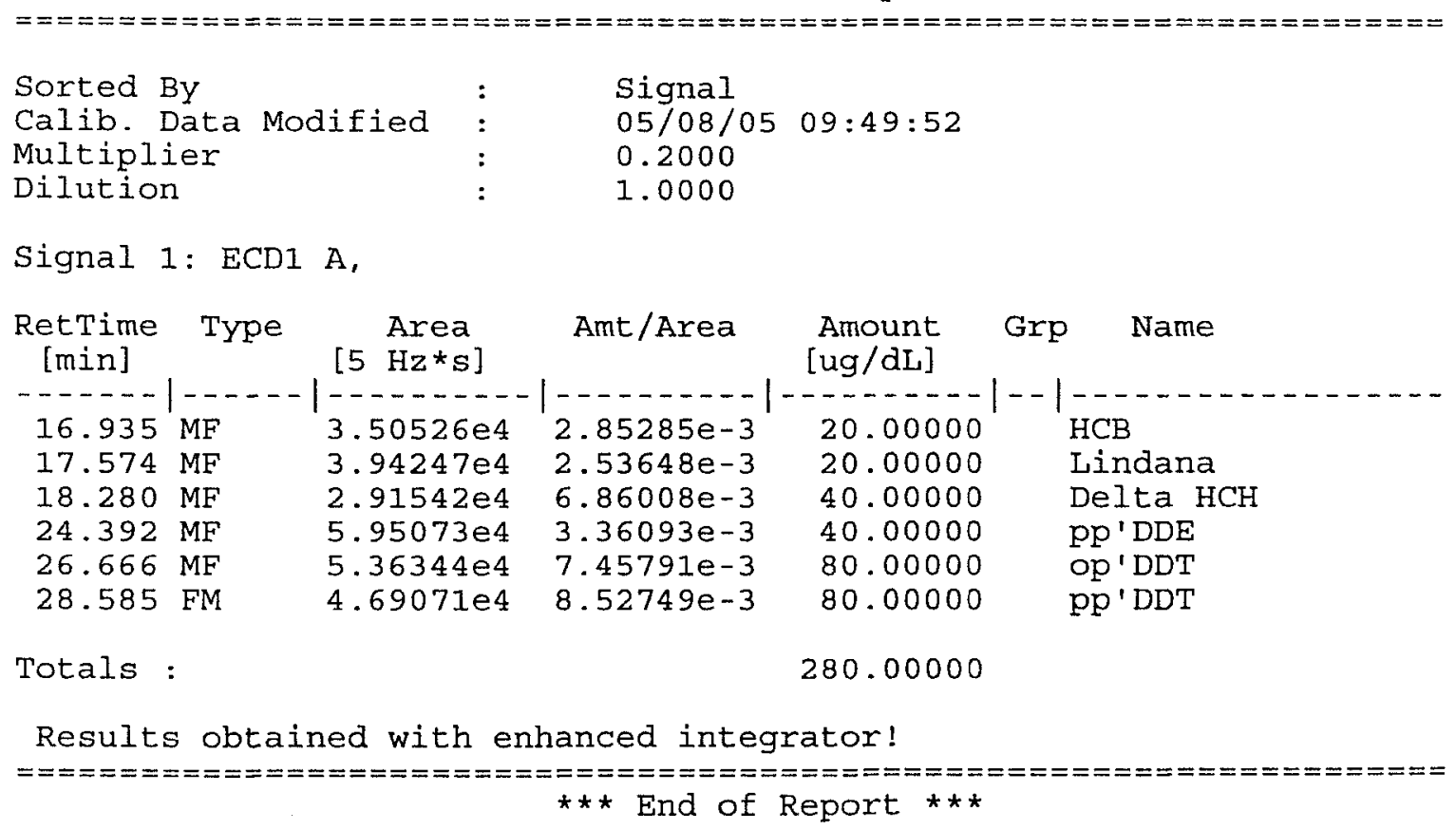

Figura 14: Cromatograma da Curva 2- Solução " $A$ " Delta $\mathrm{HCH}+\mathrm{Gama} \mathrm{HCH}$ Concentração 100pg $\mu \mathrm{L}^{-1} \mathrm{Gama} \mathrm{HCH}$ Lindana e $200 \rho g \mathrm{~L}^{-1}$ Delta $\mathrm{HCH}$ 


\subsection{Preparação das Amostras}

As amostras de soro sangüineo foram enviadas em tubos lacradas, congeladas e devidamente identificadas ao chegarem ao laboratório o material foi colocado em sacos de polietileno, contendo etiquetas devidamente preenchidas, que após retirada da amostra para análise foi acondicionados em estantes devidamente identificada dentro do freezer, temperatura de $-20^{\circ} \mathrm{C}$.

\subsection{Extração dos ativos na amostra}

a) Pipetar $1 \mathrm{~mL}$ da amostra de soro sangüíneo e transferir para um tubo de vidro de $15 \mathrm{~mL}$.

b) Para a recuperação fortificar a amostra branco neste momento.

c) Adicionar $5 \mathrm{~mL}$ de hexano.

d) Agitar por $1 \mathrm{~min}$ em agitador de tubos com velocidade de 5000 r.p.m seguido de 10 min em ultrasônica na potência máxima.

e) Transferir a fase orgânica para outro tubo de vidro com tampa esmerilhada graduado de $15 \mathrm{~mL}$.

f) Extrair novamente, adicionar mais $5 \mathrm{~mL}$ de hexano na amostra de soro sangüíneo.

g) Transferir a fase orgânica para o tubo que já contem $5 \mathrm{~mL}$ da primeira extração (item " $e$ ").

h) Concentrar em concentrador automático com fluxo de nitrogênio o extrato a fase orgânica - hexanica até $2 \mathrm{~mL}$.

i) Transferir os $2 \mathrm{~mL}$ (limpando as paredes do tubo de vidro de $15 \mathrm{~mL}$ ), para frasco de vidro do injetor automático.

h) Injetar 2,0 $4 \mathrm{~L}$ em GC-ECD utilizando os parâmetros nas condições de operação descritos no item 4.9 .

Na figura 15 é apresentado o fluxograma utilizado para análise de resíduos de $\mathrm{HCH}$. 
$1 \mathrm{~mL}$ de Amostra

Add $5 \mathrm{~mL}$ de Hexano

Agitar por $1 \mathrm{~min}$ em agitador de tubos 5000 r.p.m.

10 min em Ultrasônica

Transferir a fase orgânica Para tubo graduado de $15 \mathrm{~mL}$

Repetir a extração com $5 \mathrm{~mL}$ de hexano

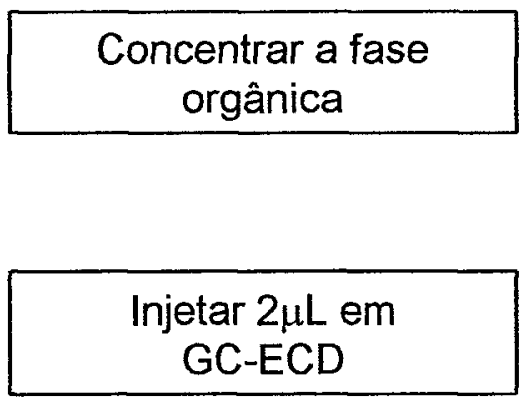

Figura 15: Fluxograma para analise de resíduos de $\mathrm{HCH}$ e seus isômeros em soro sangüíneo 


\subsection{Fortificação do ativo na amostra}

Com finalidade de validação e acompanhamento do ensaio, foi fortifica em quintuplicata as amostras branco com o padrão analítico dos ativos estudados, em dois níveis de concentração: $0,04 \mu \mathrm{g} \mathrm{dL}^{-1}$ e $0,40 \mu \mathrm{g} \mathrm{dL}^{-1}$ para ALFA HCH e LINDANA e 0,08 $\mu \mathrm{g} \mathrm{dL}^{-1}$ e $0,80 \mu \mathrm{g} \mathrm{dl}_{-}^{-1}$ para BETA e DELTA de acordo com:

a) Nivel de $0,04 \mu \mathrm{g} \mathrm{dL}^{-1}$ para ALFA e LINDANA e $0,08 \mu \mathrm{g} \mathrm{\textrm {dL } ^ { - 1 }}$ para BETA e DELTA

Adicionar $40 \mu \mathrm{L}$ e $80 \mu \mathrm{L}$ das respectivas soluções SI-A em 1,0mL da amostra branco em tubo de $15 \mathrm{~mL}$ para obtenção da concentração final de $0,04 \mu \mathrm{g} \mathrm{dL}^{-1} \mathrm{e}$ $0,08 \mu \mathrm{g} \mathrm{dL}^{-1}$. Proceder conforme método de extração.

b) Nivel de $0,4 \mu \mathrm{g} \mathrm{dL}{ }^{-1}$ para ALFA e LINDANA e $0,8 \mu \mathrm{g} \mathrm{dL}^{-1}$ para BETA e DELTA

Adicionar $400 \mu \mathrm{L}$ e $800 \mu \mathrm{L}$ das respectivas soluções SI-A em 1,0mL da amostra branco em tubo de $15 \mathrm{~mL}$ para obtenção da concentração final de $0,4 \mu \mathrm{g} \mathrm{dL}^{-1}$ e 0,8 $\mu \mathrm{g} \mathrm{dL} \mathrm{L}^{-1}$. Proceder conforme método de extração.

Nas figuras 16 a 19 são apresentadas os cromatogramas obtidos no estudo de recuperação do $\mathrm{HCH}$. 
Alfa $\mathrm{HCH}=0,04 \mathrm{ug} / \mathrm{dL}$

Beta HCH, Aldrin, Dieldrin $=0,08 \mathrm{ug} / \mathrm{dL}$,

Endrin, op'DDE $=0,12 \mathrm{ug} / \mathrm{dL}$
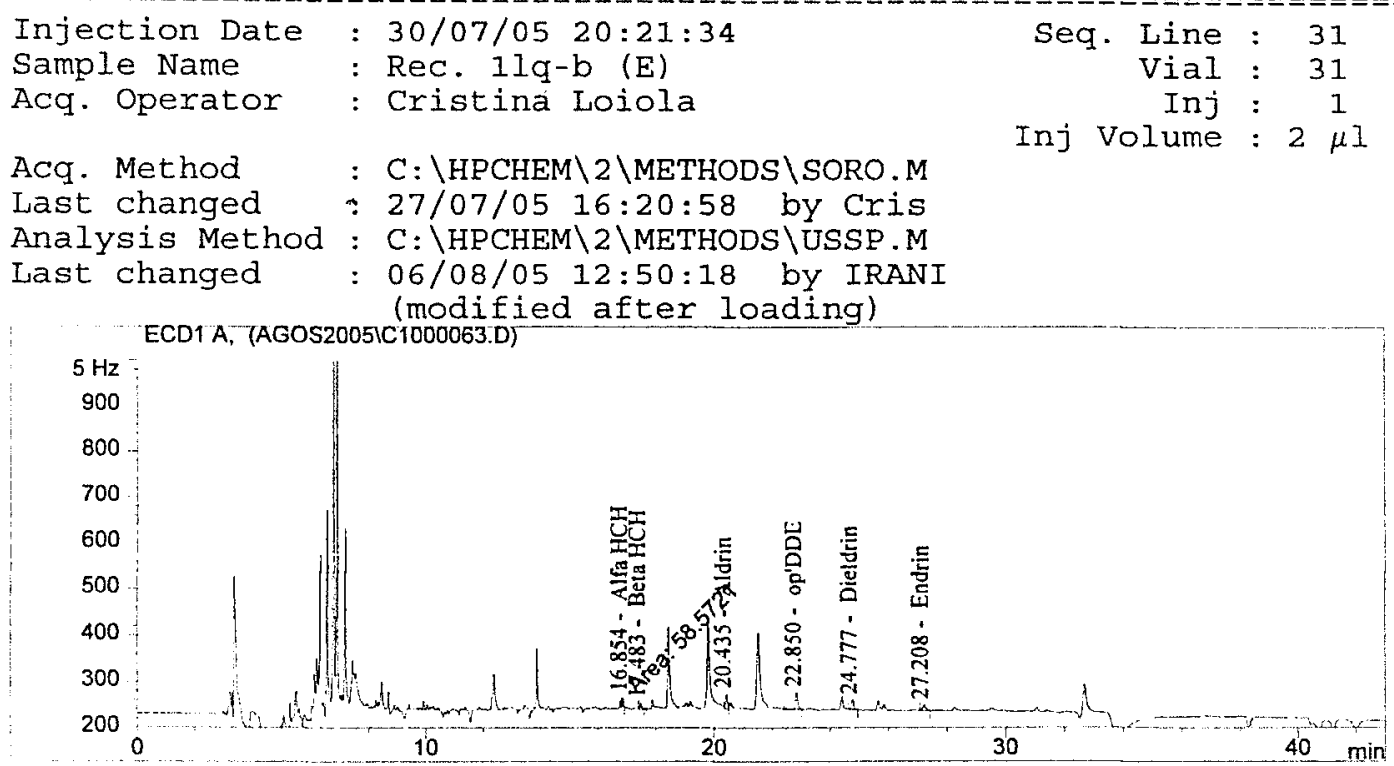

External Standard Report

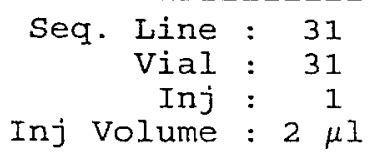

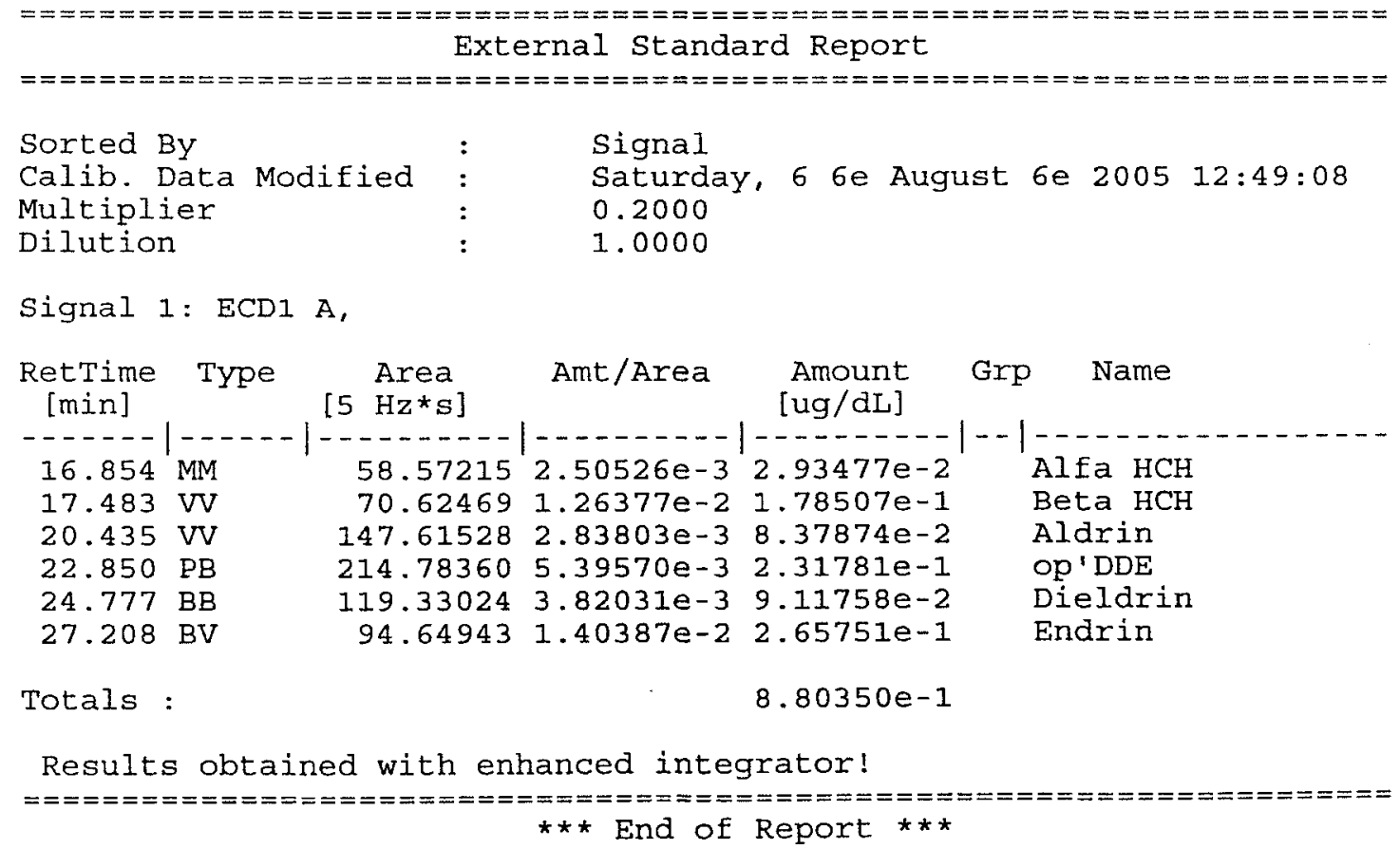

Figura 16: Cromatograma da Recuperação Alfa $\mathrm{HCH}+$ Beta $\mathrm{HCH}$ - 1LOQ 
Alfa $\mathrm{HCH}=0,4 \mathrm{ug} / \mathrm{dL}$

Beta $\mathrm{HCH}, \mathrm{Aldrin}$, Dieldrin $=0,8 \mathrm{ug} / \mathrm{dL}$

Endrin, op'DDE $=1,2 \mathrm{ug} / \mathrm{dL}$
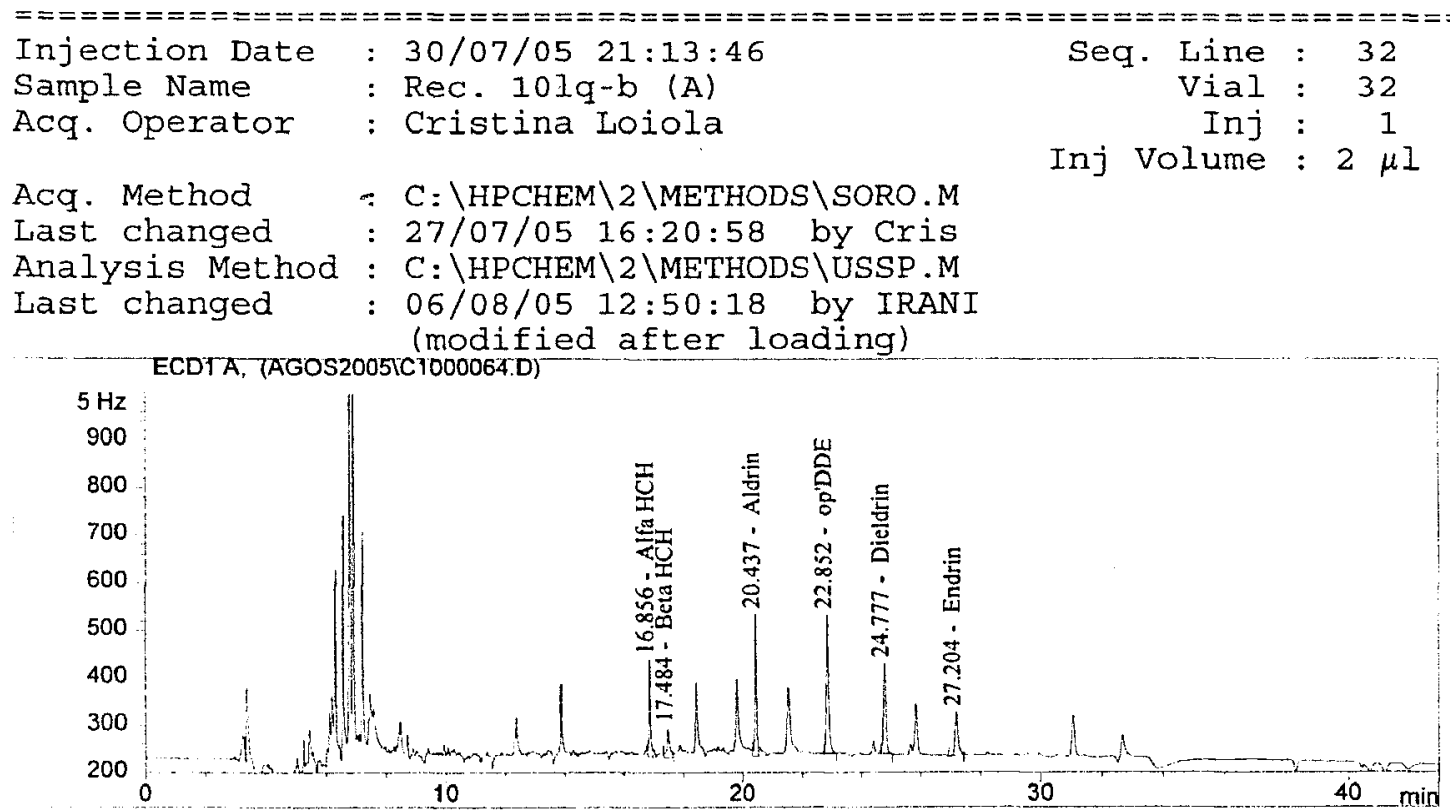

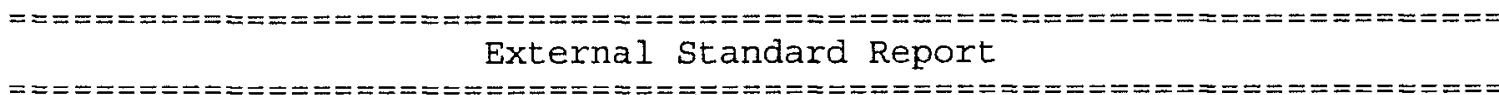

Sorted By

Calib. Data Modified

Multiplier

Dilution
Signal

Saturday, 6 6e August 6e 2005 12:49:08

0.2000

1.0000

Signal 1: ECD1 A,

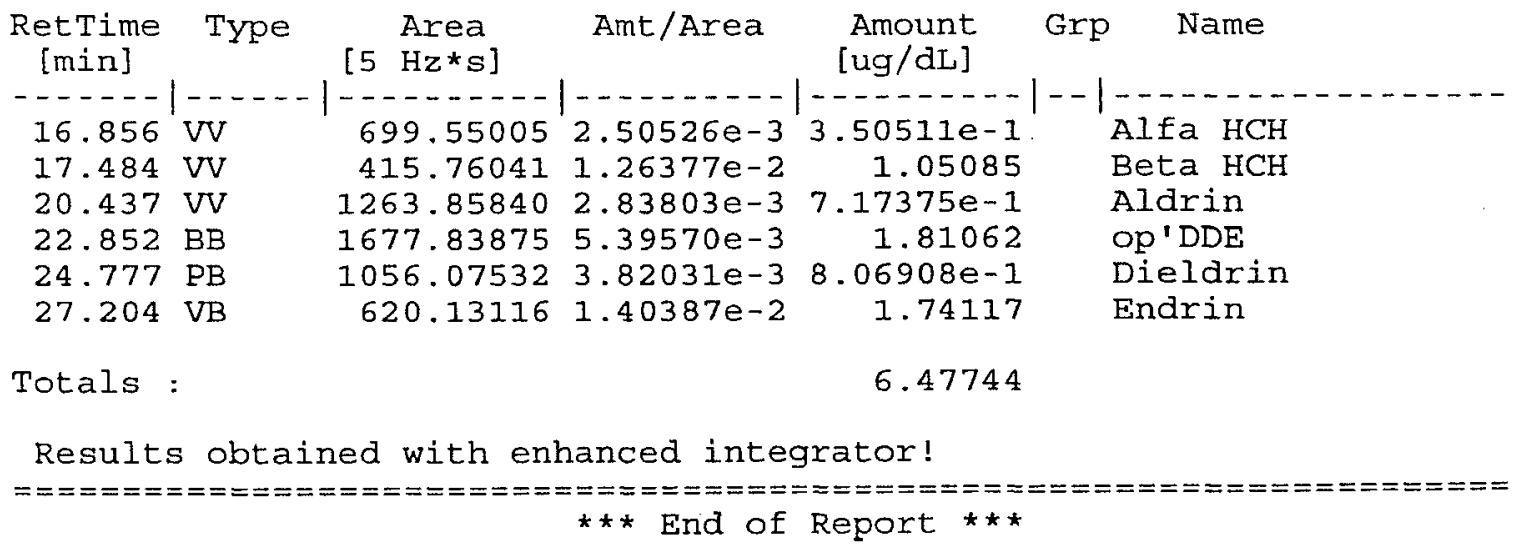

Figura 17: Cromatograma da Recuperação Alfa HCH + Beta HCH - 10LOQ 
$\mathrm{HCB}$, Lindana $=0,04 \mathrm{ug} / \mathrm{dL}$

Delta HCH, pp'DDE $=0,08 \mathrm{ug} / \mathrm{dL}$

$\mathrm{pp}^{\prime} \mathrm{DDT}, \mathrm{op} \mathrm{pDT}^{\prime}=0,12 \mathrm{ug} / \mathrm{dL}$
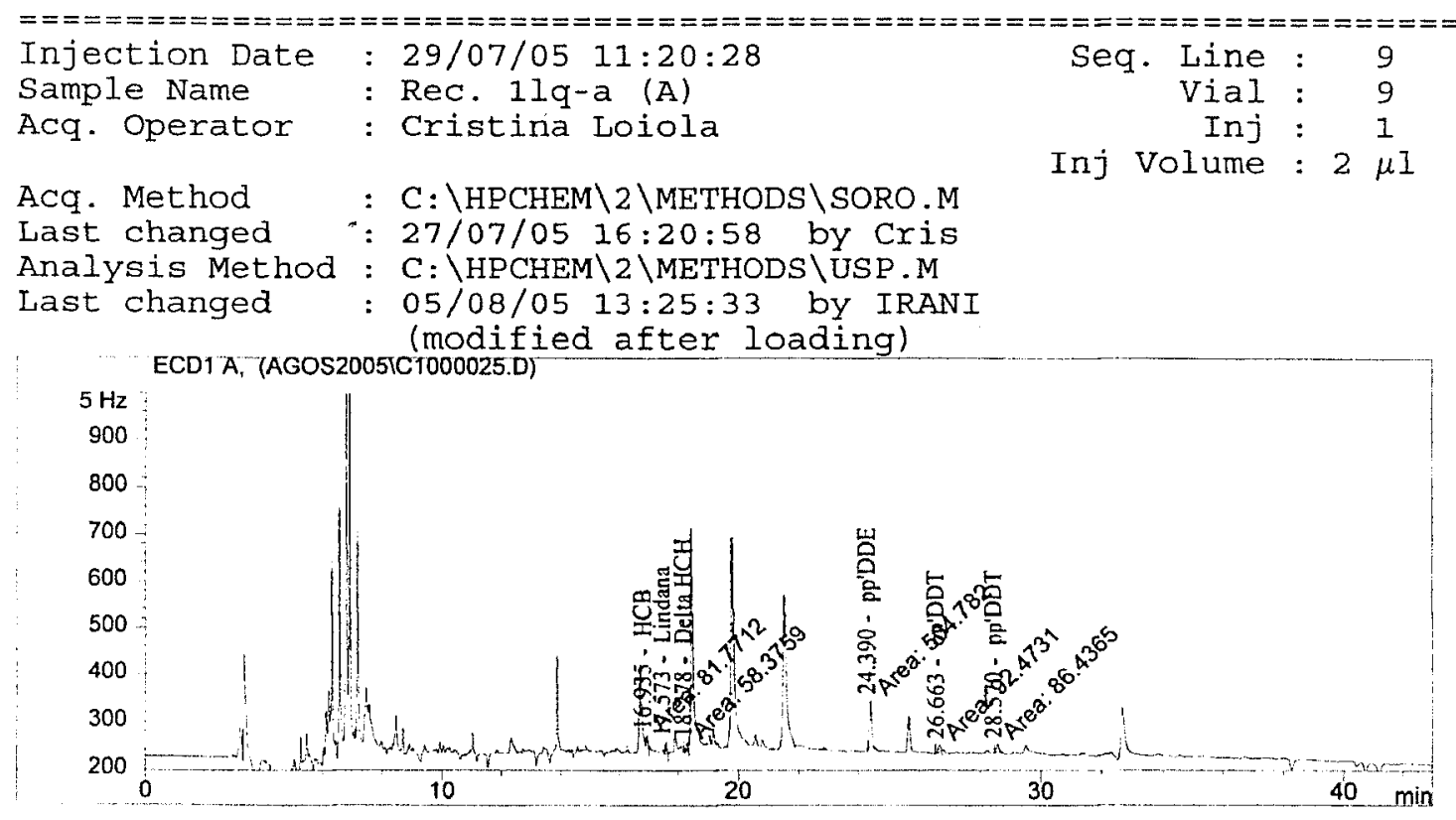

\section{External standard Report}

Sorted By

Calib. Data Modified

Multiplier

Dilution

\section{Signal}

Friday, 5 5e August 5e 2005 12:10:40

0.2000

1.0000

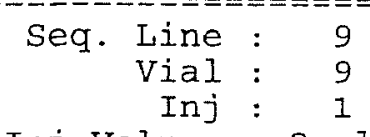

Inj Volume : $2 \mu I$

Signal 1: ECD1 A,

\begin{tabular}{|c|c|c|c|c|c|}
\hline $\begin{array}{l}\text { RetTime } \\
\text { [min] }\end{array}$ & Type & {$\left[\begin{array}{ll} & \text { Area } \\
{[5} & \mathrm{Hz}^{\star} \mathrm{S}\end{array}\right]$} & Amt/Area & $\begin{array}{l}\text { Amount } \\
\text { [ug/dL] }\end{array}$ & Grp Name \\
\hline & & & & - - - - - & 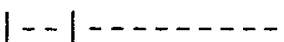 \\
\hline 16.935 & MM & 81.77119 & $2.83782 e-3$ & $4.64104 e-2$ & HCB \\
\hline 17.573 & VV & 81.29852 & $2.60221 e-3$ & $4.23112 e-2$ & Lindana \\
\hline 18.278 & MM & 58.37590 & $6.97707 e-3$ & $8.14585 e-2$ & Delta $\mathrm{HCH}$ \\
\hline 24.390 & MM & 504.78226 & $3.34735 e-3$ & $3.37936 e-1$ & Pp'DDE \\
\hline 26.663 & MM & 92.47312 & $7.38861 e-3$ & $1.36650 \mathrm{e}-1$ & OP'DDT \\
\hline 28.570 & MM & 86.43648 & $8.82289 e-3$ & $1.52524 e-1$ & pp'DDT \\
\hline
\end{tabular}

Totals :

$$
7.97290 e^{-1}
$$

Results obtained with enhanced integrator!

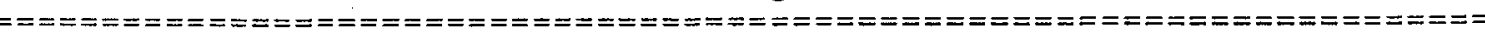

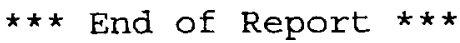

Figura 18: Cromatograma da Recuperação Gama HCH + Delta HCH - 1LOQ 
HCB, Lindana $=0,4 \mathrm{ug} / \mathrm{dL}$

Delta $\mathrm{HCH}, \mathrm{pp}{ }^{\mathrm{DDE}}=0,8 \mathrm{ug} / \mathrm{dL}$

$\mathrm{pp}^{\prime} \mathrm{DDT}, \mathrm{op} \cdot \mathrm{DDT}=1,2 \mathrm{ug} / \mathrm{dL}$

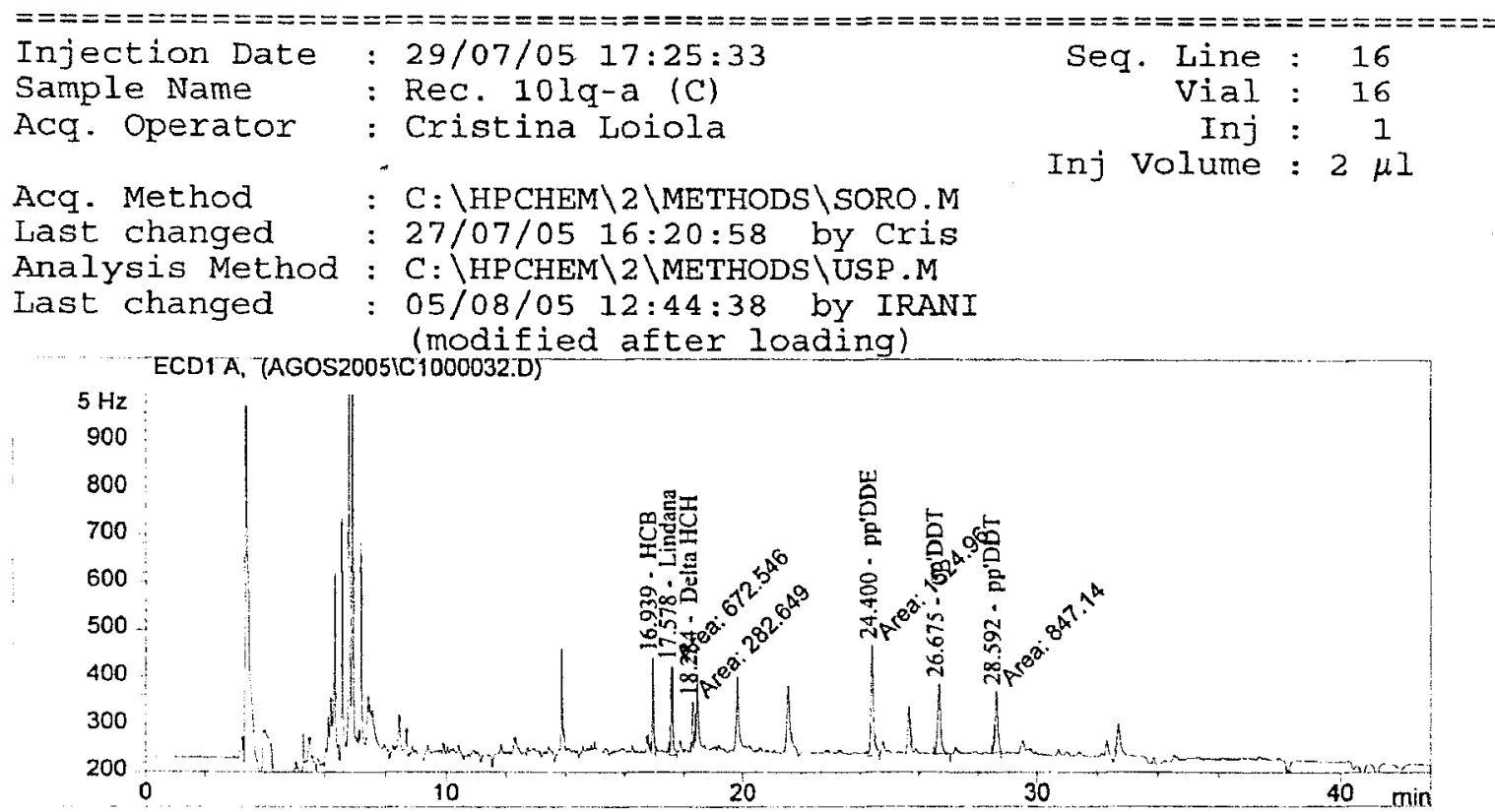

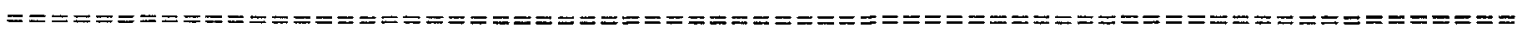
External Standard Report

Sorted By

Calib. Data Modified

Multiplier

Dilution

Signal 1: $\operatorname{ECD} 1 \mathrm{~A}$,

Signal

Friday, 5 5e August 5e 2005 12:10:40

0.2000

1.0000

\begin{tabular}{|c|c|c|c|c|c|c|}
\hline $\begin{array}{c}\text { RetTime } \\
\text { [min] }\end{array}$ & Type & {$\left[\begin{array}{ll}\text { Area } \\
{\left[5 \mathrm{~Hz}^{\star} \mathrm{S}\right.}\end{array}\right]$} & Amt / Area & $\begin{array}{l}\text { Amount } \\
\text { [ug/dL] }\end{array}$ & Name & \\
\hline----- & & $\ldots . . .$. & $1--$ & | $-\ldots$ & |-- & \\
\hline 16.939 & vV & 722.42999 & $2.83782 e-3$ & $4.10026 \mathrm{e}-1$ & $\mathrm{HCB}$ & \\
\hline 17.578 & MM & 672.54633 & $2.60221 e-3$ & $3.50021 e-1$ & Lindana & \\
\hline 18.284 & MM & 282.64880 & $6.97707 e-3$ & $3.94412 e-1$ & Delta $\mathrm{HCH}$ & \\
\hline 24.400 & MM & 1524.96057 & $3.34735 e-3$ & 1.02091 & $\mathrm{PP} D D E$ & \\
\hline 26.675 & VB & 1104.25720 & $7.38861 e-3$ & 1.63179 & Op'DDT & \\
\hline 28.592 & $M M$ & 847.14032 & $8.82289 e-3$ & 1.49484 & pp'DDT & \\
\hline rotals & : & & & 5.30200 & & \\
\hline
\end{tabular}

Results obtained with enhanced integrator!

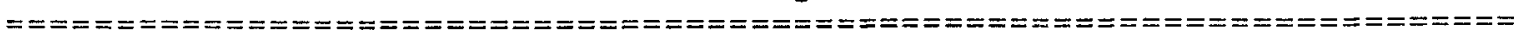
$\star \star \star$ End of Report $\star \star \star$
}

Figura 19: Cromatograma da Recuperação Gama HCH + Delta HCH - 10LOQ 


\subsection{Análise Instrumental}

As seguintes condições foram usadas com sucesso durante 0 desenvolvimento deste método analítico

\begin{tabular}{|c|c|}
\hline Instrumento & Cromatógrafo á Gás \\
\hline Detecção & Captura de Elétrons \\
\hline Coluna & HP-5 \\
\hline Gás de Arraste & Nitrogênio ultra puro \\
\hline Fluxo de gás de Arraste & $0,900 \mathrm{~mL} / \mathrm{min}$ \\
\hline Modo de injeção & "splintless" \\
\hline Rampa & $\begin{array}{l}1 \mathrm{~min}\left(60^{\circ} \mathrm{C}\right)-10^{\circ} \mathrm{C} / \mathrm{min}\left(200^{\circ}\right) 10 \mathrm{~min}-20^{\circ} \mathrm{C} / \mathrm{min}- \\
5 \mathrm{~min} .\end{array}$ \\
\hline Volume injetado & $2 \mu \mathrm{L}$ \\
\hline Tempo Total de Corrida & Aproximadamente 40 minutos \\
\hline $\begin{array}{l}\text { Tempo de Retenção } \\
\text { Alfa }\end{array}$ & Aproximadamente 16,8 minutos \\
\hline $\begin{array}{l}\text { Tempo de Retenção } \\
\text { Beta }\end{array}$ & Aproximadamente 17,4 minutos \\
\hline $\begin{array}{l}\text { Tempo de Retenção } \\
\text { Delta }\end{array}$ & Aproximadamente 18,2 minutos \\
\hline $\begin{array}{l}\text { Tempo de Retenção } \\
\text { Gama "Lindana" }\end{array}$ & Aproximadamente 17,5 minutos \\
\hline Nome do Método & SORO.M \\
\hline
\end{tabular}

\subsection{Validação das adaptações ao método}

O uso de uma determinada metodologia analítica deve ser sempre precedido da verificação de sua aplicabilidade ao propósito específico. A avaliação da metodologia proposta permite verificar essa aplicabilidade. A utilização de métodos validados em um, ou mais laboratórios, diferentes daquele que realizará as análises, deve ser precedida por uma avaliação da conformidade ou validação desse método.

Condições que determinam a validade de um método variam em função das 
condiçōes operacionais do laboratório, bem como, das práticas utilizadas pelos profissionais envolvidos. Mudanças substanciais nas condições em que as análises são feitas (materiais ou humanas) deveriam determinar a necessidade de uma revalidação do método.

A validação da metodologia de análise de resíduos de agrotóxicos, tem como fundamento verificar a adequação dos procedimentos propostos ou estabelecidos para a combinação especifica ingrediente ativo-matriz, dentro de determinados parâmetros operacionais do laboratório executante. Durante 0 processo de validação, os parâmetros do método são estabelecidos. Por parâmetros do método entende-se: exatidão, precisão, limite de deteç̧ão (LOD), limite de quantificação (LOQ), especificidade, linearidade, faixa e robustez.

Neste contexto, ND (nada detectado) significa qualquer nível de resíduos abaixo do limite de detecção. O limite inferior de validação é o limite de quantificação (LOQ), e o limite superior de validação é o maior no qual se conduziram recuperações dentro dos padrões de conformidade.

\subsection{Critérios de ensaios de conformidade}

\subsubsection{Curva de calibração (Linearidade)}

Injetar no equipamento, no mínimo 5 soluções-padrão de diferentes concentrações, para se obter a curva de linearidade. A ordem de injeção das soluções-padrão deve ser crescente e deve ser injetado no mínimo 3 vezes. Plotar as áreas dos picos do padrão, contra as suas conhecidas concentrações, para a construção da curva de linearidade. Uma curva de regressão aceitável deve apresentar um coeficiente de correlação $\left(R^{2}\right)$ maior ou igual a 0,99 . A soluçãopadrão de menor concentração da curva de calibração deve ser maior ou igual a metade do limite de quantificação. A solução-padrão de maior concentração da curva de calibração deve ser 10 vezes maior que a concentração da amostra no limite de quantificação. 


\subsubsection{Especificidade/Seletividade}

Os métodos devem ser capazes de determinar os analitos na presença da matriz. Teste realizado com a amostra branco não deve apresentar interferentes na região cromatográfica, mas se estes aparecerem os valores quando comparados com padrões do analito que se está estudando devem ser menor ou igual a $30 \%$ do LOQ.

\subsubsection{Precisão de Medição}

A precisão é determinada com base nos experimentos de recuperação em cada nivel estudado.

\subsubsection{Exatidão/Recuperação}

A exatidão é determinada com base nos experimentos de recuperação em todos os níveis estudados. O nível superior de fortificação deve ser maior ou igual ao maior resíduo nas amostras tratadas do estudo. Conduzir, no mínimo, 5 (cinco) recuperações neste nível. O intervalo de aceitabilidade para os valores individuais de recuperação é de $70-120 \%$.

\subsubsection{Limite de Deteç̧ão (LOD)/Limite de Quantificação (LOQ)}

O LOD é determinado nas condições específicas da amostra em estudo. Calcular-se o LOD estatístico como 3 vezes o desvio-padrão das concentrações recuperadas no cálculo do $L O Q$ estatístico. Se o $L O D$ do equipamento for maior que o LOD estatístico prevalecerá o valor maior. A menor quantidade detectada pode ser no mínimo $1 / 2$ LOQ. O LOQ proposto é confirmado através de experimentos de recuperação na matriz de interesse. Conduzir 5 recuperações no LOQ proposto e calcular a quantidade recuperada em cada determinação em micrograma por 
decilitros $\left(\mu \mathrm{g} \mathrm{dL}^{-1}\right)$, a média $(\bar{x})$ e o desvio-padrão (DP) das quantidades recuperadas. Calcular o LOQ estatístico, definido como 10 vezes o valor do desvio padrão "DESVPAD" das concentrações recuperados no 1LOQ. O LOQ proposto é considerado aceitável quando for maior ou igual ao $L O Q$ estatístico. Caso a condição acima não seja atingida, conduzir mais recuperações, recalcular o desviopadrão e reaplicar o critério. Alterar o método ou o LOQ proposto, se pela segunda vez o critério não for atingido. As regras gerais estão descritas nas tabelas 4 e 5 .

Tabela 4: Limite de Detecção (LOD)

\begin{tabular}{cc}
\hline Se & Então \\
\hline LOD estatístico $>$ LOD instrumental & LODmétodo = LODestatístico \\
LOD estatístico $<$ LOD instrumental & LODmétodo = LODinstrumental \\
\hline
\end{tabular}

Tabela 5: Limite de Quantificação(LOQ)

$\mathrm{Se}$ Então

LOQ estatistico $<$ LOQ proposto

Método Qualificado

\subsubsection{Repetibilidade}

O coeficiente de variação porcentual (CV\%) em relação à média de concentração para cada nível de fortificação estudado deve ser menor ou igual a $15 \%$.

\subsubsection{Incerteza de medição}

Para o propósito de determinação da incerteza de medição de um determinado método analítico, utiliza-se os conceitos de exatidão e precisão descrito acima.

No caso de análise de resíduos, a certeza associada aos instrumentos (metrológica), é muito menor que aquela associada ao processo analítico por ser, de forma que, a estimativa da incerteza de medição, é mais bem descrita pela incerteza no processo. 
A expressão da incerteza de medição é dada pelo intervalo de confiança da média das recuperações. 


\section{RESULTADOS E DISCUSSÕES}

\subsection{Dados da Validação}

Para a validação deste método no limite de quantificação proposto os ensaios de conformidade conduzidos de acordo com os critérios descritos no item anterior resultaram nos dados abaixo:

\subsubsection{Curva de calibração (Linearidade)}

A curva de calibração foi preparada através de três injeções cromatográficas para cada concentração das soluções-padrão Curva 1- Solução (B) "a" ao " $h$ " - 8 pontos e Curva 2- Solução (A) "i" ao "p" - 8 pontos.

Após cálculo das áreas dos picos obtidos, uma curva foi traçada correlacionando área versus concentração e a análise de regressão foi usada para determinar a equação da curva.

Tabela 6: Faixa de trabalho, equação da curva e coeficiente de correlação.

\begin{tabular}{cccc}
$\mathrm{HCH}$ & $\begin{array}{c}\text { Faixa } \\
\rho g \mu \mathrm{L}^{-1}\end{array}$ & Equação da Curva & $\begin{array}{c}\text { Coeficiente de correlação } \\
\left(\mathrm{R}^{2}\right)\end{array}$ \\
\hline$\alpha$ & $0,1-100$ & $\mathrm{Y}=389,89 \mathrm{X}+64,54$ & 0,9995 \\
\hline$\beta$ & $0,1-100$ & $\mathrm{Y}=90,947 \mathrm{X}+48,73$ & 0,9996 \\
\hline$\sigma$ & $0,2-200$ & $\mathrm{Y}=145,72 \mathrm{X}-35,53$ & 0,9999 \\
\hline$\gamma$ & $0,2-200$ & $\mathrm{Y}=393,63 \mathrm{X}-93,53$ & 0,9998
\end{tabular}

Uma representação gráfica da curva de calibração é mostrada nas figuras 20,21, 22 e 23. 
Figura 20: Curva de Calibração/ Linearidade Alfa HCH.

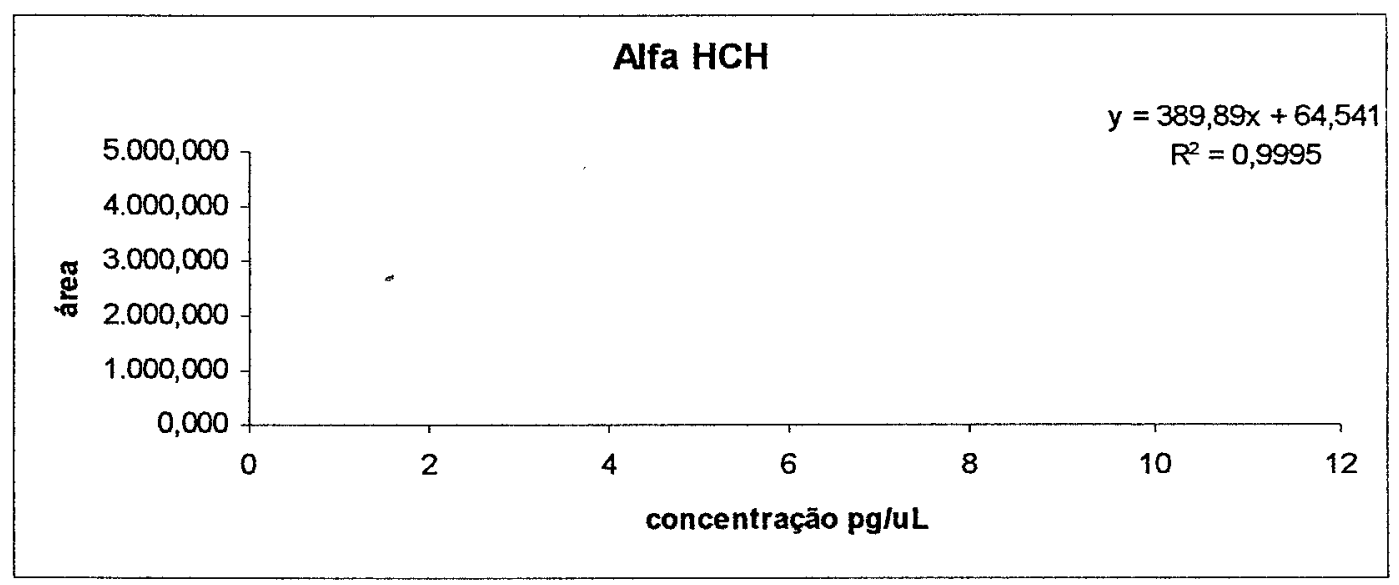

Figura 21: Curva de Calibração/ Linearidade Beta HCH.

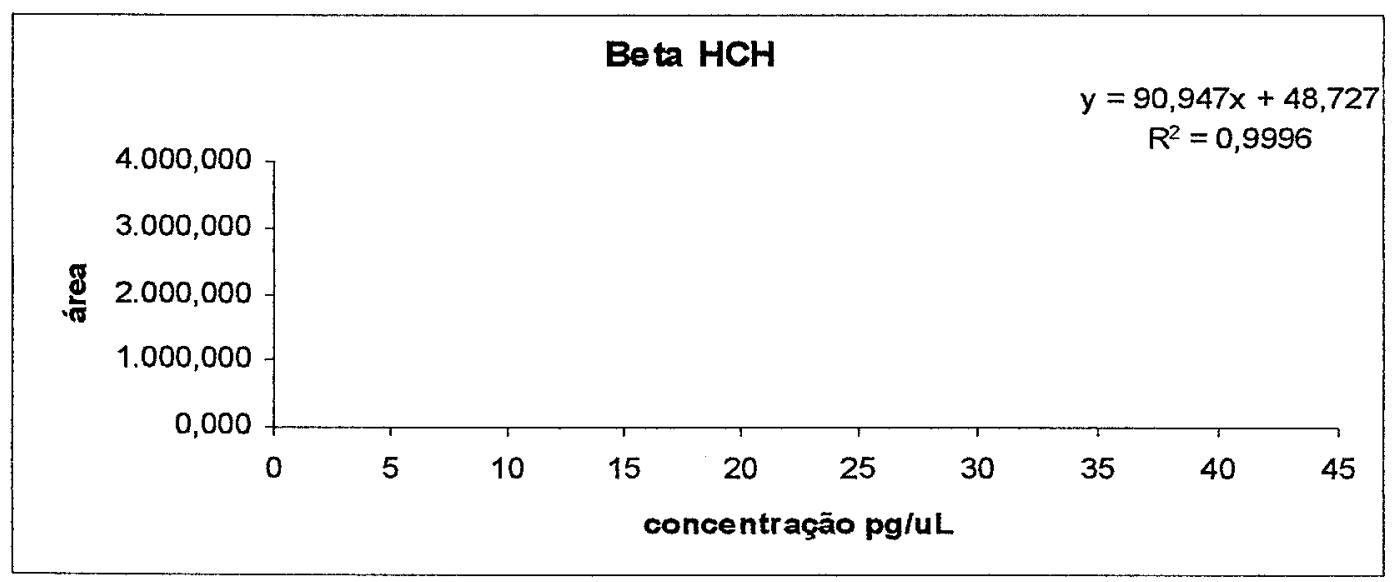

Figura 22: Curva de Calibração/ Linearidade Delta HCH.

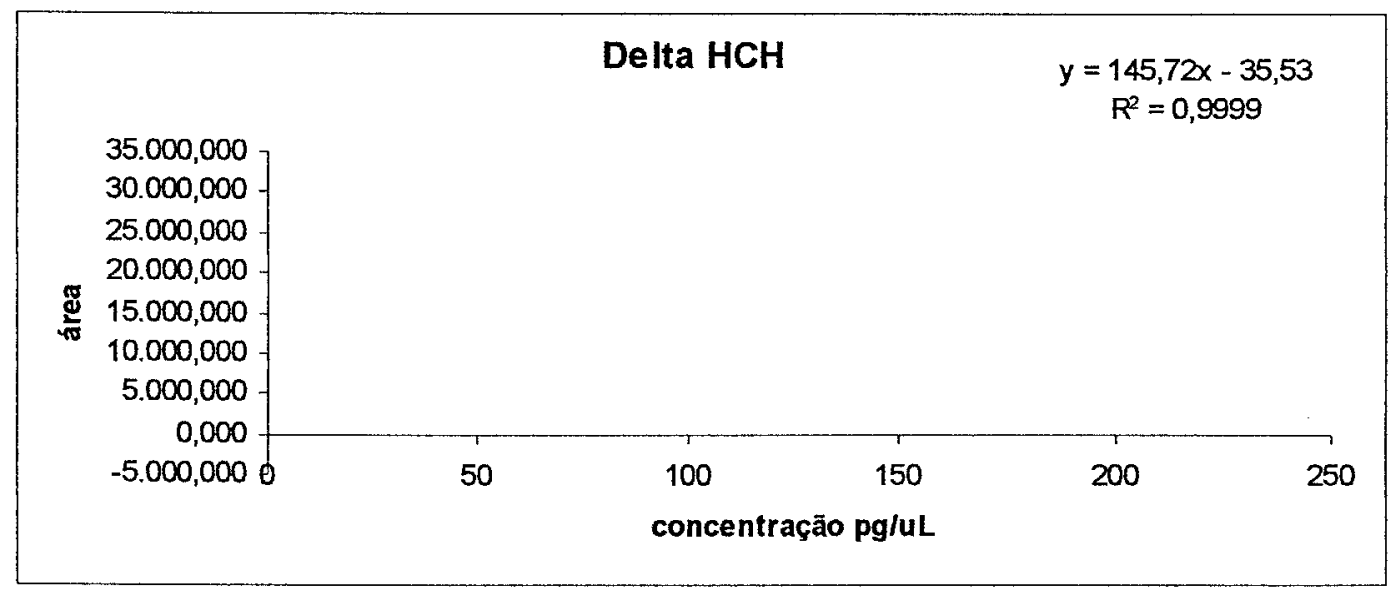


Figura 23: Curva de Calibração/ Linearidade Gama HCH - Lindana.

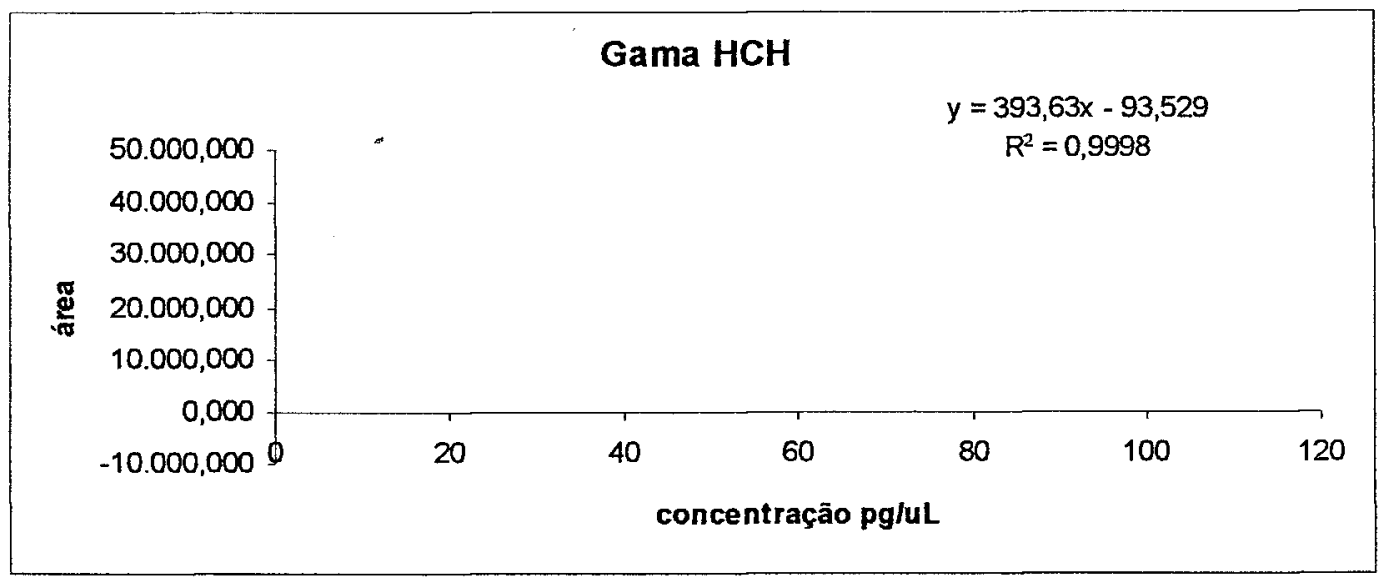

Seguem os cromatogramas da curva de calibração uma injeção de cada ponto. Alfa e Beta

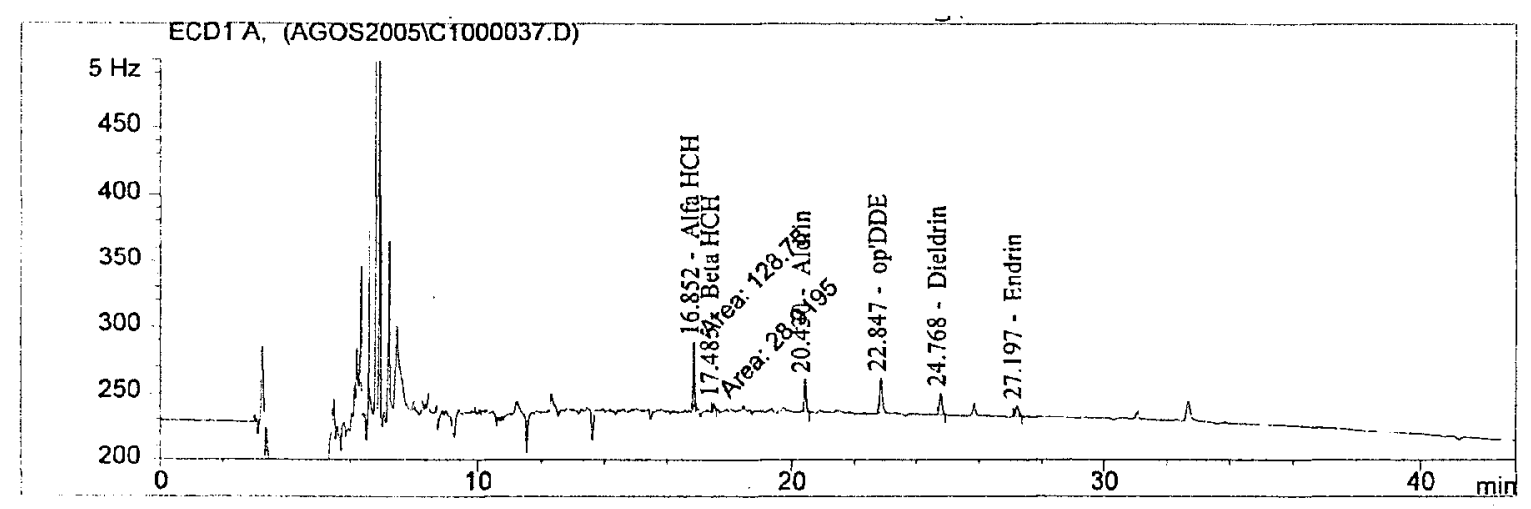

Figura 24: Cromatograma Alfa $0,1 \rho g \mathrm{~L}^{-1}$ e Beta $0,2 \rho g \mu \mathrm{L}^{-1}$.

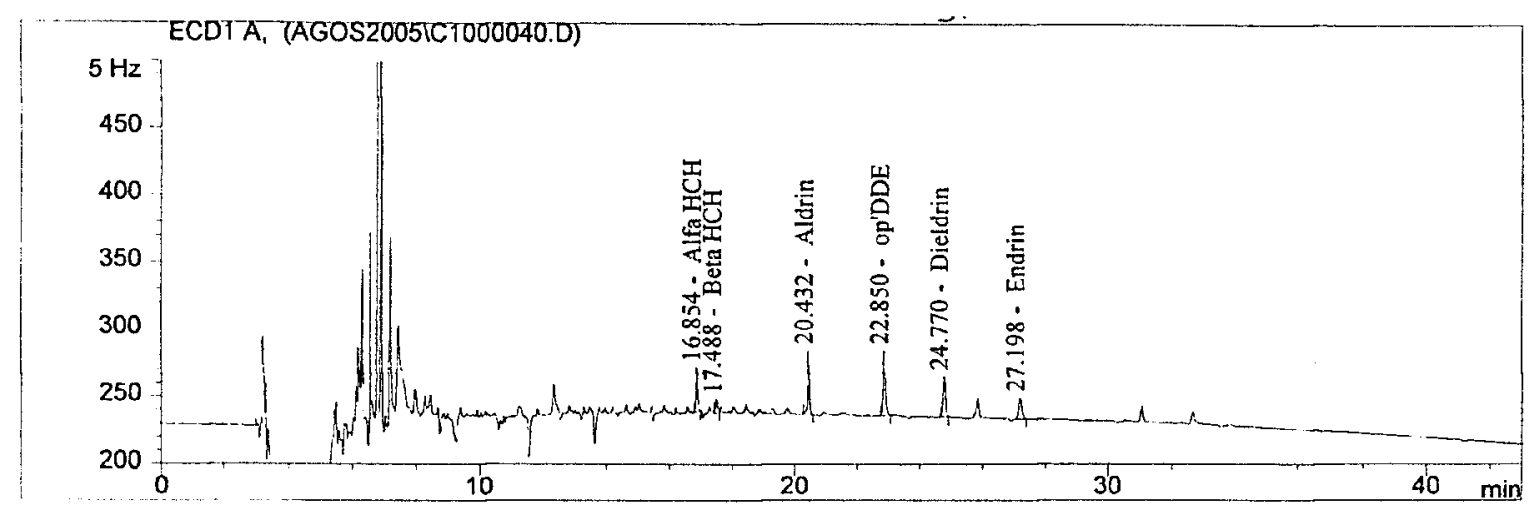

Figura 25: Cromatograma Alfa $0,2 p g \mu \mathrm{L}^{-1}$ e Beta $0,4 \rho g \mu \mathrm{L}^{-1}$. 


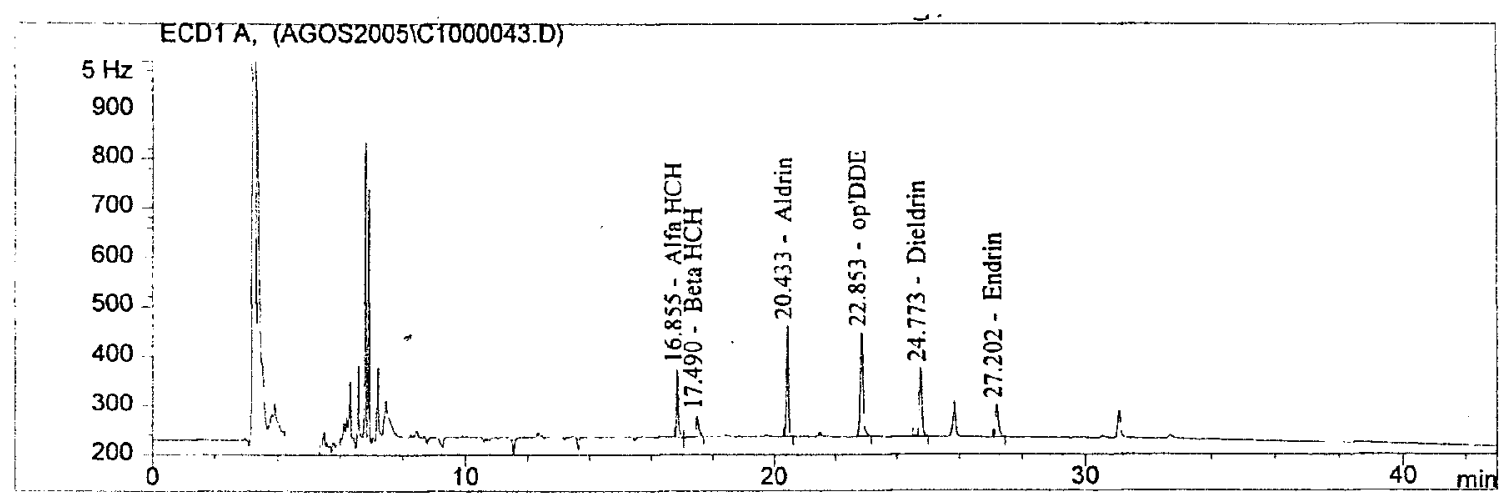

Figura 26: Cromatograma Alfa $1,0 \rho g \mu \mathrm{L}^{-1}$ e Beta 2,0pg $\mu \mathrm{L}^{-1}$.

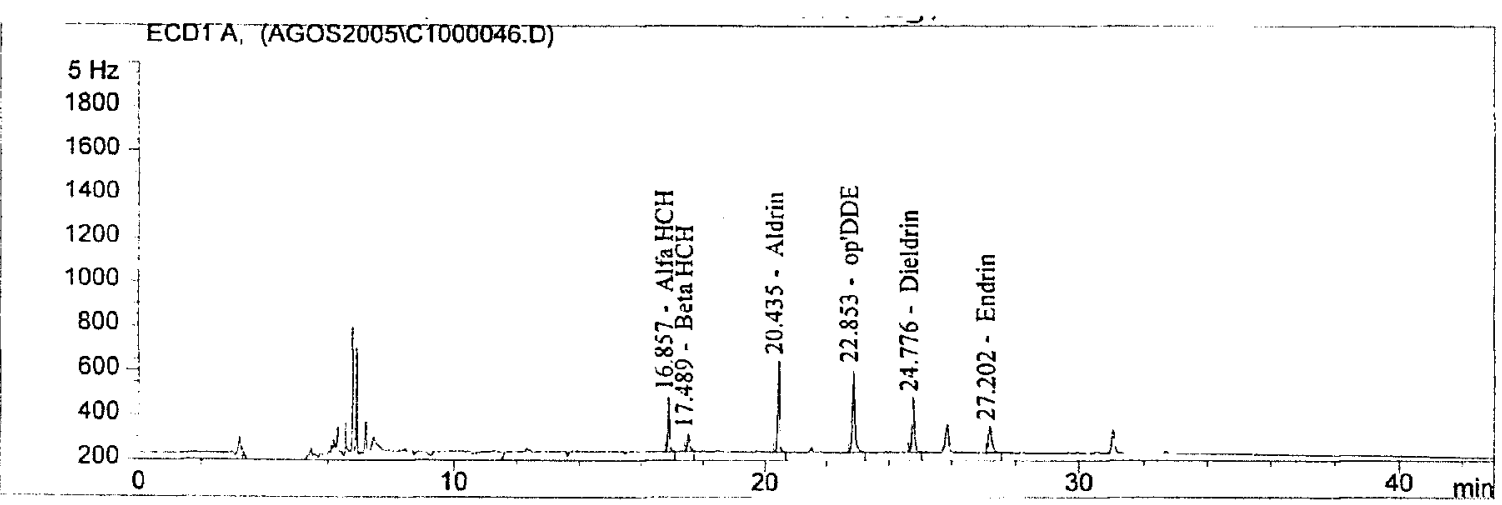

Figura 27: Cromatograma Alfa 2,0pg $\mu \mathrm{L}^{-1}$ e Beta $4,0 \rho g \mu \mathrm{L}^{-1}$.

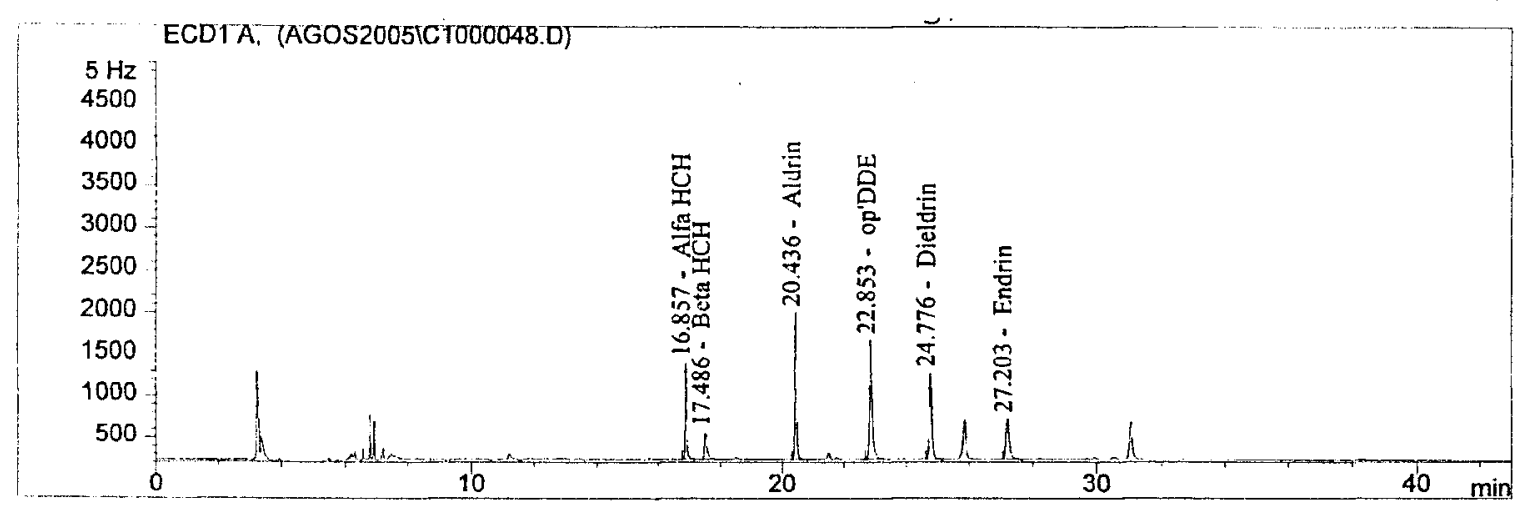

Figura 28: Cromatograma Alfa $10,0 \rho g \mu \mathrm{L}^{-1}$ e Beta $20,0 \rho g \mu \mathrm{L}^{-1}$. 


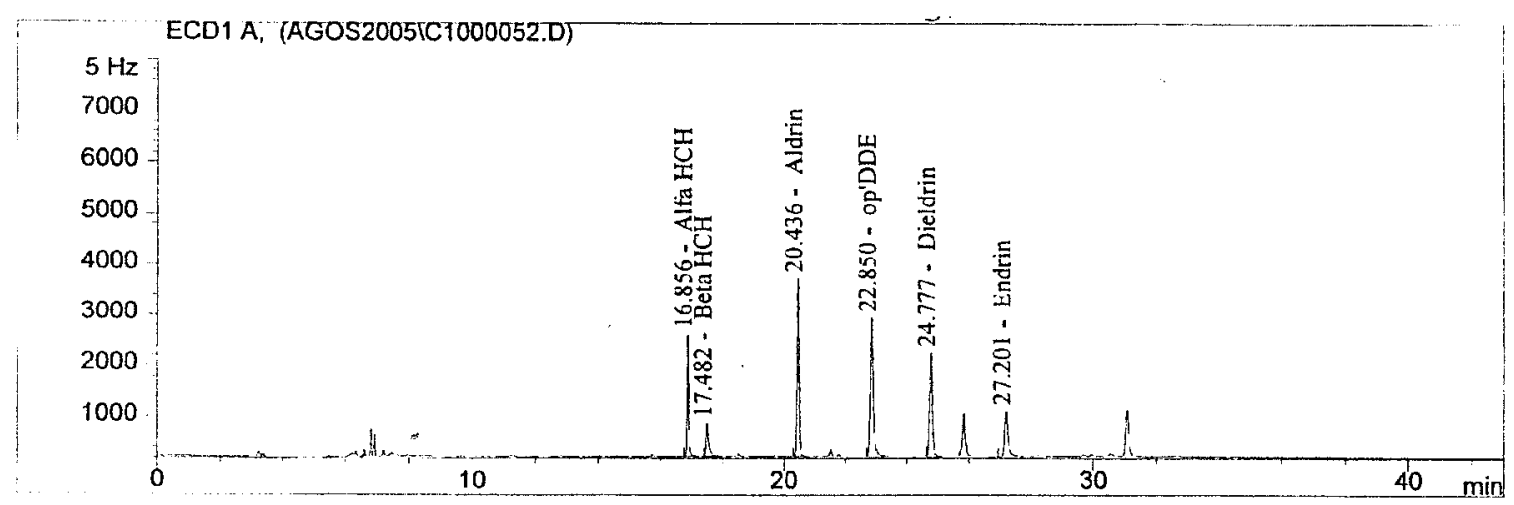

Figura 29: Cromatograma Alfa 20,0pg $\mu \mathrm{L}^{-1}$ e Beta $40,0 \rho g \mu \mathrm{L}^{-1}$.

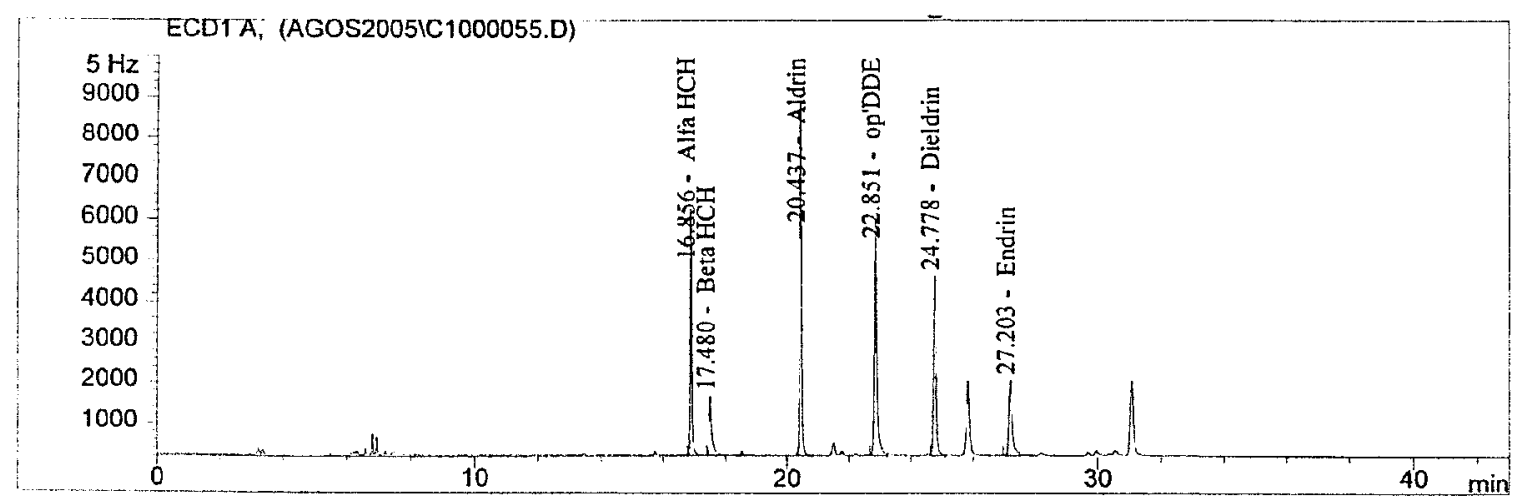

Figura 30: Cromatograma Alfa $50,0 \rho g \mu \mathrm{L}^{-1}$ e Beta $100,0 \rho g \mu \mathrm{L}^{-1}$.

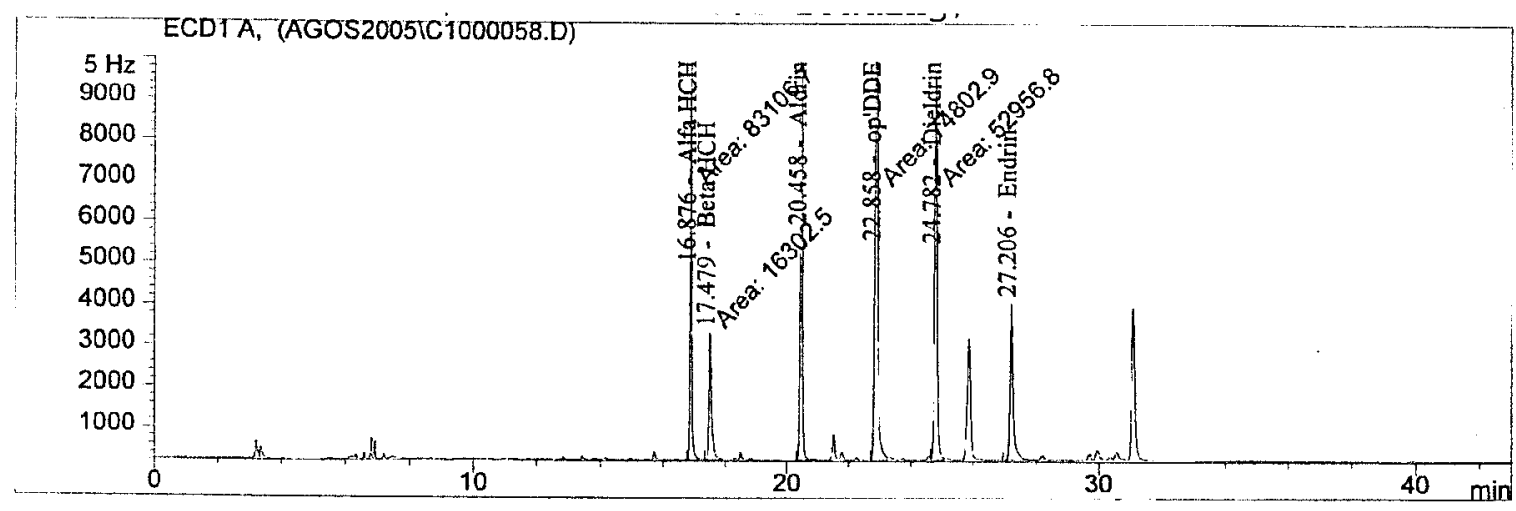

Figura 31: Cromatograma Alfa 100,0pg $\mu \mathrm{L}^{-1}$ e Beta 200,0pg $\mu \mathrm{L}^{-1}$. 


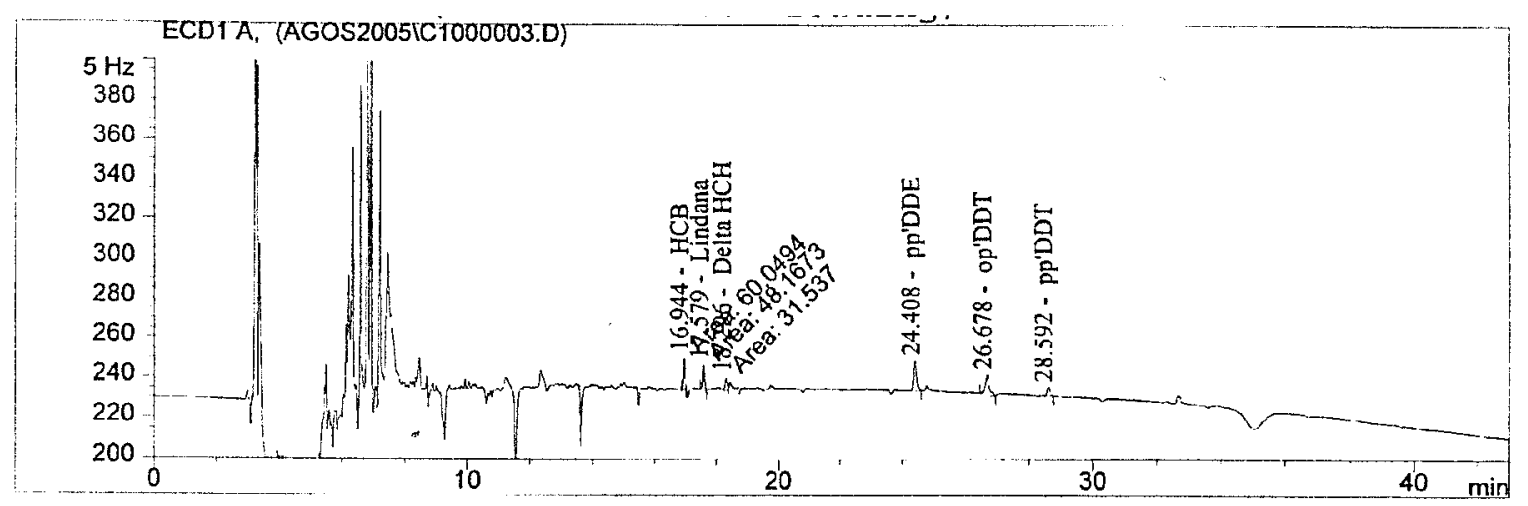

Figura 32: Cromatograma Lindana $0,1 \rho g \mathrm{~L}^{-1}$ e Delta $0,2 \rho g \mu \mathrm{L}^{-1}$.

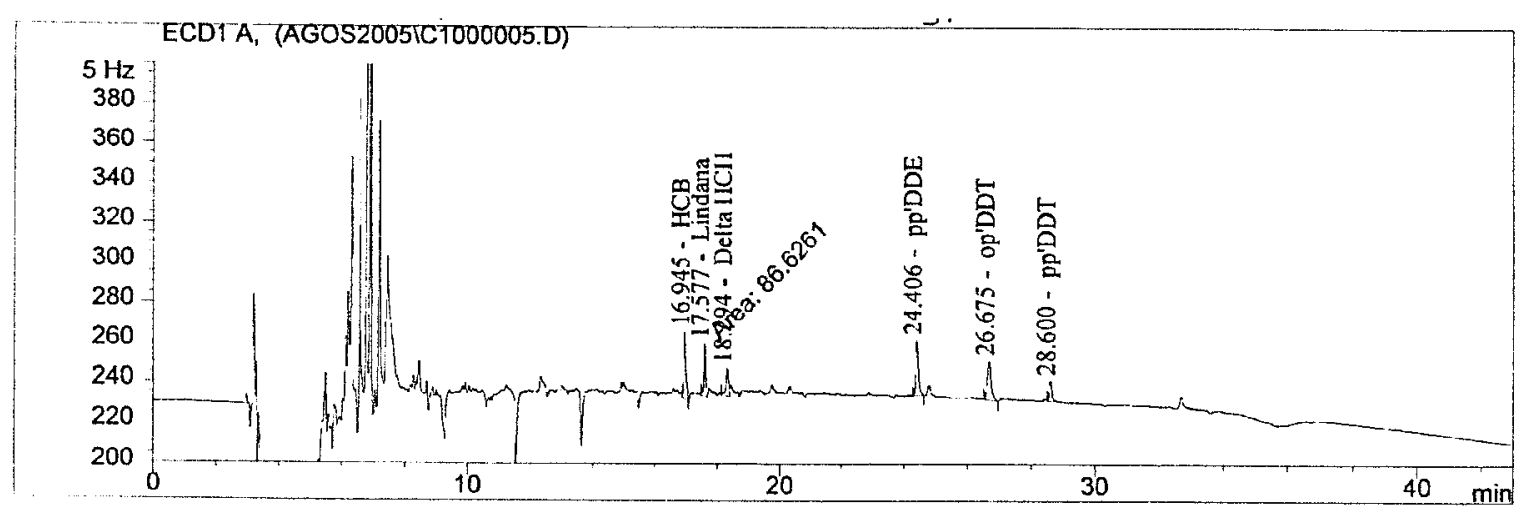

Figura 33: Cromatograma Lindana $0,2 p g \mu \mathrm{L}^{-1}$ e Delta $0,4 \rho g \mu \mathrm{L}^{-1}$.

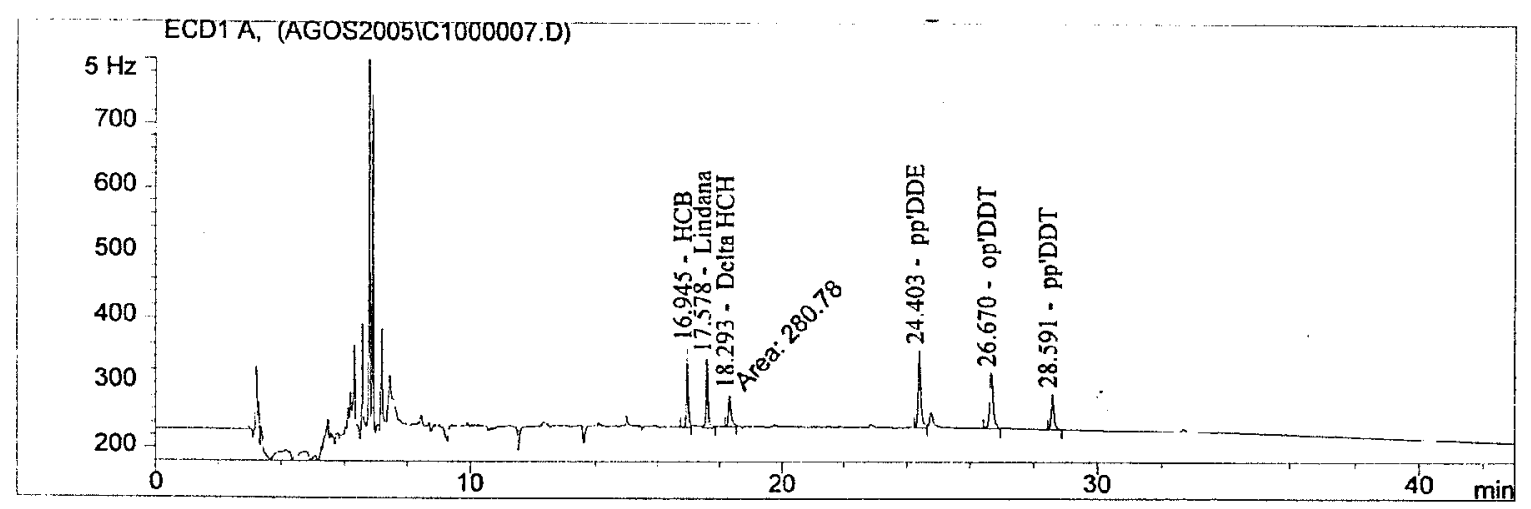

Figura 34: Cromatograma Lindana $1 \rho g \mathrm{~L}^{-1}$ e Delta $2 \rho g \mu \mathrm{L}^{-1}$. 


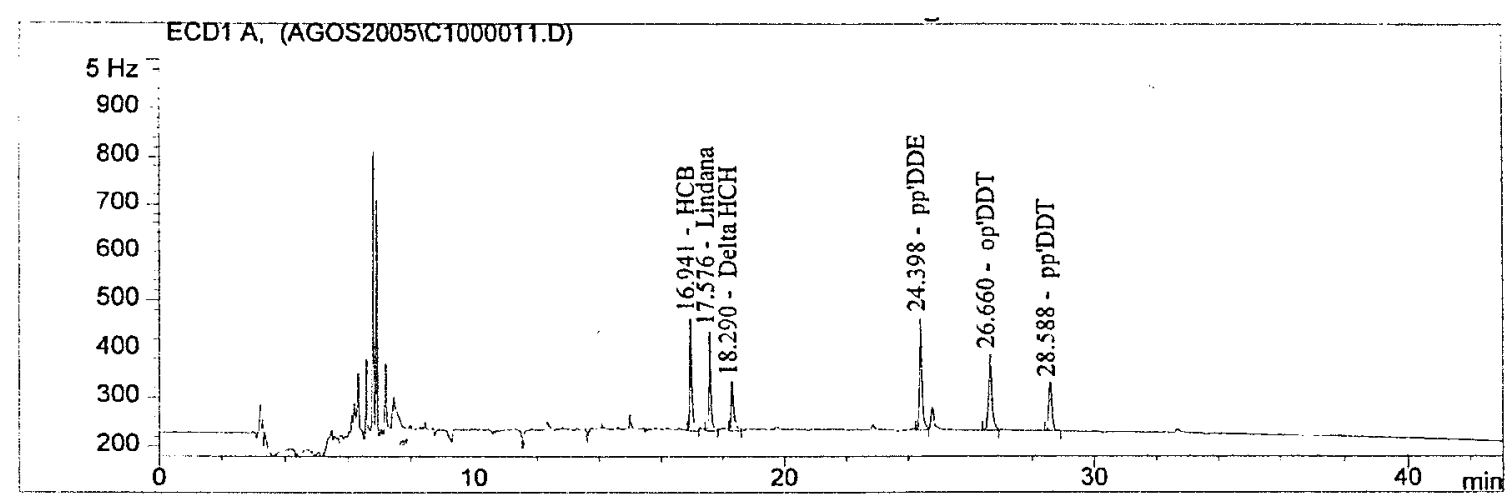

Figura 35: Cromatograma Lindana $2 \rho g \mu \mathrm{L}^{-1}$ e Delta $4 \rho g \mathrm{~L}^{-1}$.

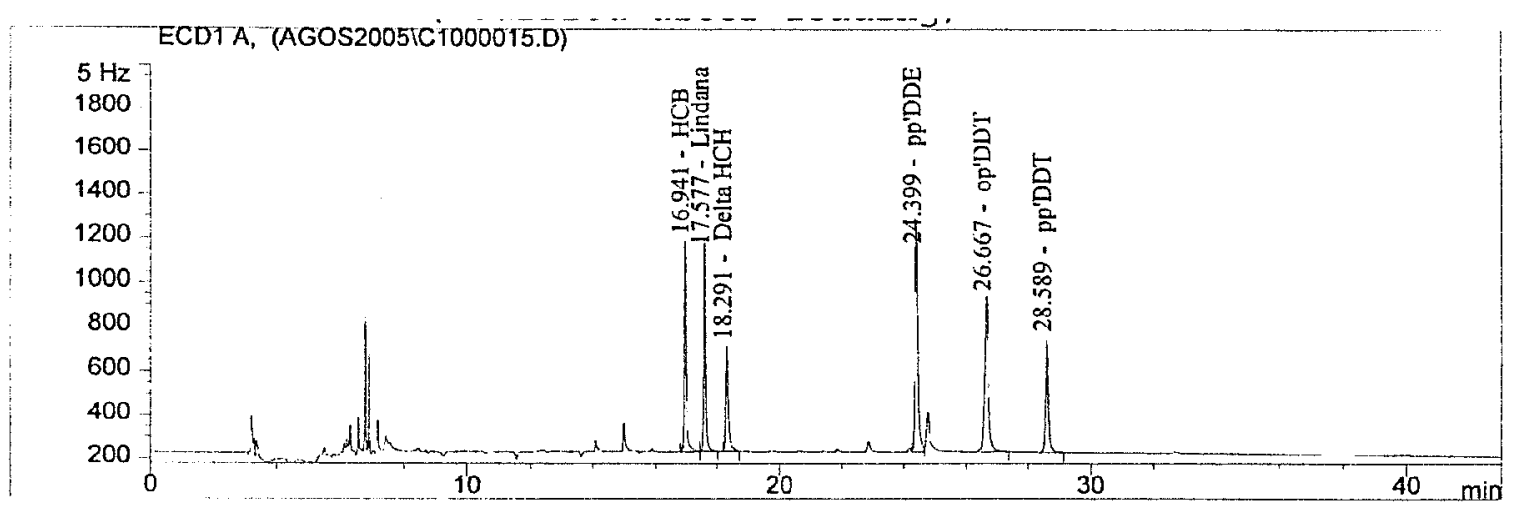

Figura 36: Cromatograma Lindana 10pg $\mu \mathrm{L}^{-1}$ e Delta $20 \rho g \mathrm{~L}^{-1}$.

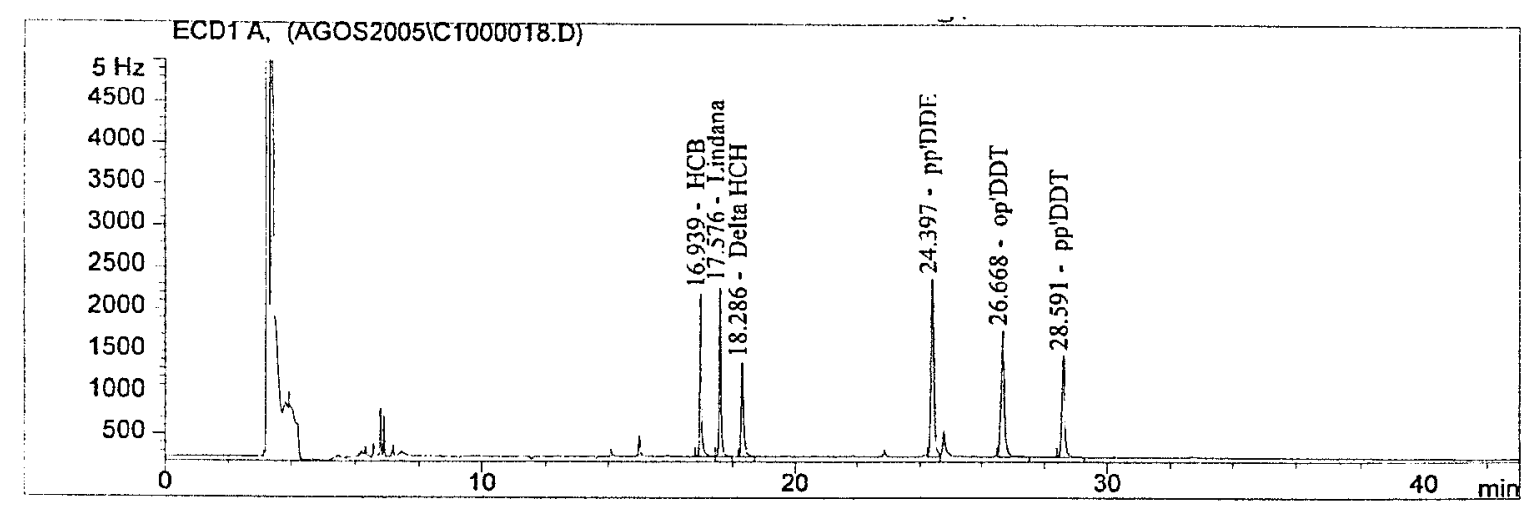

Figura 37: Cromatograma Lindana 20pg $\mu \mathrm{L}^{-1}$ e Delta $40 \rho g \mathrm{~L}^{-1}$ 


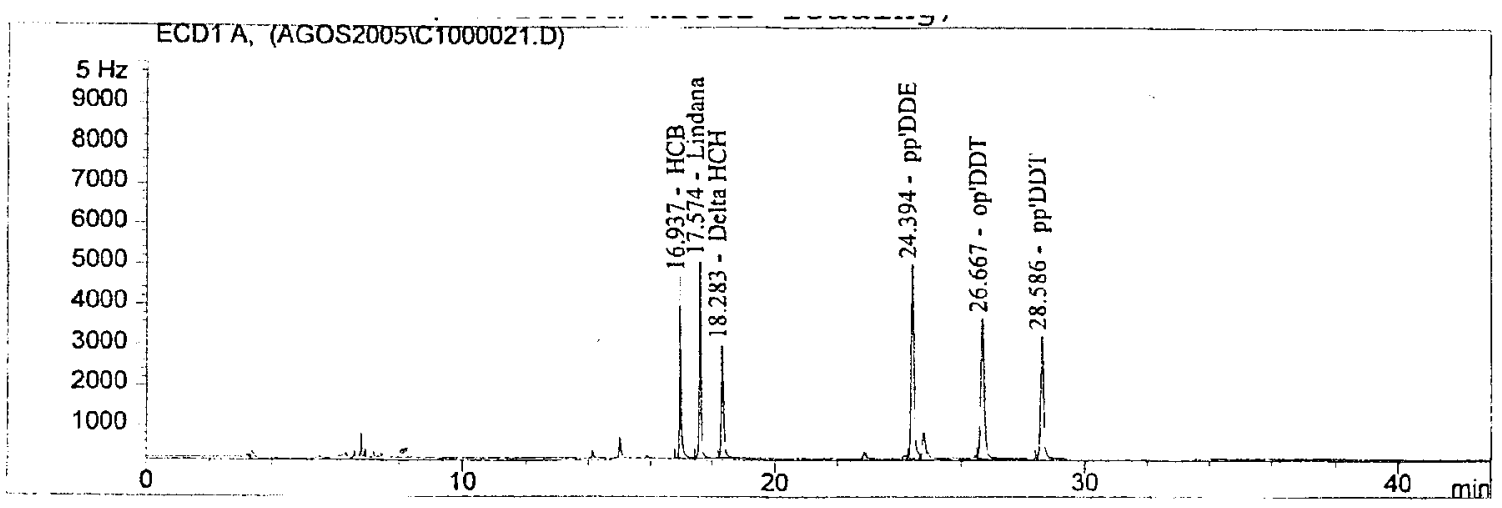

Figura 38: Cromatograma Lindana 50pg $\mu \mathrm{L}^{-1}$ e Delta 100pg $\mu \mathrm{L}^{-1}$.

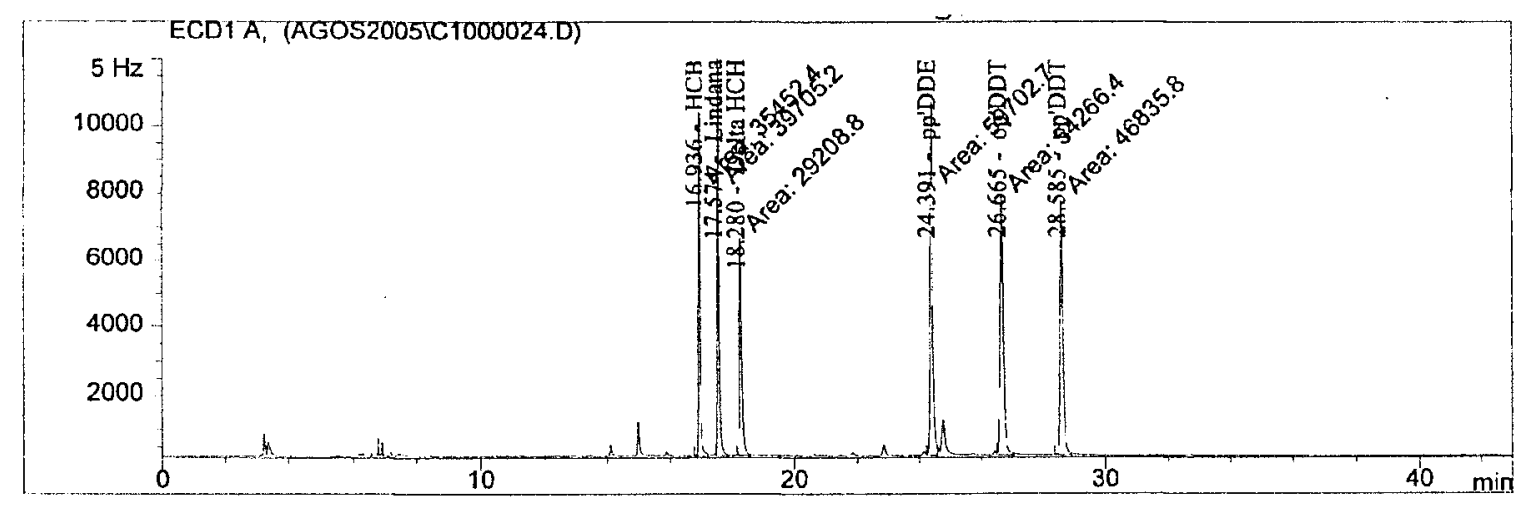

Figura 39: Cromatograma Lindana 100pg $\mu \mathrm{L}^{-1}$ e Delta 200pg $\mu \mathrm{L}^{-1}$.

\subsubsection{Especificidade/Seletividade}

Não foram detectados picos interferentes nas amostras branco que pudessem ser atribuidos ao Hexaclorociclohexano acima do limite de detecção do método nas amostras de soro sangüineo.

\subsubsection{Precisão de Medição/ Exatidão/ Recuperação}

Os limites inferiores e superiores das recuperações nos niveis de fortificação estudados estão apresentados nas tabelas 7, 9, 11 e 13. 
Tabela 7: Eficiência da recuperação para Alfa $\mathrm{HCH}$

\begin{tabular}{cccccc}
\hline $\begin{array}{c}\text { V.A. } \\
\mu \mathbf{g ~ d L}^{-1}\end{array}$ & $\begin{array}{c}\text { V.R. } \\
\mu \mathbf{g ~ d L}^{-1}\end{array}$ & $\%$ & $\overline{\mathbf{x}} \%$ & $\begin{array}{c}\text { D.P. } \\
\%\end{array}$ & $\begin{array}{c}\text { C.V. } \\
\%\end{array}$ \\
\hline 0,04 & 0,030 & 76 & & & \\
\hline 0,04 & $0,037$. & 93 & & & \\
\hline 0,04 & 0,029 & 72 & 78 & 8,7 & 11,2 \\
\hline 0,04 & 0,029 & 74 & & & \\
\hline 0,04 & 0,029 & 73 & & & \\
\hline 0,40 & 0,350 & 88 & & & \\
\hline 0,40 & 0,340, & 85 & & & \\
\hline 0,40 & 0,340 & 85 & 91 & & \\
\hline 0,40 & 0,390 & 98 & & & \\
\hline 0,40 & 0,403 & 101 & & & \\
\hline
\end{tabular}

V.A. Valor adicionado LOQ proposto

V.R. Valor recuperado

$\%$ Valor em porcentagem do ativo recuperado.

$\bar{x} \%$ média de recuperação

D.P. Desvio Padrão

C.V. Coeficiente de variação

Tabela 8: Resultados Globais para Alfa $\mathrm{HCH}$

\begin{tabular}{ll}
\hline Média Global das Recuperações \% & $85 \%$ \\
\hline CV Global das Recuperações \% & $9,8 \%$ \\
\hline
\end{tabular}

Limite de Detecção (LOD)

De acordo com o critério estabelecido temos:

LOD estatístico $=3 \times$ DESVPAD

LOD estatístico $=3 \times 0,003 \mu \mathrm{g} \mathrm{dL}^{-1}$

$\operatorname{LOD}_{\text {instrumental }}=0,001 \mu \mathrm{g} \mathrm{dL}^{-1}$

LOD estatístico $=0,009 \mu \mathrm{g} \mathrm{dL}^{-1}$ 
Temos que: $0,001 \mu \mathrm{g} \mathrm{dL}^{-1}<0,009 \mu \mathrm{g} \mathrm{dL}^{-1}$

Critério a ser adotado: qualificar o LOD para o maior valor encontrado.

Então:LOD $=0,009 \mu \mathrm{g} \mathrm{dL}^{-1}$

Limite de Quantificação (LOQ)

De acordo com o critério estabelecido temos que:

LOQ estatístico $=10 \times$ DESVPAD

LOQ estatístico $=10 \times 0,003 \mu \mathrm{g} \mathrm{dL}^{-1}$

$L O Q_{\text {proposto }}=0,04 \mu \mathrm{g} \mathrm{dL}^{-1}$

LOQ estatístico $=0,03 \mu \mathrm{g} \mathrm{dL}^{-1}$

Temos que: $0,03 \mu \mathrm{g} \mathrm{dL}^{-1}<0,04 \mu \mathrm{g} \mathrm{dL}^{-1}$

Critério a ser adotado: qualificar o $L O Q$ para o maior valor encontrado. $L O Q=0,04 \mu \mathrm{g} \mathrm{dL}^{-1}$ 
Tabela 9: Eficiência da recuperação para Beta $\mathrm{HCH}$

\begin{tabular}{clllll}
\hline $\begin{array}{c}\text { V.A. } \\
\mu \mathrm{g} \mathrm{dL}^{-1}\end{array}$ & $\begin{array}{c}\text { V.R. } \\
\mu \mathrm{g} \mathrm{dL}^{-1}\end{array}$ & \multicolumn{1}{c}{$\%$} & $\overline{\mathbf{x}} \%$ & $\begin{array}{c}\text { D.P. } \\
\%\end{array}$ & $\begin{array}{c}\text { C.V. } \\
\%\end{array}$ \\
\hline 0,08 & 0,096 & 119 & & & \\
\hline 0,08 & 0,097 & 120 & & & \\
\hline 0,08 & 0,096 & 119 & 119 & 0,4 & 0,34 \\
\hline 0,08 & 0,096 & 119 & & & \\
\hline 0,08 & 0,096 & 119 & & & \\
\hline 0,80 & 0,76 & 95 & & & \\
\hline 0,80 & 0,78 & 98 & & & \\
\hline 0,80 & 0,77 & 96 & 99 & & \\
\hline 0,80 & 0,88 & 110 & & & \\
\hline 0,80 & 0,76 & 95 & & & \\
\hline
\end{tabular}

V.A. Valor adicionado LOQ proposto

V.R. Valor recuperado

$\%$ Valor em porcentagem do ativo recuperado.

$\bar{x} \%$ média de recuperação

D.P. Desvio Padrão

C.V. Coeficiente de variação

Tabela10: Resultados Globais para Beta $\mathrm{HCH}$

\begin{tabular}{ll}
\hline Média Global das Recuperações \% & 109 \\
\hline CV Global das Recuperações \% & 3,4 \\
\hline
\end{tabular}

Limite de Detecção (LOD)

De acordo com o critério estabelecido temos:

LOD estatístico $=3 \times$ DESVPAD

LOD estatístico $=3 \times 0,0004 \mu \mathrm{g} \mathrm{dL}^{-1}$

$\operatorname{LOD}_{\text {instrumental }}=0,001 \mu \mathrm{g} \mathrm{dL}^{-1}$

LOD estatístico $=0,0012 \mu \mathrm{g} \mathrm{dL}^{-1}$ 
Temos que: $0,001 \mu \mathrm{g} \mathrm{dL}^{-1}<0,0012 \mu \mathrm{gl}^{-1}$

Critério a ser adotado: qualificar o LOD para o maior valor encontrado.

Então:LOD $=0,0012 \mu \mathrm{g} \mathrm{dL}^{-1}$

Limite de Quantificação (LOQ)

De acordo com o critério estabelecido temos que:

LOQ estatístico $=10 \times$ DESVPAD

LOQ estatistico $=10 \times 0,0004 \mu \mathrm{g} \mathrm{dL}^{-1}$

$L_{\text {proposto }}=0,08 \mu \mathrm{g} \mathrm{dL}^{-1}$

LOQ estatístico $=0,004 \mu \mathrm{g} \mathrm{dL}^{-1}$

Temos que: $0,04 \mu \mathrm{g} \mathrm{dL}^{-1}<0,08 \mu \mathrm{g} \mathrm{dL}^{-1}$

Critério a ser adotado: qualificar o LOQ para o maior valor encontrado.

$\mathrm{LOQ}=0,08 \mu \mathrm{g} \mathrm{dL}^{-1}$ 
Tabela 11: Eficiência da recuperação para Delta $\mathrm{HCH}$

\begin{tabular}{clllll}
\hline $\begin{array}{c}\text { V.A. } \\
\mu \mathrm{g} \mathrm{dL}^{-1}\end{array}$ & $\begin{array}{c}\text { V.R. } \\
\mu \mathrm{g} \mathrm{dL}\end{array}$ & \multicolumn{1}{c}{$\%$} & $\overline{\mathbf{x}} \%$ & $\begin{array}{c}\text { D.P. } \\
\%\end{array}$ & $\begin{array}{c}\text { C.V. } \\
\%\end{array}$ \\
\hline 0,08 & 0,081 & 101 & & & \\
\hline 0,08 & 0,076 & 95 & & & \\
\hline 0,08 & 0,083 & 104 & 101 & 6,7 & 6,6 \\
\hline 0,08 & 0,076 & 95 & & & \\
\hline 0,08 & 0,089 & 111 & & & \\
\hline 0,80 & 0,637 & 80 & & & \\
\hline 0,80 & 0,694 & 87 & & & \\
\hline 0,80 & 0,651 & 81 & 81 & & \\
\hline 0,80 & 0,645 & 81 & & & \\
\hline 0,80 & 0,604 & 76 & & & \\
\hline
\end{tabular}

V.A. Valor adicionado LOQ proposto

V.R. Valor recuperado

$\%$ Valor em porcentagem do ativo recuperado.

$\bar{x} \%$ média de recuperação

D.P. Desvio Padrão

C.V. Coeficiente de variação

Tabela12: Resultados Globais para Delta $\mathrm{HCH}$

\begin{tabular}{ll}
\hline Média Global das Recuperações \% & 91 \\
\hline CV Global das Recuperações \% & 5,7 \\
\hline
\end{tabular}

Limite de Detecção (LOD)

De acordo com o critério estabelecido temos:

LOD estatístico $=3 \times$ DESVPAD

LOD estatístico $=3 \times 0,005 \mu \mathrm{g} \mathrm{dL}^{-1}$

$\operatorname{LOD}_{\text {instrumental }}=0,01 \mu \mathrm{g} \mathrm{dL}^{-1}$

LOD estatístico $=0,015 \mu \mathrm{g} \mathrm{dL}^{-1}$ 
Temos que: $0,01 \mu \mathrm{g} \mathrm{dL}^{-1}<0,015 \mu \mathrm{g} \mathrm{dL}^{-1}$

Critério a ser adotado: qualificar o LOD para o maior valor encontrado.

Então:LOD $=0,015 \mu \mathrm{g} \mathrm{dL}^{-1}$

Limite de Quantificação (LOQ)

De acordo com o critério estabelecido temos que:

LOQ estatístico $=10 \times$ DESVPAD

LOQ estatístico $=10 \times 0,005 \mu \mathrm{g} \mathrm{dL}^{-1}$

$L O Q$ proposto $=0,08 \mu \mathrm{g} \mathrm{dL}^{-1}$

LOQ estatístico $=0,05 \mu \mathrm{gLL}^{-1}$

Temos que: $0,05 \mu \mathrm{g} \mathrm{dL}^{-1}<0,08 \mu \mathrm{g} \mathrm{dL}^{-1}$

Critério a ser adotado: qualificar o LOQ para o maior valor encontrado.

$\mathrm{LOQ}=0,08 \mu \mathrm{g} \mathrm{dL}^{-1}$ 
Tabela 13: Eficiência da recuperação para Gama $\mathrm{HCH}$ - Lindana

\begin{tabular}{clcccc}
\hline $\begin{array}{c}\text { V.A. } \\
\mu \mathrm{g} \mathrm{dL}^{-1}\end{array}$ & $\begin{array}{c}\text { V.R. } \\
\mu \mathrm{g} \mathrm{dL}^{-1}\end{array}$ & \multicolumn{1}{c}{$\%$} & $\overline{\mathbf{x}} \%$ & $\begin{array}{c}\text { D.P. } \\
\%\end{array}$ & $\begin{array}{c}\text { C.V. } \\
\%\end{array}$ \\
\hline 0,04 & 0,042 & 105 & & & \\
\hline 0,04 & 0,042 & 105 & & & \\
\hline 0,04 & 0,039 & 98 & 106 & 5,7 & 5,4 \\
\hline 0,04 & 0,044 & 110 & & & \\
\hline 0,04 & 0,045 & 113 & & & \\
\hline 0,40 & 0,321 & 80 & & & \\
\hline 0,40 & 0,350 & 88 & & & \\
\hline 0,40 & 0,387 & 97 & 86 & & \\
\hline 0,40 & 0,348 & 87 & & & \\
\hline 0,40 & 0,307 & 77 & & & \\
\hline
\end{tabular}

V.A. Valor adicionado LOQ proposto

V.R. Valor recuperado

$\%$ Valor em porcentagem do ativo recuperado.

$\vec{x} \%$ média de recuperação

D.P. Desvio Padrão

C.V. Coeficiente de variação

Tabela 14: Resultados Globais para Gama $\mathrm{HCH}$ - LINDANA

\begin{tabular}{ll}
\hline Média Global das Recuperações \% & 96 \\
\hline CV Global das Recuperações \% & 7,3 \\
\hline
\end{tabular}

Limite de Detecção (LOD)

De acordo com o critério estabelecido temos:

LOD estatístico $=3 \times$ DESVPAD

LOD estatístico $=3 \times 0,002 \mu \mathrm{g} \mathrm{dL}^{-1}$

$L D_{\text {instrumental }}=0,001 \mu \mathrm{g} \mathrm{dL}^{-1}$

LOD estatístico $=0,006 \mu \mathrm{g} \mathrm{dL}^{-1}$ 
Temos que: $0,001 \mu \mathrm{g} \mathrm{dL}^{-1}<0,002 \mu \mathrm{g} \mathrm{dL}^{-1}$

Critério a ser adotado: qualificar o LOD para o maior valor encontrado.

Então:LOD $=0,002 \mu \mathrm{g} \mathrm{dL}^{-1}$

Limite de Quantificação (LOQ)

De acordo com o critério estabelecido temos que:

LOQ estatístico $=10 \times$ DESVPAD

LOQ estatístico $=10 \times 0,002 \mu \mathrm{g} \mathrm{dL}^{-1}$

$L O Q$ proposto $=0,04 \mu \mathrm{g} \mathrm{dL}^{-1}$

$\mathrm{LOQ}$ estatístico $=0,02 \mu \mathrm{g} \mathrm{dL}^{-1}$

Temos que: $0,02 \mu \mathrm{g} \mathrm{dL}^{-1}<0,04 \mu \mathrm{g} \mathrm{dL}^{-1}$

Critério a ser adotado: qualificar o LOQ para o maior valor encontrado.

$\mathrm{LOQ}=0,04 \mu \mathrm{g} \mathrm{dL}^{-1}$ 


\subsection{Resultados Grupo 1 e Grupo 2.}

A população de estudo foi composta por 56 pessoas que trabalharam ou trabalham no Arquivo Histórico de Joinville, estando expostas ao $\mathrm{HCH}$ no seu ambiente de trabalho.

Tabela 15: Grupo 1 - "Grupo Exposto"

\begin{tabular}{llllllll}
$\begin{array}{c}\text { Faixa } \\
\text { Etária }\end{array}$ & $\begin{array}{c}\text { Quantidade } \\
\text { de pessoas }\end{array}$ & \multicolumn{2}{c}{ Sexo } & \multicolumn{3}{c}{ Valor encontrada $\mu \mathrm{dL}^{-1}$} \\
\hline & & M. & F. & $\alpha$ & $\beta$ & $\sigma$ & $\gamma$ \\
\hline 19-29anos & 25 & 11 & 14 & $<0,04$ & $<0,08$ & $<0,08$ & $<0,04$ \\
\hline 30-40anos & 17 & 01 & 16 & $<0,04$ & $<0,08$ & $<0,08$ & $<0,04$ \\
\hline 41-50anos & 06 & 03 & 03 & $<0,04$ & $<0,08$ & $<0,08$ & $<0,04$ \\
\hline 51-60anos & 06 & 03 & 03 & $<0,04$ & $<0,08$ & $<0,08$ & $<0,04$ \\
\hline$>60$ anos & 02 & 02 & 00 & $<0,04$ & $<0,08$ & $<0,08$ & $<0,04$ \\
\hline $\begin{array}{l}\text { Total } \\
\text { M Masculino }\end{array}$ & 56 & 20 & 36 & $<0,04$ & $<0,08$ & $<0,08$ & $<0,04$ \\
F Feminino & & & & & & &
\end{tabular}

O grupo não exposto foi formado por uma amostra probabilística dos funcionários públicos municipais, emparelhados por faixa etária e sexo. A relação entre não expostos e expostos foi de 2:1. 
Tabela 16: Grupo 2 - "Grupo não exposto"

\begin{tabular}{lllllllll}
$\begin{array}{l}\text { Faixa } \\
\text { Etária }\end{array}$ & $\begin{array}{c}\text { Quantidade } \\
\text { de pessoas }\end{array}$ & \multicolumn{2}{c}{ Sexo } & \multicolumn{5}{c}{ Valor encontrada $\mu \mathrm{dL}^{-1}$} \\
\hline & & & & & & & \\
\hline 19-29anos & 50 & F. & a & $B$ & $\sigma$ & $\gamma$ \\
\hline 30-40anos & 34 & 26 & 24 & $<0,04$ & $<0,08$ & $<0,08$ & $<0,04$ \\
\hline 41-50anos & 12 & 03 & 31 & $<0,04$ & $<0,08$ & $<0,08$ & $<0,04$ \\
\hline 51-60anos & 12 & 06 & 06 & $<0,04$ & $<0,08$ & $<0,08$ & $<0,04$ \\
\hline$>60$ anos & 04 & 06 & 06 & $<0,04$ & $<0,08$ & $<0,08$ & $<0,04$ \\
\hline $\begin{array}{l}\text { Total } \\
\text { M Masculino }\end{array}$ & 112 & 04 & 00 & $<0,04$ & $<0,08$ & $<0,08$ & $<0,04$ \\
F Feminino & 45 & 67 & $<0,04$ & $<0,08$ & $<0,08$ & $<0,04$ \\
& & & & & & & &
\end{tabular}




\subsection{DISCUSSÃO DOS RESULTADOS}

$\mathrm{O} \mathrm{HCH}$ - alfa, beta e gama são isômeros mais importantes em termo de impacto ambiental e saúde humana. A estabilidade e lipofilia relativamente alta do $\mathrm{HCH}$ e o seu padrão de uso global resultaram em contaminação ambiental significativa por esse hidrocarboneto clorado.

Uma vez introduzido no ambiente, $\mathrm{OHCH}$ pode persistir por muitos anos. $\mathrm{O}$ isômero beta é mais persistente do que os outros. $\mathrm{O}$ gama-HCH é a forma mais conhecida mundialmente por ser mais tóxico.

$\mathrm{O} \mathrm{HCH}$ é bem absorvido pelo trato gastrointestinal, pulmões e pele. É transportado quase que totalmente ligado a proteínas plasmáticas e todos os isômeros são preferencialmente estocados no tecido adiposo, mas também em outros órgãos como fígado e glândulas adrenais. O seu metabolismo é hepático e sua excreção se dá pela urina, fezes e leite.

Os diferentes isômeros de $\mathrm{HCH}$ acarretam ações farmacológicas opostas. $\mathrm{O}$ isômero gama é estimulante do Sistema Nervoso Central (SNC), causando violentas convulsões epileptiformes, enquanto os isômeros - alfa, beta e delta são principalmente depressores do SNC, podendo levar a flacidez muscular, prostração e dificuldade de marcha.

A toxicidade aguda dos isômeros do $\mathrm{HCH}$ se dá pela ordem decrescente: gama > alfa > delta > beta e na toxicidade crônica, obedece a ordem: beta > alfa > gama $>$ delta.

Foram analisados os quatro isômeros do $\mathrm{HCH}$ e nenhum deles foi detectado, no soro sangüíneo. $O$ isômero Beta é o mais persistente no organismo, mas não foram encontrados resultados positivos de sua presença no limite de quantificação de $0,04 \mu \mathrm{g} \mathrm{dL}^{-1}$ para Alfa $\mathrm{HCH}$ e Lindano e $0,08 \mu \mathrm{g} \mathrm{dL}^{-1}$ para Beta e Delta $\mathrm{HCH}$.

$A$ análise tanto da literatura científica nacional e internacional, atualizadas até o início de 2001, permite formular as seguintes conclusões e recomendações (dirigidas ao Ministério da Saúde):

1 - As substâncias químicas organocloradas e especificamente 0 hexaclorociclohexano $(\mathrm{HCH})$, em seus isômeros alfa-, beta-, gama- (lindana) e no seu "grau técnico", ocupam lugar de destaque nas preocupações do mundo inteiro 
(como no Brasil), quer pela sua persistência no meio ambiente, quer pela sua biopersistência nos seres vivos, e principalmente, por seu potencial impacto para a saúde das populações.

2 - Com efeito, tem sido demonstrada a presença de resíduos organoclorados, incluindo especificamente o $\mathrm{HCH}$, em meios biológicos (sangue, gordura do leite materno, tecido adiposo, etc.) em praticamente $100 \%$ das pessoas, em qualquer parte da Terra.

3 - De um modo geral, observa-se, principalmente em alguns países europeus e norteamericanos, uma tendência de progressiva redução dos níveis de organoclorados - incluindo especificamente $\mathrm{O} \mathrm{HCH}$ - no organismo humano, medida pela concentração destes resíduos nos meios biológicos (sangue, gordura do leite materno, tecido adiposo e outros).

4 - Essa tendência, de progressivo declínio da concentração de resíduos organoclorados no organismo humano, esta associada às proibições de fabricação e uso agrícola dos praguicidas organoclorados, iniciada nos anos 70, e progressivamente estendida ao mundo.

5 - No Brasil, os trabalhos científicos disponiveis - ainda que numerosos e de boa qualidade, não são suficientes para delinear de modo adequado uma tendência temporal de médio e longo prazo, dada a falta de sistematização de estudos populacionais amostralmente representativos e historicamente analisados. Os estudos disponiveis geralmente são geograficamente localizados, e abordam, em sua maioria, grupos populacionais específicos, com ênfase em exposições ocupacionais e exposições no entorno de áreas poluídas, ou em condições nãoestrapoláveis.

6 - Por outro lado, no caso do Brasil, embora a proibição do uso agrícola dos praguicidas clorados já vigore há mais de 15 anos, o quadro tem características mais complexas, tendo em vista o uso extensivo que se fez de praguicidas clorados, para o combate de vetores de doenças infecciosas, em especial a malária e a doença de Chagas.

7 - Sobre os efeitos da exposição ambiental a substâncias químicas organocloradas - nominalmente o $\mathrm{HCH}$ - sobre a saúde humana, a literatura científica compulsada mostrou que eles devem ser analisados e interpretados segundo a natureza da 
exposição (ocupacional, terapêutica, ambiental), a via de penetração no organismo (respiratória, digestiva, dérmica), o tempo de exposição, a dose absorvida, e outras variáveis, tendo sido identificada a ocorrência de confusões conceituais e de freqüentes erros de interpretação.

8 - Do mesmo modo, observou-se uma grande variabilidade de achados em estudos experimentais realizados em animais, de distintas espécies, idades e condições, e grande diferença entre esses achados e o que ocorre no organismo humano, em condições reais.

9 - Corrigidas estas distorções, permanecem no centro das preocupações de saúde humana, os efeitos de médio e longo prazo, em especial os eventuais efeitos sobre o desenvolvimento fetal, os efeitos hormonais (organoclorados como desautores hormonais), e as neoplasias malignas.

10 - No caso das neoplasias malignas, até o momento os achados positivos resumem-se a espécies animais alimentadas com grandes quantidades de $\mathrm{HCH}$, não existindo evidências idôneas, de natureza epidemiológica, que confirmem a carcinogencidade no ser humano. Contudo, por analogia com o que ocorre com outras substâncias químicas tóxicas, a sinalização experimental não pode ser abandonada, principalmente à luz do Princípio da Precaução e no contexto da Vigilância de Saúde.

11 - Estas observações aplicam-se especialmente para o câncer de mama e, secundariamente, para o câncer de fígado, entre outras localizações e tipo de tumores malignos.

12 - Recomenda-se ao Ministério da Saúde uma discussão mais profundada, no curto e médio prazos, sobre questões como:

- Fortalecimento e desenvolvimento de Centros de Registro de Câncer, integrados aos Sistemas de Vigilância, de Morbidade e de Mortalidade, com destaque para a introdução de informações de interesse ocupacional e ambiental.

- Desenvolvimento ou fomento de estudos na direção da constituição de bancos de dados sobre resíduos organoclorados em tecido adiposo, obtido por biopsia intracirúrgica e em autópsias.

- Desenvolvimento ou fomento de estudos na direção da constituição de bancos de dados sobre resíduos organoclorados em gordura de leite materno. 
Ainda que tenham um espectro nacional abrangente, as recomendações constantes no item anterior deveriam ser prioritariamente implementadas no Estado do Rio de Janeiro, iniciando-se pela região Metropolitana do Rio de Janeiro ("Grande Rio"), tendo em vista o interesse do Ministério da Saúde em ampliar o conhecimento do problema dos organociorados em Duque de Caxias, em função do "caso Cidade dos Meninos", Rio de Janeiro, onde uma antiga fábrica desses compostos foi abandonada há quarenta anos, ameaçando seus 1.700 habitantes. Para remediar a área pesadamente contaminada (área foco), um tratamento com óxido de cálcio foi realizado. Análises de solo coletadas superficialmente na área tratada, anos após o tratamento, mostraram ainda altas concentrações residuais de $\mathrm{HCHs}$. Niveis de concentração tão alto quanto $6.200 \mathrm{mg} / \mathrm{Kg}$ e $7.320 \mathrm{mg} / \mathrm{Kg}$ foram encontrados para os isômeros $\alpha-$ e $\beta-H C H$. Para os isômeros $\gamma$ - e $\delta-H C H$, as concentrações observadas foram superiores a $140 \mathrm{mg} / \mathrm{Kg}$ e $530 \mathrm{mg} / \mathrm{Kg}$, respectivamente. Estes resultados mostraram que o tratamento com óxido de cálcio não foi eficiente para a descontaminação do solo desta área. 


\section{CONCLUSÕES}

As principais conclusões deste trabalho foram:

1) Os resultados encontrados na validação do método indicam exatidões suficientes para a finalidade do estudo. O método é considerado adequado para as análises em soro sangüíneo e está dentro dos critérios de conformidade definidos através dos procedimentos operacionais do laboratório e das normas legais em vigor no pais. No total foram analisadas 168 (cento e sessenta e oito) amostras de soro sangüíneo, sendo 56 de funcionários e ex-funcionários do Arquivo Histórico de Joinville Santa Catarina e 112 da população controle.

2) Todas as amostras de soro sangüíneo obtiveram resultados abaixo do limite de quantificação de $0,04 \mu \mathrm{g} \mathrm{dL}^{-1}$ para Alfa $\mathrm{HCH}$ e Lindano e $0,08 \mu \mathrm{g} \mathrm{dL}^{-1}$ para Beta e Delta $\mathrm{HCH}$.

3) Embora o trabalho tenha sido feito em dois grupos de fortificações, onde $o$ primeiro consta de Alfa e Beta $\mathrm{HCH}$ e o segundo Delta $\mathrm{HCH}$ e Lindano, é possivel estabelecer o método multiresiduos para os quatros isômeros.

4) $\mathrm{O} \mathrm{HCH}$ é bastante estável, não acarretando problemas de degradação no manuseio dos padrões, e amostras fortificadas até o momento da injeção.

5) Como visto nos cromatogramas houve a inclusão de 16 organoclorados na validação, porém os mesmos não foram identificados em nenhuma das amostras analisadas. A rampa cromatográfica foi estabelecida com aproximadamente 40 minutos, sendo possível a identificação de 16 organoclorados persistente são eles: HCB Hexaclorobenzeno, HCH Hexaclorociclohexano - ALFA - BETA - DELTA e LINDANA, Aldrin, Dieldrin, Endrin, Hepatclor, Heptaclor Epóxido, Mirex, DDT (op'e pp'), DDE (op'e pp') e DDD (op'e pp'). Houve a separação em dois grupos pelo motivo do tempo de retenção estar bem próximo como foi o caso do Alfa e Beta, Delta e Lindana para facilitar a visualização, porém a identificação pode ser feita por uma única corrida e quando houver a necessidade a confirmação em Cromatografia a Gás acoplada a espectrometria de massas (GC-MS).

6) Os dados apresentados na validação estão de acordo com os critérios de ensaio estabelecidos para pesticidas no Brasil. 
7) O resultado negativo dos ativos estudados não indicam que não houve a contaminação, mas que a quantidade de Hexaclorociclohexano no soro sangüíneo dos funcionários e ex - funcionários do Arquivo Histórico de Joinville atualmente, é menor que o limite de quantificação de $0,04 \mu \mathrm{g} \mathrm{dL}^{-1}$ para Alfa $\mathrm{HCH}$ e Gama $\mathrm{HCH}$ "Lindana" e 0,08 $\mu \mathrm{g} \mathrm{dL}^{-1}$ para Beta e Delta $\mathrm{HCH}$. O caso de possivel contaminação ocorreu há 20 anos, e embora estudos de estabilidade da molécula mostrem que, no organismo humano e meio ambiente pode haver persistência por mais de 20 anos, esta estabilidade depende de diversos fatores como alimentação, obesidade, atividades esportivas entre outros.

Desta forma, são necessários estudos mais detalhados avaliando a presença dos isômeros do $\mathrm{HCH}$ nas células adiposas da população exposta, uma vez que o $\mathrm{HCH}$ é lipofílico e poderia estar bioacumulado nestes tecidos.

\section{PERSPECTIVAS}

O caso de possivel contaminação ocorreu há 20 anos, e embora estudos de estabilidade da molécula mostrem que, no organismo humano e meio ambiente pode haver persistenncia por mais de 20 anos, esta estabilidade depende de diversos fatores como alimentação, obesidade, atividades esportivas entre outros.

Desta forma, são necessários estudos mais detalhados para avaliar a presença dos isômeros do $\mathrm{HCH}$ nas células adiposas da população exposta, uma vez que o $\mathrm{HCH}$ é lipofílico e poderia estar bioacumulado nestes tecidos. 


\section{REFERÊNCIAS BIBLIOGRÁFICAS}

AGENCY FOR TOXIC SUBSTANCES AND DISEASE REGISTRY - ATSDR. Toxicological profile for hexachlorobenzene. Atlanta, publication TP 90 17.(1990)

AGENCY FOR TOXIC SUBSTANCES AND DISEASE REGISTRY. Hexachlorocyclo-hexane. ATSDR Public Health Statement, December 1989. Disponivel em http://www.atsdr.cdc.gov/ToxProfiles/phs8914.html.

AHLB ORG;V:G:, LIPWORTH: L, TITUS-ERNSTOFF; L:; HSIEH; C:C:; HAMBERG; A:,BARON; J:, TRICHOPOULOS; D:, ADAMI; H:O. Organochlorine compounds in relation to breast cancer, endometrial cancer and endometriosis: an assessment of the biological and epidemiological evidence. Crit. Rev. Toxicol. 25(6):463-531.(1995)

ALMEIDA; W:F. E COL. DDT residues in human blood serum in Brasil. Environ. Qual. Saf. 3 (suppl): 586-588.(1975).

ALMEIDA, W. F. Níveis sangüíneos de DDT em indivíduos profissionalmente expostos e em pessoas sem exposição direta a este inseticida no Brasil. São Paulo, 1972. Tese (Doutorado) - Faculdade de Saúde Pública, USP, São Paulo.

ALMEIDA, W. F.; MELLO, D.; PUGA, F. R. et al. Intoxicações profissionais por pesticidas. In: MENDES, R. (Ed.) Medicina do Trabalho: Doenças Profissionais. São Paulo: Sarvier, p. 511-69 (1980).

ANDREWS; J.E. \& COURTNEY, K.D. Hexachlorobenzene-induced renal maldevelopment in CD-1 mice and $C D$ rats. In: Hexachlorobenzene: proceedings of an International Symposium. Lyon, Morris, C.R.P. ed., IARC Scientific Publication n. 77, p.381-391.(1986)

ANGERER, J:, HEINZOW, B.; REIMANN; D.O.; KNORZ.; LEHNERT; G. Internal exposure to organic substences in a municipal waste incinerator. Int. Arch. Occup. Environ. Health, 64:265-273. (1992).

ARAUJO, A.C.P.; TELLES, D.L.; GORNI, R.; LIMA, L.L.A. Organochlorine pesticides contamination the Ipojuca basin, Brasil. In: Workhop on Pesticides: Uses and Environmental Safety in Latin America. Sao Paulo. Book of abstracts. P.27. (1996).

AUGUSTO, L. G. S. Exposição ocupacional a organoclorados em indústria química de Cubatão. Campinas, 1995. Tese (Doutorado) - Faculdade de Ciências Médicas da UNICAMP, Campinas, SP.

AUGUSTO, L. G. S.; FREITAS, C. M. O principio da precaução no uso de indicadores de riscos químicos ambientais em saúde do trabalhador. Ciências 
de Saúde Coletiva, v. 3, n. 2, p. 85-95, (1998).

AXELSON, O. Areview of Porphyria and câncer and missing link with human exposure to hexachlorobenzene. In: hexachlorobenzene: proceeding of an International Symposium. Lyon. Morris, C.R. \& Cabral, J.R.P. ed., IARC Scientific Publication n.77, p. 585-589.(1986).

BARRETO, H.H.C.; INOMATA, O.N.K.; LEMES, V.R.R. Níveis de pesticidas organoclorados em.gordura de frango, 1988 - 1991. Rev. Inst. Adolfo Lutz, 52 (1/2):97-100. (1992).

BARRETO, H.H.C.; INOMATA, O.N.K.; et.al. Concentração sangüineo de metais pesados e praguicidas organoclorados em crianças de 1 a 10 anos. Rev. Saúde Pública, 27 (1):59-67. (1993).

BARRETO, H.H.C., et al. Estudo comparativo de métodos para determinação de resíduos de pesticidas organoclorados. Rev. Inst. Adolfo Lutz, v. 51n1-2, p 6974. (1991).

BARRETO, H.H.C., ALLELUIA; I.B. et al. Level of organochlorine pesticides in the blood serum of agricultural workers from Rio de Janeiro state Brazil. Reports in public health. Environmental and occupational cancer in latin America. $V$ 14, p33. (1998).

BARRETTO, H. H. C.; INOMATA, O. N. K.; LEMES, V. R. R. Niveis de pesticidas organo-clorados em gordura de frango, 1988-1991. Revista do Instituto Adolfo Lutz; v. 52, n. 1/2, p. 97-100. (1992).

BASTOS, L. H. P. Investigação da contaminação do solo por organoclorados, na Cidade dos Meninos, em Duque de Caxias, Rjo de Janeiro: avaliação dentro de um novo cenário, após adição de cal. Rio de Janeiro, 1999. Dissertação (Mestrado) - Escola Nacional de Saúde Pública, FIOCRUZ, Rio de Janeiro.

BAROTTO, A.M. Exposição ocupacional a inseticidas organoclorados. Dissertação - Universidade Federal de Santa Catarina. (2003).

BRAHAMS, D. Lindane exposure and aplastic anaemia [news]. Lancet, v. $343, n$. 8905, p. 1092, 1994.

BRASIL. Ministério da Agricultura. Decreto 329, de 2 de setembro de 1985. Diário Oficial da União, 3 de setembro de 1985, Seção I, p. 12941.

CARVALHO, J. P. P.; NISHIKAWA, A. M.; ARANHA, S. et al. Resíduos de praguicidas organoclorados em gordura bovina. Biológico,v. $50, n .2$, p. 39-48, (1984).

CARVALHO, W.A., LIMA, J.M, REBERT, P.R.; ROCHA, N.V.P. Alterações bioquímicas e hematológicas em indivíduos ocupacionalmente expostos ao 
HCH e ao DDT. Rev. Soc Brás Toxicol. 1 (1): 60-64. (1988).

CARVALHO, W.A. Exposição ambiental a inseticidas organoclorados na população do sul da Bahia - Brasil. Rev Soc Bras Toxicol. 1 (1,2): 64-66. (1998)

CARVALHO, W. A. Estudo da exposição ocupacional e ambiental ao HCH (hexacloro-ciclohexano) e ao DDT (2,2-bis-(p-clorofenil) - 1,1,1-tricloroetano) na região Sul do Estado da Bahia. 1987. Dissertação (Mestrado) - Instituto de Química da UFBa, Salvador.

CARVALHO, W. A.; BERBERT, P. R.; ROCHA, N. V. P. Alterações bioquímicas e hematológicas em indivíduos ocupacionalmente expostos ao hexaclorociclohexano e ao DDT. Revista da Sociedade Brasileira de Toxicologia, v. 1, n. $1 / 2$, p. $60-4,(1988)$.

CIOLA, Remolo. Fundamentos da Cromatografia a Gás. São Paulo SP (1985).

DALE, W.E. \& MILLES, J.W. Quantitative method for determination of DDT and DDT metabolites in blood serum. J. Assoc. off. Anal. Chem., 53:1287-1292. (1979).

DELGADO, I.F., Barreto H.H.C, et al. Serum levels of organochlorine pesticides and polychlorinated biphenyls among in habitants of Greater Metropolitan Rio de Janeiro, Brazil. Cad Saúde Pública; 18 (2): 519-524. (2002).

DDT and its Derivatives. Environmental Health Criteria 9. World Health Organization Geneva. (1979).

DEMERS, A.; AYOTTE, P.; BRISSON, J. et al. Risk and aggressiveness of breast cancer in relation to plasma organochlorine concentrations. Cancer Epidemiology Biomarkers Prevention, v. 9, n. 2, p. 161-6, (2000).

DICH, J.; ZAHM, S. H.; HANBERG, A. et al. Pesticides and cancer. Cancer Causes Control, v. 8, n. 3, p. 420-43, (1997).

ENVIRONMENTAL PROTECTION AGENCY - $1,2, \quad 3,4,4,6$, hexachlorocyclohexane (all stereo isomers) (Lindane). Unified Air Toxics Website (UATW). 2001. Disponível em: http://www.epa.gov/ttn/uatw/ht/hef/lindane.html.

FAO Food and Agriculture Organization. Agricultural database, 2003. Disponível em: http://www.fao.org

FERNICOLA, N. A.; AZEVEDO. F. A. Serum levels of organochlorine insecticides in humans in São Paulo, Brasil. Veterinary and Human Toxicology, v. 24, p. 91-3, (1982).

FILHO, E.S. Determinação do grau de exposição interna aos praguicidas organoclorados, em população residente sobre aterro a céu aberto na 
localidade de Pilões, Cubatão - SP/Brasil. Tese apresentada à faculdade de Saúde Pública da universidade de São Paulo para obtenção do Grau de Doutorado. (1998).

FRANKLIN, H. M. O. H.; PEIXOTO, T. M. A.G. Niveis sangüineos de $H C H$ e DDT em guardas da SUCAM. Revista da Sociedade Brasileira de Toxicologia, v. 1, n.1/2, p. 6-8, (1988).

FUNDACENTRO Prevenção de acidentes no trabalho com agrotóxicos; segurança e saúde no trabalho, n.3. São Paulo: Fundação Jorge Duprat Figueiredo de Segurança e Medicina do Trabalho, Ministério do Trabalho, (1998).

FURST, FURST \& WILMERS, 1994. Human milk as a bioindicator for body burden of PCDDs, PCDFs, organochlorine pesticides, and PCBs. Environmental Health Perspectives, Suplemento 1 v. 102, p. 187-93. (1994).

GALLELLI, G.; MANGINI, S.; GERBINO, C. Organochlorine residues in human adipose and hepatic tissues from autopsy sources in northern Italy. Journal of Toxicology and Environmental Health, v. 46, n. 3, p. 293-300, 1995.

GONÇALVES, F. M. Estudo clínico-epidemiológico em trabalhadores de campanha de saúde pública expostos cronicamente a inseticidas - SUCEN. São José do Rio Preto, SP. Ribeirão Preto, 1991. Dissertação (Mestrado) Faculdade de Medicina de Ribeirão Preto, USP.

GUTTES, S.; FAILING, K; NEUMANN, K. et al. Chlororganic pesticides and polychlorinated biphenyls in breast tissue of women with benign and malignant breast disease. Archives of Environmental Contamination and Toxicology, v. 35, n. 1, p. 140-7, 1998.

HOYER, A. P.; GRANDJEAN, P.; JORGENSEN, T. et al. Organochlorine exposure and risk of breast cancer. Lancet, v. 352, n. 9143, p. 1816-20, 1998.

INTERNATIONAL OCCUPATIONAL SAFETY AND HEALTH INFORMATION CENTRE - Lindane. October 1994. Disponível em:

http://www.ilo.org/public/english/... s/icsc/dtasht/ icsc0053.htm.

IARC International Agency for Reseaech um Cancer. Overall evaluation of. Carcinogenicity: an updating of. IARC monographs. IARC Monographs, Suplemento 7, p. 440, Lyon, (1987).

IARC International Agency for Reseaech um Cancer. DDT and associated compound (Review). Occuparional exposures in inseticida application and some pesticidas. IARC Monographs, v.53, p. 179-249, Lyon, (1991).

INFORMATIVO CRQ III. O dilema do uso de defensivos agrícolas. Rio de Janeiro: Conselho Regional de Química, III Região, (1997). 
JOSHI, P. L. et al. A community-based study on the effect of hexachlorocyclohexane $(\mathrm{HCH})$ exposure in spraymen and general population. Journal of Community Diseases, v. 28, n. 3, p. 189-98, (1996).

JUNG, D. et al. Elimination of beta-hexachlorocyclohexane in occupationally exposed persons. Journal of Toxicology and Environmental Health, v. 51, n. 1, p. 23-34, (1997).

KARMAUS, W.; WÖLF, N. Reduced birthweight and length in the offspring of females exposed to PCDFs, PCP, and lindane. Environmental Health Perspective, v. 103, n. 12, p. $1120-5,(1995)$.

LANÇAS, F.M. Cromatografia em fase gasosa, Universidade de São Paulo Instituto de Física e Química de São Carlos, Acta, (1993).

LANE, J.E., Lassiter C.C., Gresen, K.W., Glasgow, W.C. Suspected chronic organochlorine pesticide poisoning Arch Environ Health. 57(2): 174-175. (2002)

LARA, W.H.; BARRETTO, H.H.C.; INOMATA, O.N.K.. Niveis de pesticidas organoclorados em soro sanguineo de pessoas expostas á doenças de chagas no Brasil. Revista Instituto Adolfo Lutz 47 (1/2): 19-24. (1987).

LARA, W.H.; BARRETTO, H.H.C.; INOMATA, O.N.K. Residuos de pesticidas organoclorados em leite humano, São Paulo, Brasil, 1979-1981. Revista Instituto Adolfo Lutz, 42 (1/2): 45-52. (1982).

LARA, W.H.; BARRETTO, H.H.C.; INOMATA, O.N.K.. Niveis de Dieldrin em sangue de aplicadores de Aldrin na região de São José do Rio Preto, São Paulo. Revista Instituto Adolfo Lutz 41(1): 9-14. (1981).

MANUAL OF ANALYTICAL METHOD FOR THE ANALYSIS OF PESTICIDE RESIDUES IN HUMAN AND ENVIRONMENTAL SAMPLE - USEPA, Environmental Toxicology Division Research, Triangle Park N.C. 27711.

MENDONCAS; G.A.S. Pesticidas e Câncer de Mama - um estudos casocontrole no Rio de Janeiro. Tese - Faculdade de Medicina da Universidade de São Paulo para obtenção do título de doutor em medicina. (1997).

NUNES, F.P. Avaliação clínico-ocupacional de trabalhadores expostos ao DDT em programas de saúde pública. Monografia - Faculdade de Ciência da Saúde de Brasília como requisito parcial para obtenção do título de Especialista em Medicina do Trabalho. (2002).

OLIVEIRA, J. M. B.; SOARES, I. A. A.; SILVA, Z. L. Determinação dos níveis séricos de inseticidas organoclorados em indivíduos não expostos da Faculdade de Farmácia da UFMG. Revista de Farmácia e Bioquímica, v. 8, n. 1/2, p. 79-86. (1987). 
OLIVEIRA, M. A. G.; DORES, E. F. G. C. Níveis de praguicidas organoclorados no leite materno de uma população de Cuiabá - Mato Grosso. Pesticidas, v. 8, p. 77-90. (1998).

OLIVEIRA, R. M. Estudo da contaminação do solo e pasto por hexaclorociclohexano $(\mathrm{HCH})$ na Cidade dos Meninos em Duque de Caxias, $R J$. Rio de Janeiro, 1994. Dissertação (Mestrado) - Escola Nacional de Saúde Pública, FIOCRUZ, Rio de Janneiro.

OLIVEIRA, R. M.; BRILHANTE, O. M.; MOREIRA, J. C. et al. Contaminação por hexaclorociclohexanos em área urbana da região Sudeste do Brasil. Revista de Saúde Pública, v. 29, n. 3, p. 228-33. (1995).

OPAS ORGANIZAÇÃO PANAMERICANA DE SAÚDE: Manual de vigilância da saúde de população expostas a agrotóxicos. Representação do Brasil, p. 69, Brasilia, (2000).

PAUMGARTTEN, F.J.R.; et al. Level of organochlorine pesticides in the blood serum of agricultural workers from Rio de Janeiro States, Brazil. Resorts in Public Health. 14 (sup.3): p. 33-39. (1998).

PAUMGARTTEN, F. J.; CRUZ, C. M.; CHAHOUD, I. et al. PCDDs, PCDFs, PCBs, and other organochlorine compounds in human milk from Rio de Janeiro, Brazil. Environmental Research, v. 83, n. 3, p. 293-7, 2000.

PERES, F. (org). É veneno ou remédio. Agrotóxicos, saúde e ambiente. Rio de Janeiro; Editora Fiocruz, (2003).

RADOMSKI, J. L. et al. Pesticide concentrations in the liver, brain and adipose tissue of terminal hospital patients. Food and Cosmetics Toxicology, v. 6, p. 20920. (1968).

RATHORE, M. et al. Burden of organochlorine pesticides in blood and its effect on thyrid hormones in women. The science of the total Environment 295 p. 207215. (2002).

SANTOS FILHO, E. et al. Concentrações sangüíneas de metais pesados e praguicidas organoclorados em crianças de 1 a 10 anos. Revista de Saúde Pública, v. 27, n. 1, p. 59-67. (1993).

SCHADE, G.; HEINZOW, B. Organochlorine pesticides and polychlorinated biphenyls in human milk of mothers living in northern Germany: current extent of contamination, time trend from 1986 to 1997 and factors that influence the levels of contamination. Science of Total Environment, v. 215, n. 1/2, p. 31-9. (1998).

SILVA, A. S., BARRETO, H.H.C., LEMES, V.R.R., KUSSUMI, T.A. Determinação da 
exposição humana a hexaclorobenzeno, em Sítio com resíduos químicos industriais orgaclorados na Localidade de Samaritá, município de São Vicente, São Paulo, Brasil. Rev. Adolfo Lutz. (1997).

SMITH, A.G. Chlorinated Hydrocarbon Insectides. In: Hayes Jr, W.J., Laws Jr, E.R., editors Handbook of Pesticide Toxicology. New York: Academic Press; v.2, p.731-816. (1991).

STEINMETZ, R. et al. Novel estrogenic action of the pesticide residue betahexachloro-cyclohexane in human breast cancer cells. Cancer Research, v. 56, n. 23, p. 6503-9. (1996).

THORPE, E.; WALKER, A. I. T. The toxicology of dieldrin. II - Comparative longterm oral toxicity studies in mice with dieldrin, $D D T$, phenobarbitone, beta-BHC, and gamma-BCH. Food and Cosmetics Toxicology, v. 11, p. 433-42. (1973).

TOLEDO, H.H.B., et al Critérios mínimos para a condução de Estudos de Resíduos. São Paulo. Associação Grupo de Analista de Resíduos de Pesticidas GARP. (2002).

VAN ERT, M.; SULLIVAN Jr., J. B. Organochlorine pesticides. In: SULLIVAN Jr., J. B.; KRIEGER, G. R. (Eds.). Hazardous Materials Toxicology: Clinical Principles of Environmental Health. Baltimore: Williams \& Wilkins, p. 1027-53.(1992)

VANNUCHI, M. T. O.; ANTUNES, L. A. F.; PINOTTI, M. H. P. Resíduos de pesticidas organoclorados em leite materno no município de Londrina, PR. Semina, v. 13, n. 2, p. 52-7. (1992).

WORLD HEALTH ORGANIZATION. Alpha - and Beta - Hexachlorocyclohexanes (Alpha - and Beta - HCHs) Health and Safety Guide. Geneva: IPCS; WHO, 1991. (Health and Safety Guide 53).

WORLD HEALTH ORGANIZATION. Alpha- and Beta- Hexachlorocyclohexanes. Geneva: IPCS; WHO, 1991. 123 p. (Environmental Health Criteria 123).

WORLD HEALTH ORGANIZATION. Lindane (Gamma-HCH) Health and Safety Guide. Geneva: IPCS; WHO, 1991. (Health and Safety Guide 54).

WORLD HEALTH ORGANIZATION. Lindane. Geneva: IPCS; WHO, 1991. 208 p. (Environmental Health Criteria 124).

ZHENG, T. et al. Beta-benzene hexachloride in breast adipose tissue and risk of 102breast carcinoma. Cancer, v. 85, n. 10, p. 2212-8. (1999). 
Instituto de Pesquisas Energéticas e Nucleares

Diretoria de Ensino \& Informação Clentifica e Tecnológica

Av. Prof. Lineu Prestes, 2242 Cidade Universitária CEP: 05508-000

Fone/Fax(OXX11) 3816 - 9148

SÃo PAULO - São Paulo - Brasil

http: //www.Ipen.br

O Ipon 6 uma autarquia vinculada a secrataria de Ćiencia, Tecnologia e Dosenvolvimanto Economico do Estado de sto Paulo, gerida thenica, administrativa e financeiramente pela

Comissto Nacional de Energia Nuclear, orglio do Ministerio da Clencla e Toenologia, associada Universidado de Sto Paulo. 